\title{
DIVERSIDADE DE NEMATÓIDES EM ÁREAS DE VEGETAÇÃO NATIVA E CULTIVADA EM SÃO CARLOS, ESTADO DE SÃO PAULO, BRASIL
}

\section{ALEXANDRE MOURA CINTRA GOULART}

Engenheiro Agrônomo

Orientador: Prof. Dr. LUIZ CARLOS CAMARGO BARBOSA FERRAZ

Tese apresentada à Escola Superior de Agricultura "Luiz de Queiroz", Universidade de São Paulo, para obtenção do título de Doutor em Agronomia, Área de Concentração: Fitopatologia.

PIRACICABA

Estado de São Paulo - Brasil

Novembro - 2002 


\section{Dados Internacionais de Catalogação na Publicaçāo (CIP) DIVISÃO DE BIBLIOTECA E DOCUMENTAÇÃO - ESALQ/USP}

\section{Goulart, Alexandre Moura Cintra}

Diversidade de nematóides em áreas de vegetaçāo nativa e cultivada em Sāo Carlos, Estado de São Paulo, Brasil / Alexandre Moura Cinta Goulart. - - Piracicaba, 2002.

151 p. : il.

Tese (doutorado) - Escola Superior de Agricultura Luiz de Queiroz, 2002.

Bibliografia.

1. Biodiversidade 2. Fauna edáfica 3. Nematóides 4. Planta cultivada 5. Planta nativa 6. São Carlos I. Título

CDD 595.13 
“... pois que teu Deus te ajuda."

(I Crônicas 12.18, Bíblia)

A Deus, com louvor, DEDICO.

À Flávia, minha querida esposa,

OFEREÇO. 


\section{AGRADECIMENTOS}

Gostaria de expressar meu reconhecimento a todos que contribuíram para a realização deste trabalho, agradecendo em especial:

Ao Prof. Dr. Luiz Carlos Camargo Barbosa Ferraz, pela orientação e estímulo constante.

Ao Prof. Dr. Ailton Rocha Monteiro, pela colaboração e ensinamentos, especialmente no tocante às identificações taxonômicas.

Ao Prof. Dr. Carlos Roberto Sousa e Silva, por possibilitar coletas de amostras em área da Universidade Federal de São Carlos.

Ao Técnico Agrícola Sr. Cândido Ransani, por possibilitar coletas de amostras em área da Fazenda Itaguassu em São Carlos.

Ao Dr. Joaquim Bartolomeu Rassini, por possibilitar coletas de amostras em área da EMPRAPA-Pecuária Sudeste em São Carlos.

Ao Dr. Cássio van den Berg (Kew Garden, Reino Unido) e ao Dr. Alexander

Turra (Universidade Estadual de Campinas, UNICAMP), especialistas em ecologia, pela colaboração na parte de análise de dados.

À Fundação de Amparo à Pesquisa do Estado de São Paulo (FAPESP), pela concessão de bolsa de estudo. 


\section{SUMÁRIO}

Página

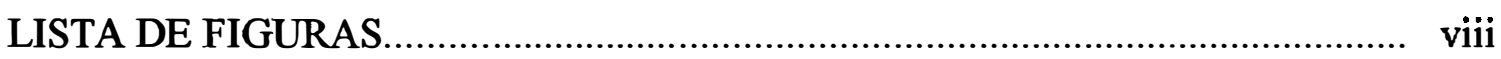

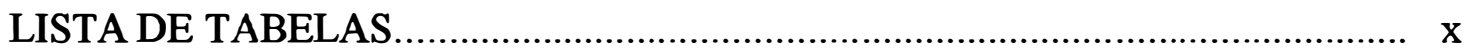

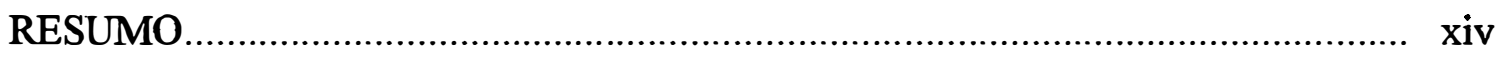

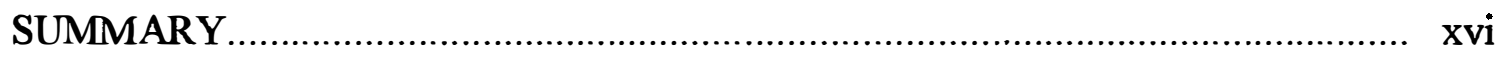

1 INTRODUÇÃO

2 REVISÃO DE LITERATURA............................................................... 3

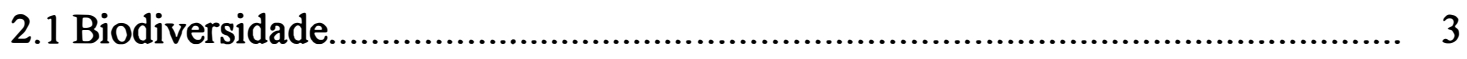

2.2 Diversidade da fauna do solo........................................................................ 5

2.3 Diversidade e hábitos alimentares de nematóides............................................... 7

2.4 Importância de nematóides de vida livre em processos ecológicos do solo........ 9

2.5 Análise de dados em estudos de diversidade ................................................ 12

2.6 Estudos de diversidade de nematóides...................................................... 14

2.6.1 Estudos em ecossistemas naturais............................................................. 15

2.6.2 Estudos em agroecossistemas............................................................... 16

2.6.3 Estudos em ecossistemas naturais e agroecossistemas................................... 18 


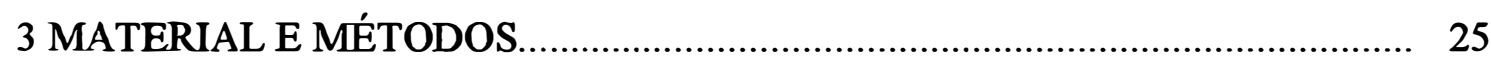

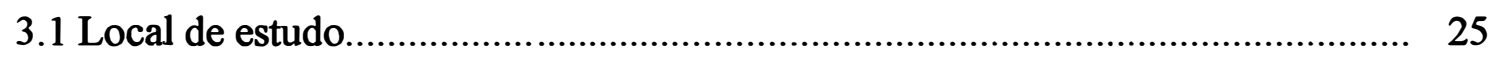

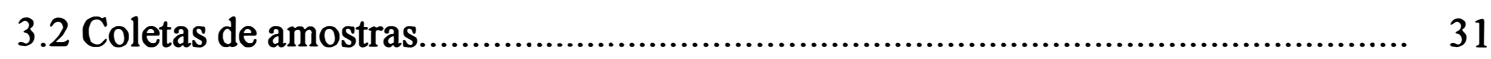

3.3 Extração de nematóides............................................................................ 34

3.4 Identificações e abundâncias de taxa ............................................................ 34

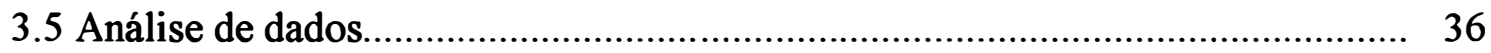

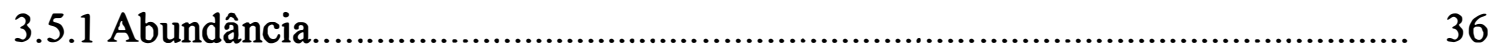

3.5.1.1 Abundância absoluta....................................................................... 36

3.5.1.2 Abundância relativa........................................................................ 36

3.5.2 Frequêencia de ocorrência de taxa............................................................ 37

3.5.2.1 Freqüência absoluta......................................................................... 37

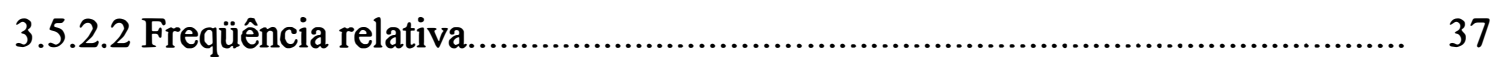

3.5.3 Valor de proeminência........................................................................ 37

3.5.3.1 Valor de proeminência absoluto............................................................ 37

3.5.3.2 Valor de proeminência relativo.............................................................. 38

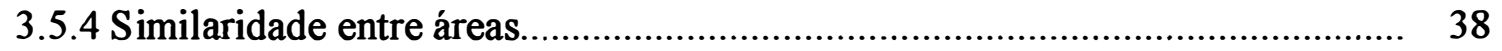

3.5.4.1 Índice de similaridade de Jaccard........................................................ 38

3.5.4.2 Índice de similaridade de Bray \& Curtis ................................................ 39

3.5.5 Medidas de diversidade ........................................................................ 39

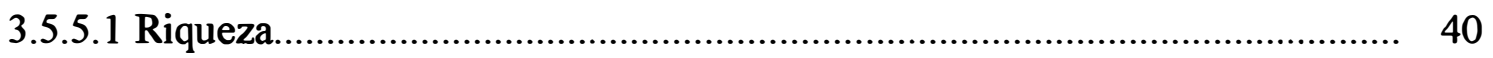

3.5.5.2 Índice de Shannon-Weaver................................................................. 40

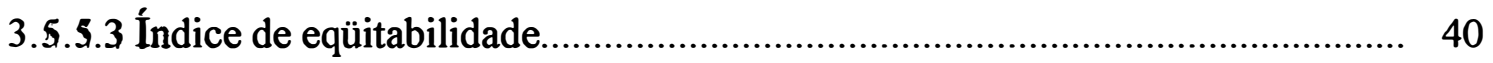

3.5.6 Hábitos alimentares............................................................................. 41

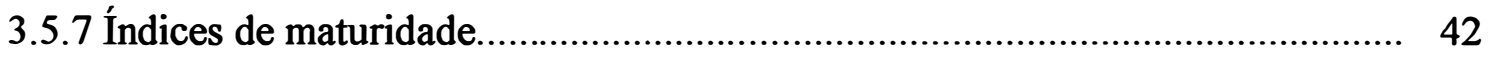

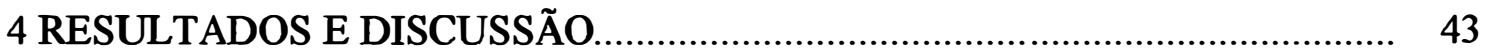

4.1 Posição sistemática dos nematóides encontrados................................................ 43

4.2 Identificações taxonômicas..................................................................... 50

4.3 Abundâncias, freqüências e valores de proeminência.........................................60

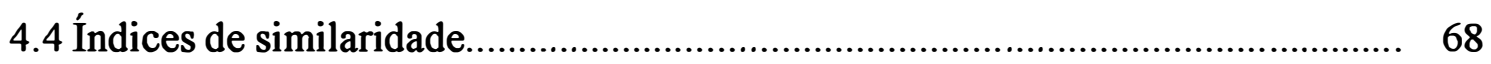


4.5 Medidas de diversidade.

72

4.5.1 Números de toxa enconłrados em relação ao número de amostras coletadas... 72

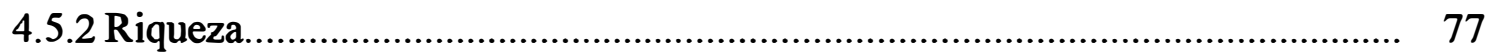

4.5.3 Índice de Shannon-Weaver...................................................................... 79

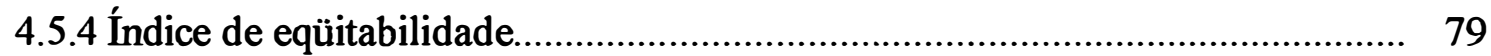

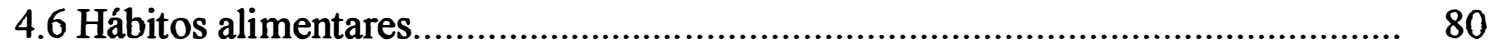

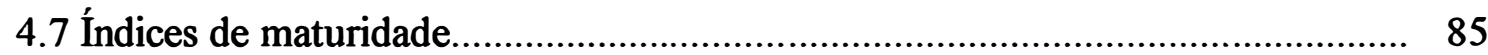

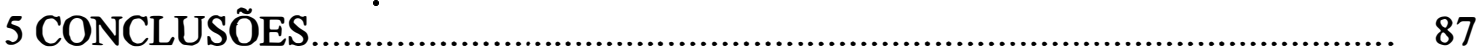

ANEXOS

REFERÊNCIAS BIBLIOGRÁFICAS....................................................... 114

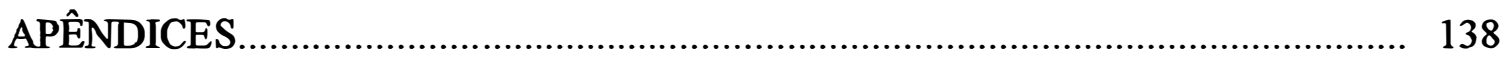




\section{LISTA DE FIGURAS}

Página

1 Localização das áreas de amostragens para estudo de diversidade de nematóides em São Carlos, SP. 1- Universidade Federal de São Carlos ( $\square$ cerrado); 2Fazenda Itaguassu ( $\Delta$ goiabal); 3- EMBRAPA-Pecuária Sudeste ( $O$ milharal). Fonte: Prefeitura Municipal de São Carlos.

2 Área de vegetação nativa (cerrado "strictu sensu") em São Carlos (SP), da reserva de preservação da Universidade Federal de São Carlos, utilizada para estudo de diversidade de nematóides.

3 Área de goiabal da Fazenda Itaguassu, em São Carlos (SP), utilizada para estudo de diversidade de nematóides.

4 Área de milharal da EMBRAPA - Pecuária Sudeste, em São Carlos (SP), utilizada para estudo de diversidade de nematóides.

5 Números acumulados de famílias de nematóides em relação ao número de amostras de solo coletadas em áreas de cerrado, goiabal e milharal em São Carlos, SP (amostragens realizadas em maio de 1999 e fevereiro de 2000) 
6 Números acumulados de gêneros de nematóides em relação ao número de amostras de solo coletadas em áreas de cerrado, goiabal e milharal em São Carlos, SP (amostragens realizadas em maio de 1999 e fevereiro de 2000)

7 Números acumulados de famílias de nematóides em relação ao número de amostras de raízes coletadas em áreas de cerrado, goiabal e milharal em São Carlos, SP (amostragens realizadas em maio de 1999 e fevereiro de 2000)

8 Números acumulado de gêneros de nematóides em relação ao número de amostras de raízes coletadas em áreas de cerrado, goiabal e milharal em São Carlos, SP (amostragens realizadas em maio de 1999 e fevereiro de 2000)

9 Abundâncias relativas (\%) de nematóides dos hábitos alimentares fitoparasito (F), bacteriófago (B), micófago $(M)$, bacteriófago ou micófago $(B+M)$, predador $(\mathrm{P})$, onívoro $(\mathrm{O})$, predador ou onívoro $(\mathrm{P}+\mathrm{O})$, nas áreas de amostragem em São Carlos, SP (médias de 10 amostras de solo para cada área). Letras distintas (em cada hábito alimentar) indicam diferenças significativas pelo teste de Duncan a 5\%, com dados transformados para arco seno da raiz quadrada de $\mathrm{x} / 100$. A) amostragem em maio de 1999; B) amostragem em fevereiro de 2000 


\section{LISTA DE TABELAS}

Página

1 Estudos de diversidade de nematóides com amostragem apenas em

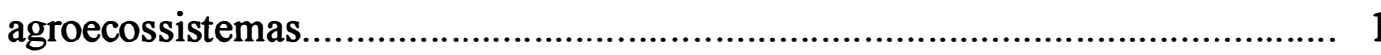

2 Análises granulométricas de solo das três áreas de amostragem em São Carlos (SP).

3 Análises químicas de solo das três áreas de amostragem em São Carlos (SP).

4 Análises químicas de micronutrientes de solo das três áreas de amostragem em São Carlos (SP).

5 Dados climáticos mensais de temperaturas máximas (Tmáx), temperaturas mínimas (Tmín), temperaturas médias (Tmédia) e precipitação pluviométrica (Pp) em São Carlos (SP), obtidos durante os anos em que foram realizadas coletas de amostras de solo e raízes para estudo de diversidade de nematóides

6 Identificações taxonômicas de nematóides presentes em amostras coletadas em área de cerrado em São Carlos, SP (amostragens em maio de 1999 e fevereiro de 2000). 
7 Identificações taxonômicas de nematóides presentes em amostras coletadas em área de goiabal em São Carlos, SP (amostragens em maio de 1999 e fevereiro de 2000)

8 Identificações taxonômicas de nematóides presentes em amostras coletadas em área de milharal em São Carlos, SP (amostragens em maio de 1999 e fevereiro de 2000)

9 Abundâncias absolutas de taxa de nematóides que possibilitaram distinção entre as áreas de cerrado, goiabal e milharal em São Carlos, SP (amostragem em maio de 1999; médias de 10 amostras de solo+raízes).

10 Abundâncias absolutas de toxa de nematóides que possibilitaram distinção entre as áreas de cerrado, goiabal e milharal em São Carlos, SP (amostragem em fevereiro de 2000; médias de 10 amostras de solo+raízes).

11 Índices de similaridade de Jaccard para comparações de fauna nematológica entre áreas em São Carlos, SP, com base em famílias ocorrentes em amostras de solo e raízes (amostragens realizadas em maio de 1999 e fevereiro de 2000)

12 Índices de similaridade de Jaccard para comparações de fauna nematológica entre áreas em São Carlos, SP, com base em gêneros identificados em amostras de solo e raízes (amostragens realizadas em maio de 1999 e fevereiro de 2000).

13 Índices de similaridade de Bray \& Curtis para comparações de fauna nematológica entre áreas em São Carlos, SP, com base em famílias ocorrentes em amostras de solo (amostragem realizada em maio de 1999). 
14 Índices de similaridade de Bray \& Curtis para comparações de fauna nematológica entre áreas em São Carlos, SP, com base em gêneros identificados em amostras de solo (amostragem realizada em maio de 1999)... 71

15 Índices de similaridade de Bray \& Curtis para comparações de fauna nematológica entre áreas em São Carlos, SP, com base em famílias ocorrentes em amostras de solo (amostragem realizada em fevereiro de 2000).

16 Índices de similaridade de Bray \& Curtis para comparações de fauna nematológica entre áreas em São Carlos, SP, com base em gêneros identificados em amostras de solo (amostragem realizada em fevereiro de 2000).

17 Riquezas (ou números) de famílias de nematóides presentes em amostras de solo coletadas em áreas de cerrado, goiabal e milharal em São Carlos, SP (amostragens em maio de 1999 e fevereiro de 2000).

18 Riquezas (ou números) de gêneros de nematóides identificados em amostras de solo coletadas em áreas de cerrado, goiabal e milharal em São Carlos, SP (amostragens em maio de 1999 e fevereiro de 2000).

19 Riquezas (ou números) de famílias de nematóides presentes em amostras de raízes coletadas em áreas de cerrado, goiabal e milharal em São Carlos, SP (amostragens em maio de 1999 e fevereiro de 2000).

20 Riquezas (ou números) de gêneros de nematóides identificados em amostras de raízes coletadas em áreas de cerrado, goiabal e milharal em São Carlos, SP (amostragens em maio de 1999 e fevereiro de 2000). 
21 Índices de diversidade de Shannon-Weaver ( $\left.\mathrm{H}^{\prime}\right)$ das comunidades de nematóides no solo das áreas de amostragem em São Carlos, SP (calculado com base na diversidade de famílias de nematóides; médias de 10 amostras de solo para cada área e época de amostragem)

22 Índices de eqüitabilidade (J') das comunidades de nematóides no solo das áreas de amostragem em São Carlos, SP (calculado com base na diversidade de famílias de nematóides; média de 10 amostras de solo para cada área e época de amostragem)

23 Índices de diversidade trófica $(\mathrm{T})$ das comunidades de nematóides nas áreas de amostragem em São Carlos, SP (médias de 10 amostras de solo para cada época de amostragem).

24 Índices de maturidade modificados (IMm), índices de maturidade (IM) e índices de parasitos de plantas (IPP) para as áreas de estudo da fauna nematológica em São Carlos, SP (amostragens realizadas em 1999 e 2000; médias de 10 amostras para cada área e época de amostragem). 


\title{
DIVERSIDADE DE NEMATÓIDES EM ÁREAS DE VEGETAÇÃO NATIVA E CULTIVADA EM SÃo CARLOS, ESTADO DE SÃO PAULO, BRASIL
}

\author{
Autor: ALEXANDRE MOURA CINTRA GOULART \\ Orientador: Prof. Dr. LUIZ CARLOS CAMARGO BARBOSA FERRAZ
}

\section{RESUMO}

Realizou-se estudo de comunidades de nematóides em três áreas situadas em São Carlos, Estado de São Paulo: área de vegetação nativa de cerrado, área de cultura perene (goiabeira, Psidium guajava L.) e área de cultura anual (milho, Zea mays L.). Os objetivos foram: $1^{\underline{0}}$ ) contribuir para o conhecimento da diversidade de nematóides (fitoparasitos ou de vida livre) em áreas de vegetação nativa e cultivada; $2^{\circ}$ ) estudar a influência de atividades agrícolas nas comunidades de nematóides. Para tanto, foram feitas duas amostragens (maio de 1999 e fevereiro de 2000). Em cada amostragem, foram coletadas dez amostras compostas de solo+raízes em cada área. Após a extração de nematóides das amostras, foram realizadas identificações taxonômicas e contagens de exemplares em câmara de Peters para determinação das densidades ou abundâncias de cada taxon. Nematóides fitoparasitos foram identificados até nível de gênero ou espécie e os de vida livre até nível de família ou gênero. Os dados foram analisados com base nos seguintes parâmetros: abundância, freqüência, valor de proeminência, índices de similaridade (Jaccard e Bray \& Curtis), riqueza, índices de diversidade (Shannon-Weaver e eqüitabilidade), índice de diversidade trófica, abundâncias relativas de grupos tróficos e índices de maturidade. $O$ gênero mais abundante em cerrado foi Discocriconemella e nas áreas cultivadas foi Helicotylenchus. Em geral, os nematóides 
mais abundantes também apresentaram as maiores freqüências $e$ valores de proeminência, com algumas exceções. Foi possível concluir que a retirada da vegetação nativa de cerrado e a implantação dos cultivos de goiabeira e milho influenciaram as comunidades de nematóides nas áreas amostradas, resultando em: redução na abundância da superfamília Criconematoidea e da família Criconematidae, bem como ausência de Discocriconemella e Tylenchulus (todos grupos taxonômicos muito abundantes na vegetação original de cerrado); elevação nas abundâncias de Helicotylenchus e Pratylenchus; menores valores de riqueza de gêneros, diversidade trófica e abundância relativa de nematóides predadores ou onívoros. A similaridade com a área de cerrado foi menor quando o cultivo estabelecido foi o de milho. Especialmente em relação ao cultivo de milho, ocorreu: redução na abundância de Dorylaimellus e ausência de Dorylaimoides e Labronema (todos gêneros muito abundantes na vegetação original de cerrado). 


\title{
NEMATODE DIVERSITY IN NATIVE AND CULTIVATED VEGETATION IN SÃo CARLOS, STATE OF SÃO PAULO, BRAZIL
}

\author{
Author: ALEXANDRE MOURA CINTRA GOULART \\ Adviser: Prof. Dr. LUIZ CARLOS CAMARGO BARBOSA FERRAZ
}

\section{SUMMARY}

A community study of nematodes was done in three areas placed in São Carlos, State of São Paulo: native vegetation of "cerrado", perennial crop (guava, Psidium guajava L.) and annual crop (corn, Zea mays L.). The objectives were: $1^{\text {st }}$ ) to contribute for the knowledge of nematode diversity (plant-parasitic and free-living); $2^{\text {nd }}$ ) to study the influence of agricultural activities on nematode communities. For that, two samplings were made (May of 1999 and February of 2000). In each sampling, ten composite samples of soil+roots were collected in each area. After nematode extraction, individuals were classified into taxonomic groups and counted in Peters slide for determination of densities or abundances of each toxon. Plant-parasitic nematodes were classified at the genus or species level whereas free-living forms were classified at the family or genus level. The data were analyzed with the following parameters: abundance, frequency, proeminence value, similarity indexes (Jaccard and Bray \& Curtis), richness, diversity indexes (Shannon-Weaver and evenness), trophic diversity index, relative abundance of trophic groups and maturity indexes. The most abundant genus in "cerrado" was Discocriconemella and in cultivated areas was Helicotylenchus. In general, the most abundant nematodes also had the greatest frequencies and proeminence values, with some exceptions. It was possible to conclude that the 
replacement of the native vegetation of "cerrado" with guava and corn crops influenced nematode communities in the sampled areas, resulting in: reduction in abundance of superfamily Criconematoidea and family Criconematidae, as well as absence of Discocriconemella and Tylenchulus (taxonomic groups very abundant in the original vegetation of "cerrado"); greater abundances of Helicotylenchus and Pratylenchus, decreased values of richness of genera, trophic diversity and relative abundance of predators or omnivorous nematodes; less similarity with "cerrado" when com was the crop established. Corn cultivation resulted in reduction in abundance of Dorylaimellus and absence of Dorylaimoides and Labronema (genera very abundant in original vegetation of "cerrado"). 


\section{INTRODUÇÃO}

Segundo Wilson (1994), um plano básico para utilizar em perpetuidade o máximo possível da biodiversidade da Terra passa, prioritariamente, por recenseamentos da fauna e da flora mundial, com base em levantamentos e estudos taxonômicos. Por outro lado, existe atualmente grande necessidade de formação de taxonomistas, em diversas áreas e em especial em Nematologia, para que o desafio de se estudar a biodiversidade possa ser superado com sucesso. A taxonomia, pré-requisito para estudos de biodiversidade, exige muito pessoal, com formação e treinamento especializados. Segundo o mesmo autor, provavelmente há no máximo 1500 taxonomistas profissionais treinados com competência para lidar com organismos tropicais, isto é, com mais da metade da biodiversidade do mundo. Assim, um recenseamento completo das vastas reservas de diversidade biológica da Terra pode parecer um empreendimento inatingível, com tão poucas pessoas para levá-lo a cabo.

Uma área promissora para pesquisa ecológica é o estudo da biodiversidade em solos, agrícolas ou não. Agroecossistemas são geralmente estabelecidos como monoculturas e práticas de manejo associadas resultam em modificações na estrutura do solo, que, por sua vez, causam maiores flutuações de umidade e temperatura, em relação a áreas não cultivadas. Os instáveis habitats resultantes inibem o estabelecimento e a permanência de muitos nematóides. A agricultura favorece alguns nematóides que são capazes de sobreviver e reproduzir em um ambiente de freqüentes mudanças, inclusive em relação a fontes de alimento. Portanto, comunidades de nematóides em agroecossistemas geralmente apresentam diversidades mais baixas que em áreas naturais (Norton \& Niblack, 1991). 
Grande parte dos trabalhos de pesquisa sobre diversidade de nematóides no Brasil ainda limita-se à realização de identificações taxonômicas, sem considerar as abundâncias, ou seja, números de indivíduos de cada toxon. No entanto, sabe-se que a medida de diversidade biológica é obtida apropriadamente a partir de dados qualitativos (identificações taxonômicas) e quantitativos (abundâncias), para que organismos de ocorrência rara ou comum não sejam considerados igualmente. Além disso, a maioria dos estudos no Brasil restringe-se a nematóides fitoparasitos encontrados em áreas cultivadas. Portanto, há necessidade de se incluir com mais freqüência os nematóides de vida livre nos estudos, como também amostragem em áreas de vegetação nativa.

O presente trabalho é um estudo sinecológico, sendo que as comunidades foram estudadas levando em consideração os nematóides presentes em amostras de solo e raízes coletadas em três áreas situadas em São Carlos, Estado de São Paulo: área de vegetação nativa (cerrado "strictu sensu", conforme conceituação de Coutinho, 1978), área de cultura perene (goiabeira, Psidium guajava L.) e área de cultura anual (milho, Zea mays L.). $\mathrm{O}$ objetivo geral do trabalho foi contribuir para o conhecimento da diversidade de nematóides (fitoparasitos ou não) em áreas de vegetação nativa e cultivada. Considerando que todas as áreas amostradas possuem mesmo tipo de solo (latossolo vermelho-amarelo) e as áreas cultivadas localizam-se sobre solo anteriormente coberto com a vegetação original de cerrado "strictu sensu", o trabalho teve também o objetivo específico de estudar a influência de atividades agrícolas nas comunidades de nematóides. 


\section{REVISÃO DE LITERATURA}

\subsection{Biodiversidade}

Ecologia é o estudo da estrutura e função da natureza (Odum, 1973). Outra definição, enfatizando a dinâmica de populações, apresenta a ecologia como o estudo das interações que determinam a distribuição e abundância de organismos na natureza (Krebs, 1994). Existem dois tipos de pesquisa ecológica: autoecológica e sinecológica. Autoecologia é o estudo de uma única espécie em relação ao ambiente, o qual inclui outros organismos e fatores abióticos. Sinecologia, ou ecologia de comunidade, é o estudo simultâneo de várias espécies em relação ao ambiente (Jongman et al., 1995). Uma população é um conjunto de indivíduos de uma mesma espécie. Uma comunidade é um conjunto de populações em uma determinada área ou habitat (Krebs, 1994).

A diversidade biológica ou biodiversidade pode ser definida como a diversidade da vida em todas as suas formas e níveis de organização. A biodiversidade existe pelo menos em cada um dos seguintes níveis: genes, espécies (ou outras categorias taxonômicas) e ecossistemas. Assim, a diversidade pode ser genética, taxonômica ou de ecossistemas, de acordo com o nível de organização considerado (Hunter Jr., 1999).

A diversidade taxonômica pode ser definida como o número de espécies de um determinado taxon ou o número de taxa na comunidade (Norton, 1978). De fato, o número de espécies ou taxa na comunidade é o mais antigo e mais simples conceito de diversidade, sendo chamado de "riqueza de espécies", "riqueza de taxa" ou, simplesmente, "riqueza". Um problema em utilizar somente a riqueza como medida de diversidade é que as espécies de ocorrência rara ou comum são consideradas igualmente. Portanto, o conceito de diversidade deve incluir também outro componente: a heterogeneidade, que está relacionada ao número de indivíduos de cada taxon, ou seja, à 
densidade ou abundância de cada toxxon. A heterogeneidade pode ser alternativamente chamada de uniformidade ou eqüitabilidade (Krebs, 1989; 1994; Magurran, 1988; Norton, 1978).

A diversidade trófica (relacionada aos hábitos alimentares dos organismos) e a diversidade funcional (relacionada às funções ecológicas dos organismos) constituem outros enfoques para a biodiversidade, muito úteis para a compreensão dos processos ecológicos em comunidades e ecossistemas, especialmente quando avaliadas juntamente com a diversidade taxonômica (Bongers \& Bongers, 1998; Freckman \& Ettema, 1993).

A diversidade biológica possui vários componentes, dois dos quais são chamados de diversidade alfa (ou local) e diversidade gama (ou regional). A diversidade local está relacionada com pequenas áreas de habitat mais ou menos uniforme, enquanto que a diversidade regional está relacionada com todos os habitats que são encontrados em uma determinada região. A diversidade beta refere-se à troca de organismos de um habitat para outro adjacente ou próximo (Ricklefs, 1996).

A relação entre biodiversidade e estabilidade na comunidade ainda é uma área obscura da ciência. Porém, pode-se afirmar que a eliminação de uma determinada espécie, denominada "espécie-chave", causa o fim de outras espécies, possivelmente de maneira tão intensa que alteraria a estrutura fisica do próprio habitat. Como a ecologia ainda é uma ciência primitiva, não se conhece ao certo a identidade da maioria das espécies-chaves. É comum pensar que os organismos dessa categoria vital são sempre de grande porte, mas ela pode muito bem incluir qualquer um dos minúsculos invertebrados (Hunter Jr., 1996; Norton, 1988; Wilson, 1994). Quando se avalia o papel ou função ecológica das espécies, pesquisadores da área de conservação biológica em geral assumem a idéia de que qualquer componente do ecossistema é importante, até que se prove o contrário (Ehrenfeld, 1988; Ehrlich \& Mooney, 1983; Norton, 1988). O atual conhecimento de ecossistemas é ainda tão limitado que seria insensato não adotar essa posição. Além disso, uma espécie atualmente considerada relativamente pouco importante pode tornar-se mais importante à medida que o ecossistema sofra modificações com o tempo (Hunter Jr., 1996). 
Uma área promissora para pesquisa ecológica é o estudo da biodiversidade em solos, agrícolas ou não. Os solos são ecossistemas complexos com uma enorme variedade de plantas, minúsculos animais e microrganismos reunidos em delicado equilíbrio, fazendo nutrientes circularem sob a forma de soluções e partículas. $\mathrm{O}$ equilíbrio microscópico dos solos sustenta os ecossistemas naturais e os agroecossistemas (Wilson, 1994).

\subsection{Diversidade da fauna do solo}

Os animais que fazem parte da biota do solo são muito numerosos e diversos. $\mathrm{O}$ número de espécies é muito grande, incluindo representantes de todos os filos terrestres (Coleman \& Crossley, 1996). Muitos grupos são bem pouco conhecidos taxonomicamente. Estudos de biodiversidade em ecossistemas devem incluir organismos de solo (Hawksworth \& Ritchie, 1993; Wall et al., 2001).

Numerosos pesquisadores têm destacado a grande variação em tamanho do corpo dos organismos da fauna do solo. Uma classificação generalizada por comprimento do corpo ilustra uma forma comum de separar a fauna do solo em classes de tamanho: microfauna, mesofauna e macrofauna (e, às vezes, megafauna). Essa classificação compreende a faixa de variação desde o menor ao maior, por exemplo, desde um microflagelado de 1-2 $\mu \mathrm{m}$ até uma minhoca gigante australiana de vários metros. É possível também classificar a fauna do solo com base na largura do corpo. A largura do corpo de um organismo está relacionada com seu microhabitat. A microfauna habita os filmes de água do solo, grupo no qual estão incluídos os nematóides. A mesofauna habita os poros preenchidos com ar e dependem da existência desses poros. A macrofauna, por outro lado, tem a habilidade de criar seus próprios espaços por meio de atividades escavadoras e, como a megafauna, pode ter grande influência na estrutura do solo. Existe, naturalmente, considerável gradação na classificação baseada na largura do corpo. $\mathrm{O}$ menor organismo da mesofauna exibe características da microfauna e assim por diante. Apesar disso, essa classificação com base na largura do corpo tem sido a mais amplamente utilizada (Coleman \& Crossley, 1996). 
Todos os componentes da biota possuem importantes papéis em processos do solo, como sumariado no Quadro 1.

\begin{tabular}{|l|l|l|}
\hline & Ciclagem de nutrientes & Estrutura do solo \\
\hline Macrofauna & $\begin{array}{l}\text { Fragmenta os resíduos vegetais. } \\
\text { Estimula atividade microbiana. }\end{array}$ & $\begin{array}{l}\text { Mistura particulas orgânicas e minerais. } \\
\text { Redistribui a matéria orgânica e } \\
\text { microbiota. } \\
\text { Cria "bioporos". } \\
\text { Promove humificação. } \\
\text { Produz coprólitos. }\end{array}$ \\
\hline Mesofauna & $\begin{array}{l}\text { Regula populações de fungos e da } \\
\text { microfauna. } \\
\text { Favorece a mineralização mais } \\
\text { rápida de nutrientes. }\end{array}$ & $\begin{array}{l}\text { Produz coprólitos. } \\
\text { Cria "bioporos". } \\
\text { Promove humificação. }\end{array}$ \\
\hline Microfauna & $\begin{array}{l}\text { Regula populações da microbiota. } \\
\text { Favorece a mineralização mais } \\
\text { rápida de nutrientes. }\end{array}$ & $\begin{array}{l}\text { Pode afetar a estrutura de agregados por } \\
\text { meio de interações com a microbiota. }\end{array}$ \\
\hline Microbiota & $\begin{array}{l}\text { Decompõe a matéria orgânica. } \\
\text { Mineraliza e imobiliza nutrientes. }\end{array}$ & $\begin{array}{l}\text { Produz compostos que ligam os } \\
\text { agregados. } \\
\text { Hifas enredam partículas em agregados. }\end{array}$ \\
\hline
\end{tabular}

Quadro 1- Influências da biota em processos do solo. Adaptado de Coleman \& Crossley (1996).

A mesofauna e macrofauna produzem coprólitos e "bioporos" de vários tamanhos, que afetam o movimento e armazenamento da água, assim como o crescimento radicular. Muitos organismos da macrofauna, especialmente minhocas, formigas e cupins, são conhecidos como "engenheiros do solo", pois modificam o ambiente por suas atividades mecânicas. Um outro efeito da mesofauna e macrofauna, que talvez seja mais importante, considerando um longo período de tempo, é o favorecimento da humificação. A fragmentação de restos vegetais realizada pela meso e macrofauna aumenta a área disponível para o posterior ataque da microbiota. A microfauna apresenta suas principais influências em interações com a microbiota (Coleman \& Crossley, 1996; Wolters, 2000). Nematóides do solo são considerados integrantes da microfauna (ou pequenos integrantes da mesofauna), uma vez que exemplares das espécies maiores em geral não excedem $10 \mathrm{~mm}$ e a maioria é menor que $1 \mathrm{~mm}$ de comprimento (Bernard, 1992). 


\subsection{Diversidade e hábitos alimentares de nematóides}

Entre os animais multicelulares, os nematóides são os mais abundantes. Constituem um grupo muito diverso, pertencendo a um filo próprio: Nemata (ou Nematoda), como foi proposto primeiro por Cobb, em 1919, e restabelecido por Chitwood, em 1958 (Maggenti, 1981).

Os nematóides ocupam os habitats mais variados que os de qualquer outro grupo de metazoários, salvo os artrópodos. São considerados organismos aquáticos, podendo viver em águas marinhas, águas doces ou películas de água do solo (Ferraz \& Monteiro, 1995). A movimentação dos nematóides no solo ocorre entre as partículas, no filme de água. $\mathbf{O}$ tamanho dos poros ou interstícios permitem uma movimentação mais dinâmica dos nematóides; quando eles são de diâmetro maior que o corpo dos nematóides, transformam-se, com auxílio da umidade, em canais por onde o nematóides se movimentam no solo (Tihohod, 1993).

A maioria dos nematóides é de vida livre, alimentando-se de microrganismos, tais como bactérias (bacteriófagos), fungos (micetófagos ou micófagos), algas (algívoros), protozoários (protozoófagos). Entre os nematóides de vida livre, existem também aqueles que se alimentam de seres que não são considerados microrganismos. Nesse caso, há nematóides que se alimentam de pequenas minhocas ou oligoquetas, tardígrados, rotíferos ou outros nematóides. Alguns são parasitos de plantas superiores (fitoparasitos), principalmente de seus órgãos subterrâneos (raízes, rizomas, tubérculos, bulbos ou fruto hipógeo), também existindo os que passaram a parasitos de órgãos aéreos (caules, folhas, frutos e sementes). Outros são parasitos de animais (zooparasitos), de invertebrados ou vertebrados (Ferraz \& Monteiro, 1995).

Os nematóides de solo podem ser classificados em grupos tróficos, com base em seus hábitos alimentares, como proposto por Yeates et al. (1993). De acordo com esses autores, os principais grupos tróficos são: fitoparasitos (ou fitófagos); micófagos; bacteriófagos; predadores; onívoros.

A morfologia da região anterior e cavidade bucal do nematóide está relacionada com seu hábito alimentar. Nematóides fitoparasitos apresentam estilete, o qual pode ser do tipo estomatostílio ou odontostílio. Porém, nem todos nematóides que possuem 
estilete são fitoparasitos. Existem nematóides portadores de estilete que são micófagos; outros são predadores ou onívoros. Portanto, a presença do estilete é condição necessária, mas não suficiente para o fitoparasitismo. Os nematóides bacteriófagos mais comuns no solo apresentam cavidade bucal cilíndrica, estreita. Nematóides com cavidade bucal ampla, globosa, armada com dentes, dentículos e/ou placas cortantes são predadores de pequenos animais do solo, inclusive outros nematóides.

Nematóides micófagos realizam alimentação, primeiramente, penetrando o estilete em uma célula de uma hifa. Em seguida, através do estilete injetam enzimas responsáveis pela digestão extra-oral do conteúdo celular. Esse conteúdo é então ingerido pelo nematóide (Croll \& Matthews, 1977). Esse modo de alimentação é semelhante ao dos fitoparasitos. De fato, alguns nematóides portadores de estilete podem utilizar, como fonte de alimento, raízes, pelos radiculares ou hifas de fungos (Yeates \& Coleman, 1982). Existem certos gêneros de nematóides que congregam espécies micófagas e fitoparasitas, como Aphelenchoides e Ditylenchus.

A forma mais simples de alimentação entre os nematóides é encontrada nos bacteriófagos. Eles simplesmente ingerem células bacterianas vivas através da cavidade bucal, geralmente cilíndrica e estreita. Esses nematóides, comumente encontrados em matéria orgânica em decomposição, colocam para o interior do organismo, via cavidade bucal, o material liqüefeito resultante da decomposição, embora as bactérias associadas a esse material sejam a real fonte de alimento (Wallwork, 1970).

Todos os nematóides, parasitos ou de vida livre, alimentam-se de organismos vivos. Nematóides que se alimentam de microrganismos podem ser chamados de microbiófagos ou microbiotróficos. Esses nematóides são chamados às vezes de sapróbios ou saprófitas, mas esses termos estão incorretos, uma vez que dão a idéia de que os nematóides obtém alimento de matéria orgânica morta (ou em decomposição), o que na realidade não ocorre. A verdadeira fonte de alimento são os microrganismos, como bactérias e fungos (Ferraz \& Monteiro, 1995; Poinar Jr., 1983).

Nematóides predadores (às vezes chamados de "carnívoros") alimentam-se principalmente de pequenos animais do solo (invertebrados), como protozoários, rotíferos, tardígrados, anelídeos ou mesmo outros nematóides. Quando a cavidade bucal 
é ampla, geralmente armada com dentes e/ou dentículos, nematóides predadores são capazes de ingerir a presa por inteiro (ou parte dela), embora normalmente rasguem a parede do corpo da presa para em seguida ingerir o conteúdo. Representantes desse grupo ocorrem nas ordens Rhabditida, Mononchida, Dorylaimida, Enoplida, Chromadorida e Monhysterida. Quando a cavidade bucal apresenta um estilete relativamente estreito, o nematóide penetra o estilete no interior do corpo da vítima e seu conteúdo é sugado através desse estilete. Representantes desse último grupo ocorrem nas ordens Tylenchida (subordem Aphelenchina) e Dorylaimida (Freckman \& Caswell, 1985; Poinar Jr., 1983; Small, 1987; Yeates, 1998; Yeates et al., 1993).

Os hábitos alimentares relacionados com os nematóides onívoros são pouco conhecidos. Aparentemente, esses nematóides podem se comportar como: algívoros; predadores; bacteriófagos; micófagos; fitófagos ocasionais ou facultativos, em pelos radiculares de plantas (Freckman \& Caswell, 1985).

\subsection{Importância de nematóides de vida livre em processos ecológicos do solo}

Apesar de nematóides serem muito numerosos na maioria dos ecossistemas, a contribuição deles para a respiração no solo é relativamente pequena. Portanto, julgando com base em fluxo de energia, nematóides seriam considerados pouco importantes. Porém, a contribuição de um grupo de organismos para o funcionamento do sistema como um todo não pode ser julgada somente com base na quantidade de energia processada por esse grupo. Nas cadeias alimentares, consumidores como os nematóides podem ser relativamente pouco importantes para o fluxo de energia, mas, por outro lado, podem realizar um papel importante como reguladores de taxas ou velocidades das transformações, como a decomposição da matéria orgânica (Whitford et al., 1982).

As dinâmicas populacionais de nematóides microbiófagos tendem a se sincronizar com aquelas dos microrganismos dos quais esses nematóides se alimentam (Freckman, 1988; Mikola, 1998). Nematóides micófagos e bacteriófagos afetam a atividade de fungos e bactérias, conseqüentemente afetando também a decomposição da matéria orgânica realizada por esses microrganismos. Em variadas condições ambientais, nematóides microbiófagos contribuem direta e indiretamente para o 
processo de decomposição da matéria orgânica, chegando a elevar taxas de mineralização de carbono (respiração) e de outros nutrientes (Anderson et al., 1981; Bardgett \& Chan, 1999; Chen \& Ferris, 1999; De Ruiter et al., 1993; Ferris et al., 1998; Laakso \& Setala, 1999; Mikola \& Setala, 1998; Trofymow et al., 1983). Por exemplo, nematóides bacteriófagos defecam $50-80 \%$ do material consumido, contribuindo de forma direta para a decomposição da matéria orgânica (Trofymow \& Coleman, 1982). É sabido que o principal produto de excreção de nematóides é a amônia (Wright \& Newall, 1976). Porém, sabe-se que o efeito indireto é muito mais importante (Mishra \& Mitchell, 1987; Niles \& Freckman, 1998; Trofymow \& Coleman, 1982). Os prováveis mecanismos pelos quais esse efeito indireto pode ocorrer são: nematóides transportam microrganismos para microhabitats do solo que contém melhores e mais recursos ou fontes de alimento, promovendo assim o aumento no crescimento microbiano; nematóides fornecem excretas e alimento não completamente digeridos como fonte de alimento para microrganismos; nematóides micófagos ingerem hifas senescentes, removendo metabólitos secundários responsáveis pela inibição do crescimento fúngico; nematóides microbiófagos, quando presentes em populações não muito altas, aceleram o crescimento microbiano, quando a alimentação dos nematóides ocorre em nível considerado ótimo (Niles \& Freckman, 1998).

A aceleração do crescimento microbiano, decorrente da alimentação de nematóides em nível considerado ótimo, ocorre por meio da manutenção de microrganismos, especialmente bactérias, na fase logarítmica de crescimento populacional, o que pode aumentar a mineralização de nutrientes (Anderson et al., 1981). A provável explicação para esse fato foi obtida de uma extensão da hipótese de crescimento compensatório de plantas em resposta à herbivoria (Hibert et al., 1981). A partir dessa explicação, entende-se que a alimentação de nematóides microbiófagos, em um nível considerado ótimo (quando as populações desses nematóides não são muito altas), promove um maior crescimento microbiano, como resposta compensatória a essa alimentação. Esse fenômeno também é chamado de efeito regulador dos nematóides sobre as populações microbianas (Niles \& Freckman, 1998). Quando nematóides microbiófagos são muito abundantes, a alimentação dos mesmos pode prejudicar o 
crescimento das populações microbianas. Essa situação, em que a alimentação ocorre em níveis elevados (superiores ao nível ótimo), é considerada de ocorrência pouco provável (Bouwman \& Zwart, 1994).

Outros componentes da biota do solo, como protozoários e microartrópodos, também participam em cadeias alimentares detríticas e influenciam a decomposição, regulando populações microbianas (Bouwman \& Zwart, 1994). Contudo, em experimentos controlados, nematóides foram mais bem sucedidos do que protozoários em explorar baixas populações de bactérias na rizosfera, provavelmente porque somente os nematóides são capazes de migrar no solo e encontrar locais com maiores concentrações de bactérias (Griffiths \& Caul, 1993).

Em trabalhos experimentais desenvolvidos em ecossistemas desérticos nos Estados Unidos, foi possível concluir que nematóides de vida livre aparentemente regulam as taxas de decomposição de matéria orgânica, afetando os processos de ciclagem de nutrientes. Nesses trabalhos, foi verificada a participação de vários organismos na degradação de matéria orgânica. Bactérias e fungos utilizam-se da matéria orgânica, degradando-a, enquanto que ocorrem também nematóides bacteriófagos e micófagos. Esses, por sua vez, são predados por outros organismos, como ácaros ou mesmo outros nematóides. Os resultados indicaram que, em fases iniciais da decomposição, nematóides bacteriófagos possuem um importante papel, mas, em fases posteriores, a decomposição está primariamente relacionada com fungos e nematóides micófagos (Whitford et al., 1982).

Além dos nematóides microbiófagos, o grupo dos predadores também já teve sua importância experimentalmente reconhecida na participação em processos ecológicos do solo. Esses nematóides regulam a mineralização de nutrientes alimentando-se de pequenos animais no solo, inclusive nematóides microbiófagos, constituindo, portanto, um grupo condutor pelo qual os recursos passam para níveis tróficos superiores em cadeias alimentares (Wardle \& Yeates, 1993).

Nematóides podem ser relacionados com a condição ecológica do solo. Qualidade ou sanidade de solos são conceitos relacionados à sustentabilidade da produção agrícola (Doran \& Zeiss, 2000; Herrick, 2000; Neher, 2001; Niles \& 
Freckman, 1998; Saviozzi et al., 2001; Sherwood \& Uphoff, 2000; Xu \& Mage, 2001). Estudos de diversidade de nematóides poderiam ser aplicados para se avaliar a qualidade ou sanidade de solos, inclusive com possibilidades de utilizar nematóides como bio-indicadores na avaliação de impacto de atividades humanas que causam alterações ambientais (Bongers, 1990; Freckman \& Ettema, 1993; Neher, 2001; Neher \& Olson, 1999; Niles \& Freckman, 1998; Porazinska et al., 1999; Yeates \& Bongers, 1999).

O entendimento de sucessão em comunidades de nematóides é um aspecto importante nesse sentido da pesquisa. Nematóides bacteriófagos da família Rhabditidae predominam em fases iniciais da decomposição da matéria orgânica (resíduos recentemente incorporados ao solo, preferencialmente com baixas relações $\mathrm{C} / \mathrm{N}$ ). Com o tempo, espécies de Rhabditidae são substituídas por espécies de Cephalobidae (outros bacteriófagos da mesma ordem, Rhabditida), os quais são mais tolerantes à falta de água e persistem em fases posteriores da sucessão, freqüentemente constituindo a família mais abundante de bacteriófagos em uma comunidade madura (clímax). Nematóides micófagos, como os da subordem Aphelenchina e família Tylenchidae, tornam-se mais proeminentes quando substratos de mais lenta decomposição (como lignina e celulose, com altas relações $\mathrm{C} / \mathrm{N}$ ) acumulam-se no habitat. Nematóides onívoros e predadores, como aqueles das ordens Dorylaimida e Mononchida, estão associados a ambientes estáveis, apresentando maior número de espécies e abundância em comunidades maduras. Por outro lado, muitos estresses ambientais resultam em aumentos nas populações de nematóides fitoparasitos (Niles \& Freckman, 1998).

\subsection{Análise de dados em estudos de diversidade}

O estudo da diversidade em comunidades é desenvolvido apropriadamente a partir de dados qualitativos (identificações taxonômicas) e quantitativos (densidades ou números de indivíduos de cada toxon, ou seja, em terminologia ecológica, abundâncias). A freqüência de ocorrência de um determinado taxon é a razão entre o número de amostras em que esse toxon ocorreu e o número total de amostras coletadas, enquanto que o valor de proeminência de um determinado taxon é uma medida que incorpora em seu cálculo tanto dados de abundância como também de freqüência. Podem ser 
utilizados índices matemáticos para mensuração da diversidade, dos quais os mais comuns e derivados da teoria das probabilidades são o índice de Shannon-Weaver e o índice de eqüitabilidade, sendo que este último expressa em especial a uniformidade (ou eqüitabilidade) entre as abundâncias de diferentes grupos taxonômicos na comunidade. (Norton, 1978; Odum, 1988; Shannon \& Weaver, 1949; Silveira Neto et al., 1976; Southwood, 1968). Para comparação das comunidades entre duas áreas ou tipos de coberturas vegetais podem ser utilizados índices de similaridade, como o de Jaccard e o de Bray \& Curtis (Bray \& Curtis, 1957; Norton, 1978).

Dados de abundâncias relativas (\%) de nematóides de cada grupo trófico ou hábito alimentar são úteis para o estudo de comunidades desses organismos e para a compreensão de suas relações com outros integrantes da biota do solo. Pode-se também utilizar um índice de diversidade trófica (Freckman \& Ettema, 1993).

Um índice de maturidade foi proposto por Bongers (1990), como indicativo da fase de sucessão ecológica em que se encontra uma comunidade de nematóides e como medida de perturbação ou distúrbio do ambiente. Para obtenção desse índice, são considerados "colonizadores" ou "estrategistas-r" nematóides que apresentam rápido aumento populacional em condições favoráveis, possuem ciclo de vida curto, alta capacidade de colonização e maior tolerância a perturbações ou distúrbios ambientais. São considerados "persistentes" ou "estrategistas-k" nematóides que apresentam baixa taxa reprodutiva, ciclo de vida longo, baixa capacidade de colonização e maior sensibilidade a distúrbios do ambiente. Essas características ecológicas foram utilizadas para a criação de uma escala de valores de 1 a 5 , chamados de "valores c-p", sendo que valores mais próximos de 1 estão relacionados a nematóides colonizadores e valores mais próximos de 5 estão relacionados a nematóides persistentes. Os valores c-p são utilizados para o cálculo do índice de maturidade, que é uma média ponderada desses valores, com base nas abundâncias relativas desses nematóides. $O$ índice de maturidade é calculado levando em consideração somente os nematóides de vida livre (não fitoparasitos). $\mathrm{O}$ índice de parasitos de plantas considera somente os nematóides fitoparasitos e é calculado da mesma forma (Bongers, 1990). Yeates (1994) propôs que 
o índice de maturidade fosse calculado considerando os nematóides de todos os grupos tróficos.

Métodos de análise estatística multivariada podem ser usados em estudos de diversidade de nematóides, quando se objetiva a comparação de um grande número de áreas ou comunidades. Um dos métodos mais utilizados é a análise de agrupamento. Essa análise é utilizada para se colocar áreas similares em grupos ou "ramos" que são organizados em uma estrutura hierárquica tipo "árvore", chamada dendrograma. Os grupos ou "ramos" delimitam ou representam diferentes comunidades bióticas. (Jongman et al., 1995; Ludwig \& Reynolds, 1988).

\subsection{Estudos de diversidade de nematóides}

Até o final da década de setenta, estudos sobre diversidade de nematóides que consideravam todos os grupos tróficos e taxonômicos que ocorrem em solos eram escassos. Até então, a maioria dos trabalhos relacionados ao assunto limitava-se à apresentação de listas de ocorrência de espécies (ou outras categorias taxonômicas) e observações gerais, a partir de levantamentos realizados no campo (Norton, 1978). Após o início da década de oitenta, houve um aumento do número de trabalhos sobre o assunto, inclusive sendo realizados estudos mais aprofundados, em que se utilizaram, para caracterizar comunidades, métodos já conhecidos em pesquisa ecológica, como a utilização de índices matemáticos e/ou análises de estatística multivariada. Contudo, esse avanço que ocorreu internacionalmente nos estudos de diversidade de nematóides não foi acompanhado pela pesquisa realizada no Brasil, onde trabalhos com esse enfoque ainda são raros.

Um estudo de diversidade de nematóides pode ser classificado de acordo com os tipos de ecossistemas amostrados: apenas ecossistemas naturais; apenas agroecossistemas; ecossistemas naturais e agroecossistemas. 


\subsubsection{Estudos em ecossistemas naturais}

Estudos de diversidade de nematóides com amostragem apenas em ecossistemas naturais já foram realizados na Alemanha (Ruess, 1995), Austrália (Reay \& Wallace, 1981), Brasil (Huang et al., 1996), Canadá (Kimpinski \& Welch, 1971; Panesar et al., 2001), Eslováquia (Valocká \& Sabová, 1998), Estados Unidos (Al Banna \& Gardner, 1996; Freckman et al., 1975; McSorley, 1993; Mishra \& Mitchell, 1987; Johnson et al., 1972; 1973; 1974; Norton \& Koffmann, 1974; Seastedt et al., 1988; Schmitt \& Norton, 1972), França (Armendáriz \& Arpin, 1996), Holanda (De Goede, 1996); Inglaterra (Hodda \& Wanless, 1994; Yuen, 1966), Israel (Liang et al., 2002), Itália (Vinciguerra \& Giannetto, 1987), Nova Zelândia (Yeates \& Williams, 2001), Quênia (Coleman et al., 1991), Romênia (Popovici \& Ciobanu, 2000), Rússia (Romanenko et al., 1997) e Suécia (Hyvönen \& Persson, 1990; Sohlenius \& Wasilewska, 1984).

Considerando que muitos nematóides de áreas cultivadas provavelmente tiveram seus ancestrais em áreas nativas, estudos de comunidades de nematóides em áreas de vegetação nativa podem contribuir para uma melhor compreensão sobre a presença e ecologia de nematóides fitoparasitos em áreas cultivadas, como também sobre a provável importância dos mesmos em relação à vegetação nativa (Schmitt \& Norton, 1972).

Huang et al. (1996) estudaram os grupos taxonômicos e tróficos dos nematóides associados à sucupira branca (Pterodon pubescens Benth.) em cerrado nativo no Brasil (Brasília, DF) e encontraram importantes gêneros de nematóides fitoparasitos na rizosfera dessa planta, como: Trophotylenchulus, Meloidogyne, Helicotylenchus, Hemicriconemoides, Discocriconemella, Hoplolaimus, Criconemella, Pratylenchus, Paratrichodorus, Rotylenchulus, Peltamigratus, Xiphinema e Paratylenchus (em ordem decrescente de abundâncias relativas obtidas). Por outro lado, os autores afirmaram que as altas abundâncias relativas de nematóides onívoros confirmaram que o solo amostrado estava sob baixa intervenção humana. 


\subsubsection{Estudos em agroecossistemas}

A maior parte dos estudos de diversidade de nematóides foi realizada com amostragem apenas em agroecossistemas. Em alguns desses estudos somente foram considerados os nematóides fitoparasitos (Coyne et al., 2001; Ferris et al., 1971; Kandji et al., 2001; Mukherjee \& Dasgupta, 1982; Mukherjee \& Dasgupta, 1983; Niblack \& Bernard, 1985; Verschoor et al., 2001). Os estudos em que foram considerados nematóides de diversos hábitos alimentares estão apresentados na Tabela 1.

Tabela 1. Estudos de diversidade de nematóides com amostragem apenas em agroecossistemas.

\begin{tabular}{lll}
\hline Localidade (país) & Cultura(s) & Referência bibliográfica \\
\hline Alemanha & diversas culturas & Lenz \& Eisenbeis (2000) \\
Austrália & tremoço e trigo & Van Vliet et al. (2000) \\
Brasil & soja & Gomes (1996) \\
Croácia & diversas culturas & Ivezic et al. (2000) \\
Eslováquia & diversas culturas & Renco (2002) \\
Estados Unidos & adubos verdes & MacGuidwin \& Layne (1995) \\
& Citrus & Porazinska et al. (1998a) \\
& & Porazinska et al. (1998b) \\
& & Porazinska et al. (1999) \\
& Citrus e pastagem & McSorley (1997) \\
& Cucurbita spp. & Porazinska \& Coleman (1993) \\
& diversas culturas & Neher (1999) \\
& & Neher \& Olson (1999) \\
& & Neher et al. (1995) \\
& & Neher et al. (1998) \\
& & Parmelee \& Alston (1986) \\
& pastagem & Wall-Freckman \& Huang (1998) \\
& tomate & Bulluck III et al. (2002) \\
& Nombela et al. (1999) \\
&
\end{tabular}


Tabela 1. Estudos de diversidade de nematóides com amostragem apenas em agroecossistemas.

\begin{tabular}{|c|c|c|}
\hline Localidade (país) & Cultura(s) & Referência bibliográfica \\
\hline & Pinus & Armendáriz \& Hernández (1995) \\
\hline \multirow[t]{2}{*}{ Honduras } & culturas consorciadas & Powers et al. (1993) \\
\hline & pastagens & Powers \& McSorley (1994) \\
\hline \multirow[t]{2}{*}{ Índia } & arroz e pastagem & Mishra \& Dash (1981) \\
\hline & diversas culturas & Samathanam \& Chawla (1982) \\
\hline Israel & batata & Liang et al. (1999) \\
\hline Itália & Pinus & Vinciguerra et al. (1995) \\
\hline \multirow[t]{9}{*}{ Nova Zelândia } & aspargo e milho & Wardle et al. (1995) \\
\hline & & Yeates et al. (1993) \\
\hline & & Yeates et al. (1999) \\
\hline & aveia e milho & Yeates \& Hughes (1990) \\
\hline & pastagens & Yeates et al. (1977) \\
\hline & & Yeates et al. (1978a) \\
\hline & & Yeates et al. (1978b) \\
\hline & & Yeates (1981) \\
\hline & $\begin{array}{l}\text { sistemas agroflorestais de } \\
\text { Pinus e pastagens }\end{array}$ & Yeates et al. (2000) \\
\hline Reino Unido & pastagens & Yeates et al. (1997) \\
\hline Senegal & amendoim e milheto & Villenave et al. (2001) \\
\hline \multirow[t]{2}{*}{ Suécia } & pastagem & Sohlenius \& Sandor (1989) \\
\hline & sistemas de rotação & Sohlenius \& Sandor (1987) \\
\hline
\end{tabular}

Gomes (1996) observou em culturas de soja (Glycine max Merr.) no Distrito Federal, Brasil, que os nematóides micófagos tiveram maiores abundâncias no final do ciclo da cultura, período em que as raízes encontram-se em alta decomposição por ação de microrganismos, especialmente fungos. Houve, por outro lado, segundo o autor, uma redução nas abundâncias dos nematóides micófagos após o final do ciclo da cultura, 
certamente pela ausência de substrato para decomposição fúngica. Além disso, o autor observou também um aumento nas abundâncias de nematóides bacteriófagos após o início do período chuvoso, com subseqüente queda no período seco.

Vários estudos de diversidade de nematóides em agroecossistemas têm sido realizados com o objetivo de verificar o efeito de determinado manejo agrícola nas comunidades de nematóides do solo, como: adubação química (Porazinska \& Coleman, 1995); adubação orgância e química (Bulluck III et al., 2002); adubação verde (MacGuidwin \& Layne, 1995); aração (Sohlenius \& Sandor, 1989); controle de plantas daninhas (Yeates et al., 1993); cultivo orgânico e convencional (Neher, 1999; Yeates et al., 1997); cultivos consorciados (Powers et al., 1993); irrigação (Porazinska et al., 1998; pousio (Villenave et al., 2001); semeadura direta ("plantio" direto) e cultivo convencional (Lenz \& Eisenbeis, 2000; Parmelee \& Alston, 1986; Yeates \& Hughes, 1990); sistema agroflorestal (Yeates et al., 2000); sistemas de rotação de culturas (Neher \& Olson, 1999; Sohlenius et al., 1987; Yeates \& Hughes, 1990). Em alguns estudos, as comunidades de nematóides foram utilizadas como bio-indicadores da condição ecológica do solo (Nombela et al., 1999; Porazinska et al., 1999; Wardle et al., 1995; Yeates et al., 1999). Porazinska et al. (1998) avaliaram a relação entre as comunidades de nematóides do solo e a sustentabilidade da produção agrícola.

\subsubsection{Estudos em ecossistemas naturais e agroecossistemas}

Relativamente poucos estudos foram realizados com amostragem em ecossistemas naturais e agroecossistemas, os quais serão comentados a seguir, em ordem cronológica de publicação.

Zamith \& Lordello (1957) realizaram algumas observações sobre nematóides presentes em solos de matas e em solos cultivados no Estado de São Paulo, Brasil, e concluíram que: os solos não perturbados encerravam uma fauna de nematóides com número superior de gêneros e espécies; quando se inicia o cultivo em uma área ocorre a eliminação de alguns nematóides com permanência de outros e, comumente, introdução de alguns por meio de material vegetal infestado, bem como máquinas e ferramentas que trazem solo aderente. 
Caveness (1972) estudou as alterações de populações de nematóides fitoparasitos após derrubada da vegetação nativa florestal e estabelecimento de culturas agrícolas na Nigéria e verificou que as densidades populacionais dos nematóides diminuíram $85 \%$ após a retirada da vegetação nativa; contudo, essas densidades cresceram após o início de cada cultivo e tornaram a diminuir em períodos de pousio. $\mathrm{O}$ autor concluiu que as práticas agrícolas favoreceram algumas espécies de nematóides, como Pratylenchus coffeae (Zimmermann, 1898) Filipjev \& Schuurmans Stekhoven, 1941, Meloidogyne incognita (Kofoid \& White, 1919) Chitwood, 1949 e Helicotylenchus pseudorobustus (Steiner, 1914) Golden, 1956, em detrimento de outras, dos gêneros Helicotylenchus, Scutellonema, Xiphinema, Paratylenchus e Criconemoides. Lal et al. (1983), em estudo semelhante, verificaram que a queima da cobertura vegetal nativa como prática para abertura de áreas para agricultura, bem como a aração, causaram reduções nas populações de nematóides fitoparasitos. A implantação de várias culturas favoreceu a multiplicação de nematóides fitoparasitos; contudo, o cultivo de Crotalaria juncea L. e o pousio tiveram o efeito contrário. Além disso, o cultivo de Crotalaria juncea favoreceu nematóides de vida livre, como Dorylaimus, Discolaimus, Mononchus e Rhabditis.

Cares \& Huang (1991) realizaram estudo de diversidade de nematóides fitoparasitos, identificados até nível de gênero, a partir de amostragens realizadas em mata ciliar, cerrado e diversas culturas (perenes e anuais) no Distrito Federal, Goiás e Minas Gerais (Brasil). Os maiores números de gêneros de fitonematóides ocorreram, em ordem decrescente, nos seguintes ecossistemas: cerrado, mata ciliar, culturas perenes e culturas anuais. Em geral, nematóides da superfamília Criconematoidea e das famílias Tylenchidae e Anguinidae, que tiveram alta incidência em vegetação nativa, tornaram-se não detectáveis ou suas abundâncias foram muito reduzidas devido ao cultivo. Excepcionalmente, o gênero Trophotylenchulus (superfamília Criconematoidea) apresentou maiores abundâncias em culturas de Eucalyptus e Pinus, em relação à vegetação nativa de cerrado. $\mathrm{O}$ gênero Meloidogyne sobreviveu melhor em cultura de Pinus e os gêneros Aphelenchoides, Helicotylenchus e Tylenchus em cultura de soja, em relação ao cerrado. Os gêneros Pratylenchus, Pseudhalenchus e Ditylenchus foram 
detectados somente em áreas cultivadas. $\mathrm{O}$ índice de similaridade de Jaccard foi maior $(0,70)$ para a comparação entre cerrado e eucalipto, sendo realizadas em geral comparações entre cerrado e áreas cultivadas.

Freckman \& Ettema (1993) estudaram comunidades de nematóides em ecossitemas naturais (duas áreas) e agroecossistemas (quatro seqüências de rotação de culturas anuais e duas culturas perenes) sob diferentes níveis de intervenção humana, nos Estados Unidos. As culturas anuais utilizadas foram milho, soja e trigo (Triticum aestivum L.); as culturas perenes foram alfafa (Medicago sativa L.) e Populus euramericana Guinier ("poplar"). As áreas agrícolas apresentavam níveis variados de interferência em suas condições naturais (ou perturbação, como chamam alguns autores), desde áreas sem utilização de produtos químicos industrializados e baixo impacto da ação humana até áreas com utilização de produtos químicos industrializados e mais impactadas pelo manejo humano. Maiores riqueza de toxa e diversidade foram encontradas em vegetação nativa. A área cultivada sem uso de produtos químicos industrializados também apresentou elevado número de toxa, porém baixa eqüitabilidade ou uniformidade entre as abundâncias, o que resultou em um baixo índice de diversidade de Shannon-Weaver. Nematóides bacteriófagos foram os mais abundantes em todas as áreas, enquanto que os micófagos foram mais abundantes em vegetação nativa e os fitoparasitos apresentaram a menor abundância em cultivo orgânico. Nematóides onívoros e predadores representaram uma pequena proporção da comunidade em todas as áreas.

Hánel (1995) realizou estudo de comunidades de nematóides em quatro áreas na República Tcheca, com as seguintes características: seqüência de culturas trigo/batata; pousio após cultura de milho; campo; floresta. O maior índice de diversidade de Shannon-Weaver foi obtido para a área de campo e o menor para a área cultivada. Altos valores de índices de maturidade foram obtidos para a área de campo, indicando uma comunidade de nematóides mais estável ou madura. Os índices de diversidade e maturidade apresentaram pequenas diferenças para a área de floresta em relação à área de campo. 
Huang \& Cares (1995) realizaram estudo de diversidade de nematóides fitoparasitos, identificados até nível de gênero, em vegetação nativa (cerradão, cerrado e mata ciliar) e cultivada (culturas anuais e perenes) no Brasil Central. Os autores afirmaram que: a diversidade de plantas costuma ser maior em cerrado ou cerradão do que em mata ciliar ou em áreas cultivadas; menor diversidade de plantas em geral ocorre em áreas cultivadas; a diversidade de nematóides apresentou paralelismo em relação à diversidade de plantas dos ambientes estudados. A abundância de nematóides foi maior em áreas de culturas perenes, provavelmente devido a grande biomassa radicular, e a menor em áreas de culturas anuais.

Bloemers et al. (1997) verificaram o efeito de perturbações (inclusive devido à implantação de agricultura) em uma floresta na República de Camarões, África, observando que houve aparentemente pouco efeito na riqueza de taxa de nematóides, exceto nas áreas mais perturbadas. $O$ índice de maturidade não diminuiu com crescentes perturbações, o que os autores julgaram fato surpreendente e comentaram que há necessidade de trabalhos de pesquisa para que esse índice possa ser melhor interpretado com relação a nematóides de solos tropicais, uma vez foi desenvolvido considerando as condições temperadas. As perturbações afetaram não somente a riqueza, mas também a composição das comunidades de nematóides, com impactos semelhantes em todos os grupos tróficos.

Yeates \& King (1997) estudaram as comunidades de nematóides em pastagens nativas e cultivadas na Austrália e concluiram que a substituição da pastagem nativa por espécies exóticas e a adubação regular para manutenção dessas espécies resultaram em marcadas alterações na fauna nematológica (composição taxonômica e abundâncias). Houve um aumento na abundância total de nematóides devido ao cultivo e grande parte desse aumento foi devido a nematóides bacteriófagos, o que indicou, segundo os autores, melhor qualidade dos resíduos vegetais como fonte de alimento para a microbiota, especialmente bactérias. A abundância de nematóides predadores e o índice de maturidade foram menores em pastagens cultivadas.

Coyne et al. (1999) realizaram observações sobre a dinâmica de populações de nematóides fitoparasitos em floresta e em culturas de arroz estabelecidas após derrubada 
de vegetação nativa florestal na Costa do Marfim, África. A abertura de clareira na floresta, por si só, teve pouco efeito imediato na diversidade de nematóides. Com a introdução de cultura de arroz, contudo, ocorreram rápidas alterações nas comunidades de nematóides, causando diminuição na diversidade e dominância de poucas espécies.

Mattos (1999) caracterizou as comunidades de nematóides em quatro tipos de vegetação nativa e quatro tipos de culturas agrícolas no Brasil Central: cerrado, cerradão, mata, campo, café, eucalipto, milho e tomate. As maiores abundâncias de nematóides ocorreram nas culturas anuais, enquanto que as menores ocorreram em eucalipto. A riqueza de gêneros foi maior em cerrado e menor em tomate. Em vegetação nativa, observou-se prevalência das famílias Tylenchulidae, Tylenchidae, Criconematidae, Hoplolaimidae e Cephalobidae. Em áreas cultivadas, as famílias prevalentes foram Cephalobidae, Hoplolaimidae, Panagrolaimidae, Rhabditidae e Heteroderidae. Foi obtida a seguinte ordem decrescente para as diversidades de nematóides (avaliadas por meio da riqueza e índices de diversidade): cerrado, mata, campo, eucalipto, café, milho, tomate. Para o índice de maturidade, foi obtida a seguinte ordem decrescente: campo, cerradão, cerrado, mata, eucalipto, café, milho, tomate. $\mathrm{Na}$ maioria das áreas cultivadas, os nematóides bacteriófagos foram dominantes, enquanto que predadores e onívoros foram minoritários em todos os tipos de ecossistemas. Em vegetação nativa e cultura de milho, a prevalência foi dos fitoparasitos. Os onívoros apresentaram as maiores abundâncias relativas em vegetação nativa, eucalipto e café. Destacou-se a maior abundância relativa da superfamília Criconematoidea em vegetação nativa. Os gêneros chave selecionados que melhor possibilitaram a distinção entre áreas foram: Trophotylenchulus e Discocriconemella. $\mathrm{O}$ gênero Trophotylenchulus apresentou elevadas abundâncias em todas as áreas de vegetação nativa, distinguindo-as das demais. Discocriconemella apresentou elevadas abundâncias em cerrado e cerradão, distinguindo essas áreas das demais.

Valocká et al. (2001) estudaram as comunidades de nematóides em quatro localidades na Eslováquia. Em cada localidade foram selecionados dois tipos de ecossistemas: pastagem nativa e cultura de cereal. Os números de gêneros (riqueza) e abundâncias foram maiores em culturas de cereais. Os nematóides fitoparasitos 
constituíram grupo trófico dominante em todas as localidades e ecossistemas. Em seguida, os mais abundantes foram os bacteriófagos, na maioria das localidades. Os índices de maturidade, cujos valores maiores indicam menor impacto ambiental, foram maiores em pastagens nativas do que em culturas de cereais.

Segundo a literatura consultada, doze estudos já foram realizados com amostragem em ecossistemas naturais e agroecossistemas, sendo que sete consideraram todos os hábitos alimentares de nematóides (Bloemers et al., 1997; Freckman \& Ettema, 1993; Hánel, 1995; Mattos, 1999; Valocká et al., 2001; Zamith e Lordello, 1957; Yeates \& King, 1997) e cinco consideraram apenas os fitoparasitos (Cares \& Huang, 1991; Caveness, 1972; Coyne et al., 1999; Huang \& Cares, 1995; Lal et al., 1983). Quatro desses estudos foram realizados no Brasil, sendo que dois consideraram todos os hábitos alimentares (Mattos, 1999; Zamith \& Lordello, 1957) e outros dois apenas os fitoparasitos (Cares \& Huang, 1991; Huang \& Cares, 1995). Nos trabalhos em que foram considerados todos os grupos tróficos de nematóides, houve maior diversidade em áreas de vegetação nativa em relação às áreas cultivadas, exceto no de Valocká et al. (2001), provavelmente devido a dominância acentuada de nematóides fitoparasitos em todas as áreas amostradas nesse estudo. Em relação ao índice de maturidade, em todos os estudos ocorreram maiores valores em áreas de vegetação nativa em relação às áreas cultivadas, exceto no de Bloemers et al. (1997), que não observaram diferenças entre os índices desses dois tipos de ecossistemas.

Yeates (1991), em revisão sobre o assunto, destacou três principais aspectos do impacto sobre a fauna do solo decorrentes de mudanças históricas do uso da terra, com a retirada da vegetação original e a implantação de cultivos agrícolas: diminuição na abundância ou eliminação de espécies nativas; exploração dos habitats modificados por espécies nativas; disseminação (geral ou restrita) de espécies introduzidas. Como exemplos, o autor cita os nematóides da família Criconematidae em relação ao primeiro aspecto, nematóides fitoparasitos nativos em relação ao segundo e nematóides fitoparasitos exóticos em relação ao terceiro. Com a interferência humana em ecossistemas, por meio da agricultura, muitas espécies são introduzidas em novas áreas, podendo substituir as populações nativas. As espécies introduzidas são caracterizadas 
em geral como pragas ou patógenos, sendo favorecidas pelas novas condições ecológicas que são estabelecidas pelo cultivo contínuo da área. Quando uma nova espécie é introduzida em uma área, padrões de atividade bio-ecológica, anteriormente estabelecidos na comunidade, podem ser modificados e uma nova interação entre as espécies pode se desenvolver. A quantidade de modificações nesses padrões de atividade relaciona-se diretamente com a habilidade competitiva da espécie introduzida (Jusino-Atresino \& Phillips Jr., 1994). Agroecossistemas são geralmente estabelecidos como monoculturas e práticas de manejo associadas resultam em modificações na estrutura do solo, que, por sua vez, causam maiores flutuações de umidade e temperatura, em relação a áreas não cultivadas. Os instáveis habitats resultantes inibem o estabelecimento e a permanência de muitos nematóides. A agricultura favorece alguns nematóides que são capazes de sobreviver e reproduzir em um ambiente de freqüentes mudanças, inclusive em relação a fontes de alimento. Portanto, comunidades de nematóides em agroecossistemas geralmente apresentam riqueza e diversidade mais baixas que em áreas naturais (Norton \& Niblack, 1991). 


\section{MATERIAL E MÉTODOS}

\subsection{Local de estudo}

As amostras nematológicas foram coletadas em áreas situadas no município de São Carlos (2201'10" S, 4753'38" O; altitude média: 830 m), Estado de São Paulo. O clima local, segundo a sistemática de Köppen, é classificado como uma transição entre Aw (tropical, com verão úmido e inverno seco) e Cwa (tropical com inverno seco, verão quente e úmido), sendo caracterizado por uma temperatura média mensal de $21^{\circ} \mathrm{C}$ e precipitação pluviométrica anual média de $1520 \mathrm{~mm}$. Apesar do clima tropical, em alguns anos frentes frias no inverno são responsáveis por quedas bruscas de temperatura e ocorrência de geadas. Normalmente ocorre uma sucessão de período chuvoso, que se estende de outubro a março, e outro seco, de abril a setembro (Oliveira \& Prado, 1984). Segundo estudo de Lorandi (1985), em São Carlos predominam solos do tipo latossolo, ocorrendo também areias quartzosas, litossolos e solos hidromórficos; quimicamente, os solos em geral são ácidos, com teores elevados de alumínio trocável, pobres em matéria orgânica e deficientes na maioria dos elementos essenciais às plantas.

Para execução do trabalho de tese, foram coletadas amostras em três áreas no local: área de vegetação nativa, área de cultura perene e área de cultura anual (Figuras 1, $2,3$ e 4$)$.

A vegetação nativa em São Carlos é predominantemente do tipo cerrado, um dos mais importantes ecossistemas naturais do Brasil. A vegetação de cerrado em São Carlos é caracterizada como formação não florestal herbáceo-lenhosa, herbáceo-arbustiva, com árvores perenifólias, constituindo um tipo muito peculiar em que os elementos se distribuem em nítidos estratos rasteiro, arbustivo e arbóreo, este último apresentando, em média, 3 a 5 metros de altura (Lorandi, 1985). A área de 
vegetação nativa (cerrado "strictu sensu", conforme Coutinho, 1978) utilizada no estudo apresenta solo do tipo latossolo vermelho-amarelo. Tanto a área de cultura perene como de cultura anual estão sobre latossolo vermelho-amarelo anteriormente coberto com vegetação de cerrado "strictu sensu". Cada uma das três áreas de coleta foi delimitada em 1ha, sendo obtidas as seguintes coordenadas através de equipamento GPS ("Global Positioning System"): cerrado: $21^{\circ} 57^{\prime} 54^{\prime \prime} \mathrm{S}$ 47 $53^{\prime} 3^{\prime \prime} \mathrm{W}$; goiabal: $22^{\circ} 05^{\prime} 11^{\prime \prime} \mathrm{S}$ $47^{\circ} 48^{\prime} 25^{\prime \prime} \mathrm{W}$; milharal: $21^{\circ} 57^{\prime} 12^{\prime} \mathrm{S} 47^{\circ} 50^{\prime} 42^{\prime \prime} \mathrm{W}$.

A área de vegetação nativa utilizada no estudo é da reserva de preservação da Universidade Federal de São Carlos. Essa reserva é de aproximadamente 20ha e a vegetação apresenta os estratos herbáceo, arbustivo e arbóreo. $\mathrm{O}$ estrato arbóreo possui espécies que chegam até $10 \mathrm{~m}$ de altura, como, por exemplo, Anadenanthera falcata (Benth.) Speg.. No entanto, árvores entre 2 a $6 \mathrm{~m}$ são bem mais comuns, como: Aspidosperma tomentosum Mart., Bowdichia virgilioides H.B.K., Caryocar brasiliense Camb., Eriotheca gracilipes (K. Schum.) A. Robins, Kielmeyera coriacea Mart., Kielmeyera variabilis Mart., Qualea dichotoma Warm. e Styrax camporum Pohl.. O estrato arbóreo é pouco denso, de forma que as copas das árvores raramente se encontram e a luz atinge sem atenuação praticamente todo o estrato arbustivo e herbáceo. As espécies Bauhinia holophylla Steud., Cassia chrysocarpa Desv., Davilla rugosa Poir e Duguetia furfuracea (St. Hill) Bent \& Hook são as mais comuns no estrato arbustivo. O estrato herbáceo é bem reprentatado na vegetação, sendo ocupado principalmente por gramíneas, entre as quais se destaca o capim gordura (Mellinis minutiflora Beauv.). No estrato herbáceo, o capim gordura pode chegar à mesma altura ( $1 \mathrm{~m}$, na época chuvosa) de alguns exemplares de espécies do estrato arbustivo, como por exemplo, Davilla rugosa e Duguetia furfuracea (Kanno, 1993; Prado, 1994; Silva, 1998; Tambelini, 1999).

A cultura perene selecionada para estudo foi de uma planta nativa da América do Sul; a goiabeira, Psidium guajava L. (Myrtaceae). A área de cultura perene do estudo é a do goiabal da Fazenda Itaguassu, São Carlos. O goiabal ocupa aproximadamente 90ha, de plantio comercial da cultivar Paluma no espaçamento $7 \mathrm{~m} \mathrm{x}$ 5m. A idade do pomar na época da primeira amostragem (maio de 1999) era de 
aproximadamente 10 anos. Antes da implantação do pomar de goiabeira, a área era ocupada por pastagens (de Brachiaria decumbens Stapf. ou Pennisetum purpureum Schum.). Nessa área de goiabal eram normalmente realizados os tratos culturais adequados; contudo, durante os três anos que antecederam as amostragens nematológicas e também durante todo o período em que as mesmas foram realizadas, o pomar foi conduzido com redução nas medidas de controle de plantas daninhas (uso de roçadeira nas entrelinhas) e de pragas (pulverizações de inseticidas), bem como na adubação e calagem, caracterizando um sistema de baixa eficiência agronômica. A alta infestação de plantas daninhas na área foi caracterizada por Gonçalves (1999), em levantamento realizado em 1997. As principais plantas daninhas encontradas na projeção das copas de goiabeiras, em ordem decrescente de densidade (número de plantas/ha), foram as seguintes: Spermacoce latifolia Aubl., Alternanthera tenella Colla, Brachiaria decumbens Stapf., Bidens pilosa L., Chamaesyce hirta (L.) Millesp., Commelina benghalensis L., Ageratum conyzoides L., Phyllanthus tenellus Roxb., Conyza bonariensis (L.) Cronq., Emilia sonchifolia (L.) DC., Portulaca oleracea L., Ipomoea purpurea (L.) Roth. e Solanum americamum Mill..

A cultura anual selecionada foi o milho (Zea mays L.), de área da EMBRAPA Pecuária Sudeste, São Carlos. Essa área ocupa aproximadamente 40ha, com cultivo de milho para silagem (híbrido BR-201), com espaçamento entre linhas de $1 \mathrm{~m}$ e 5 plantas por metro. Irrigação com pivô central foi realizada na área, do tipo complementar, ou seja, com o objetivo de suprir a quantidade suficiente de água para o crescimento das plantas nos períodos secos. $\mathrm{O}$ controle fitossanitário (principalmente em relação a formigas), controle de plantas daninhas (com aplicação de herbicida em pré-emergência) e adubação são práticas normalmente realizadas. A área tem sido cultivada com milho há aproximadamente 10 anos, sendo que anteriormente havia no local pastagem de Brachiaria decumbens. A partir do sétimo ano de cultivo exclusivo de miho na área, foi iniciado o uso de rotação de culturas com aveia (Avena sativa L.) no inverno, soja (Glycine max Merr.) ou adubos verdes (crotalárias, principalmente Crotalaria juncea L.) na entressafra, permanecendo o milho como cultura principal em todos os anos. 


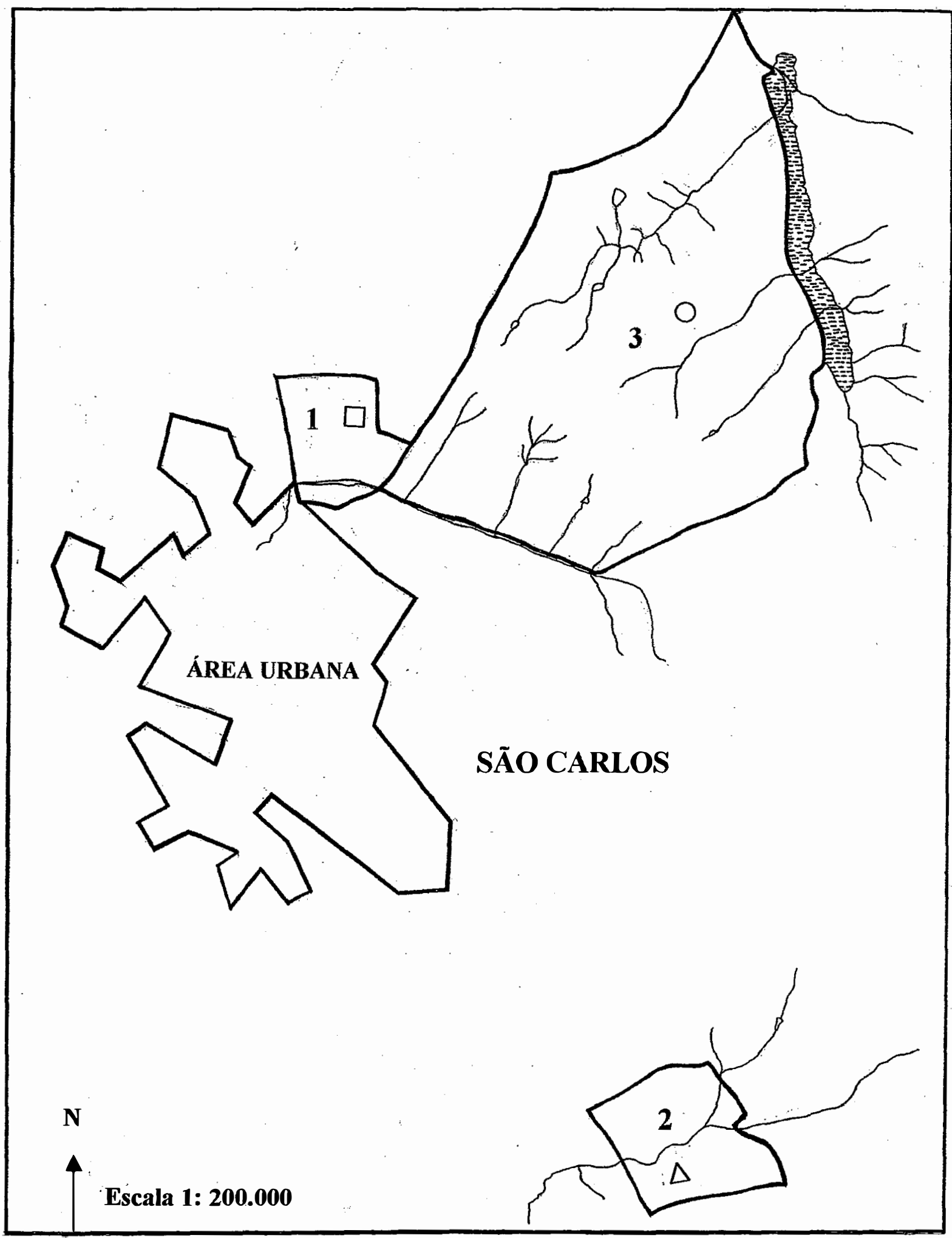

Figura 1 - Localização das áreas de amostragens para estudo de diversidade de nematóides em São Carlos, SP. 1- Universidade Federal de São Carlos ( $\square$ cerrado); 2- Fazenda Itaguassu ( $\Delta$ goiabal); 3- EMBRAPA-Pecuária Sudeste ( O milharal). Fonte: Prefeitura Municipal de São Carlos. 


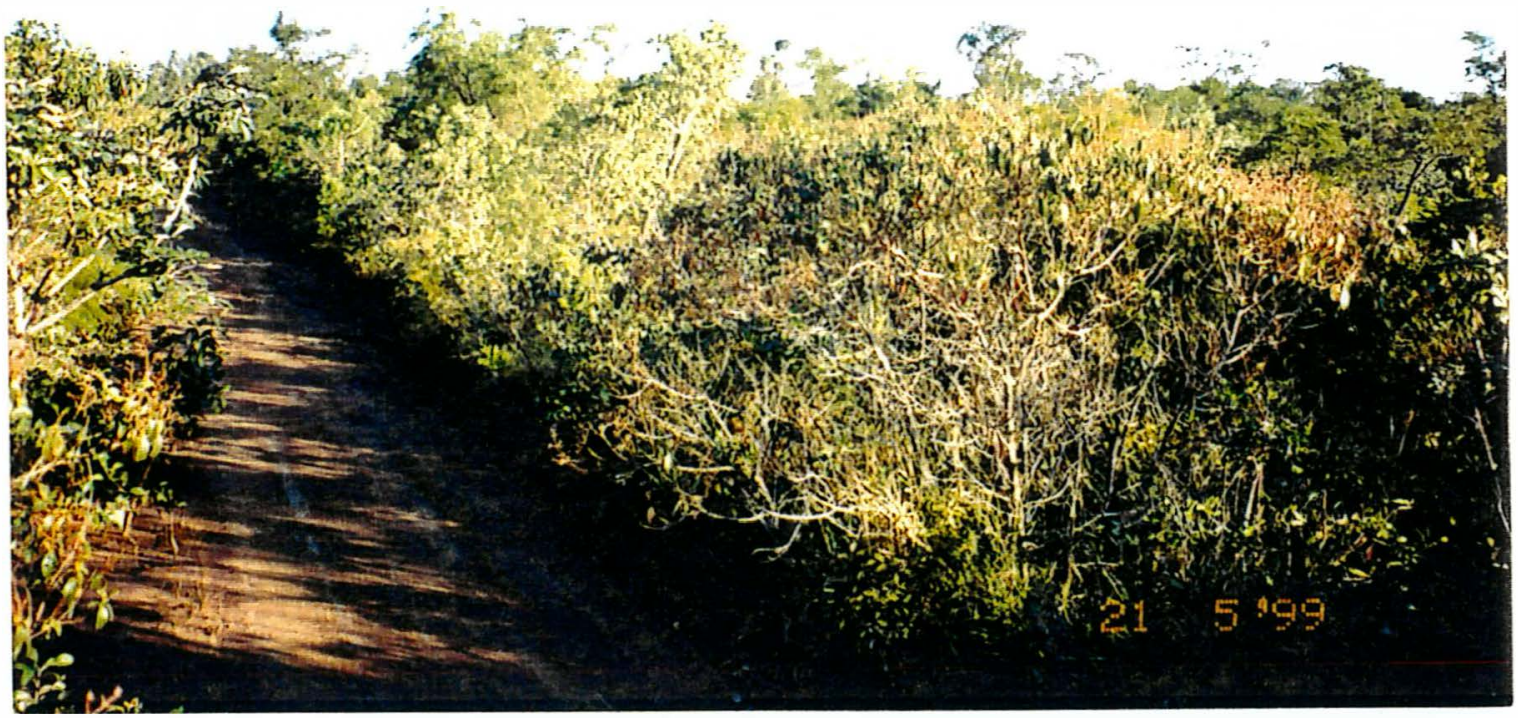

Figura 2 - Área de vegetação nativa (cerrado "strictu sensu") em São Carlos (SP), da reserva de preservação da Universidade Federal de São Carlos, utilizada para estudo de diversidade de nematóides.

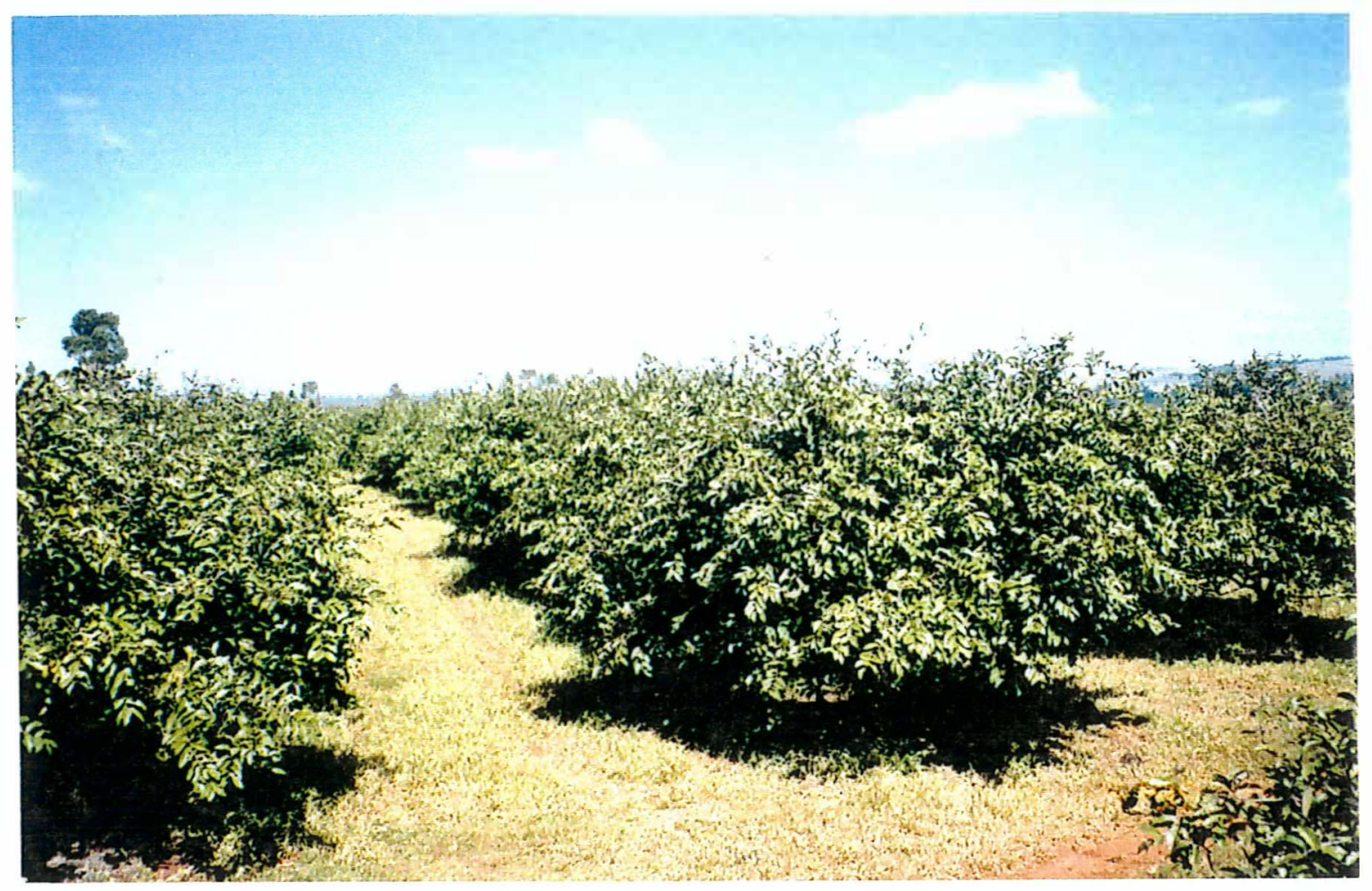

Figura 3 - Área de goiabal da Fazenda Itaguassu, em São Carlos (SP), utilizada para estudo de diversidade de nematóides. 


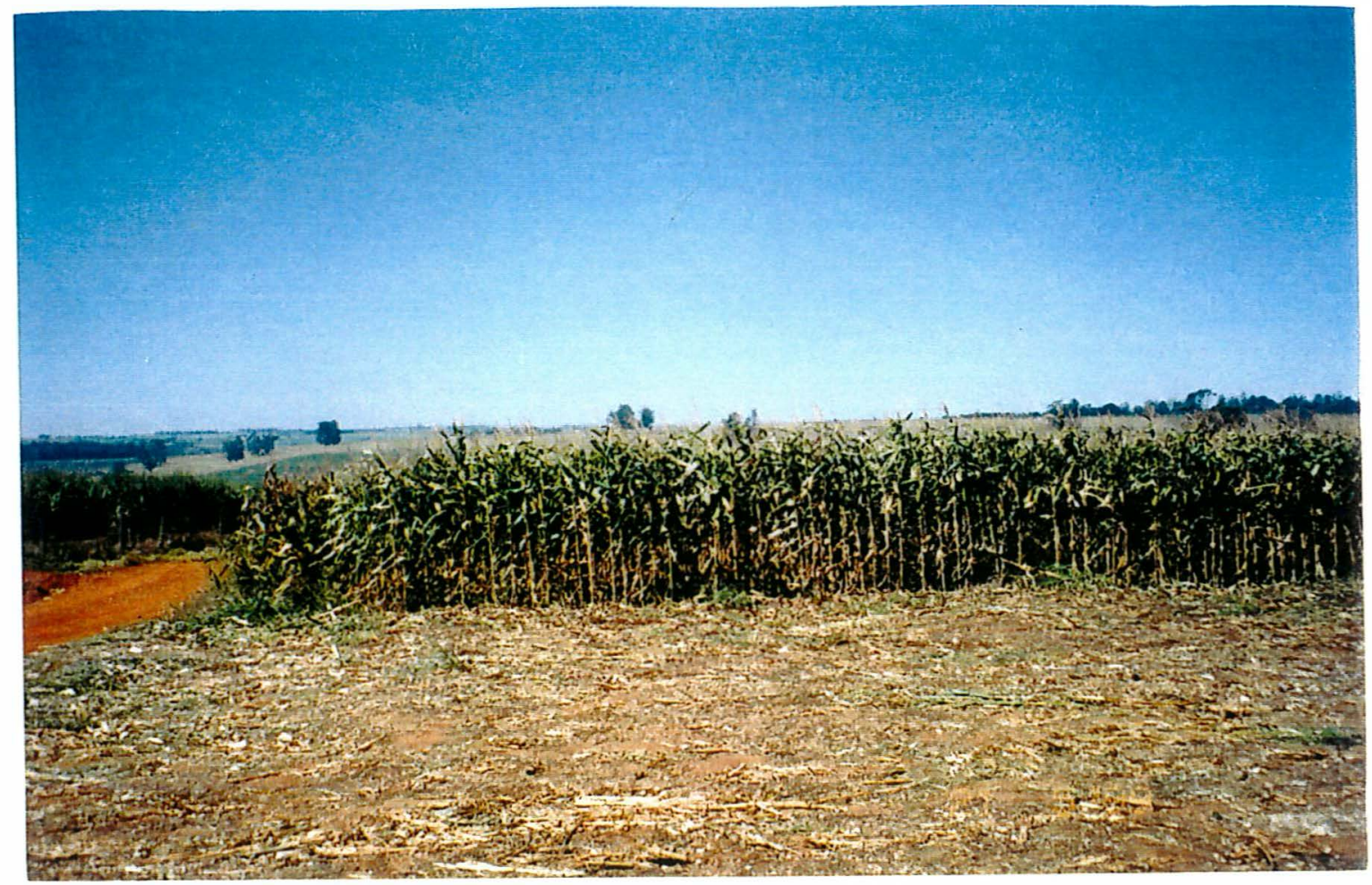

Figura 4 - Área de milharal da EMBRAPA - Pecuária Sudeste, em São Carlos (SP), utilizada para estudo de diversidade de nematóides.

Para complementar a caracterização das três áreas de amostragem no local, foram realizadas análises fisicas (granulométricas) e químicas de solo, com utilização de uma amostra composta de dez sub-amostras para cada área (cerrado, goiabal e milharal), considerando as mesmas áreas de amostragem, com tamanho de 1ha cada uma. Essas amostras foram coletadas no período de 13 a 15 de fevereiro de 2000 (Tabelas 2, 3 e 4). 
Tabela 2. Análises granulométricas de solo das três áreas de amostragem em São Carlos (SP). ${ }^{1}$

\begin{tabular}{lcccc}
\hline & areia (\%) & silte (\%) & argila (\%) & classe de textura \\
\hline Cerrado & 60 & 4 & 36 & argilosa \\
Goiabal & 72 & 4 & 24 & média-arenosa \\
Milharal & 64 & 4 & 32 & média-argilosa \\
\hline
\end{tabular}

1- Realizadas no laboratório de análise de solo do Departamento de Solos e Nutrição de Plantas da ESALQ/USP, Piracicaba, SP.

Tabela 3. Análises químicas de solo das três áreas de amostragem em São Carlos (SP). ${ }^{1}$

\begin{tabular}{lcccccccccc}
\hline & $\begin{array}{c}\mathrm{pH} \\
\mathrm{CaCl}_{2}\end{array}$ & $\begin{array}{c}\mathrm{M} . \mathrm{O} \\
\mathrm{g} / \mathrm{dm}^{3}\end{array}$ & $\begin{array}{c}\mathrm{P} \\
\mathrm{mg} / \mathrm{dm}^{3}\end{array}$ & $\mathrm{~K}$ & $\mathrm{Ca}$ & $\begin{array}{c}\mathrm{Mg} \\
\mathrm{mmolc} / \mathrm{dm}^{3}\end{array}$ & $\begin{array}{c}\mathrm{H}+\mathrm{Al} \\
\text { SB }\end{array}$ & $\mathrm{T}$ & $\begin{array}{c}\mathrm{V} \\
\%\end{array}$ \\
\hline Cerrado & 4,0 & 41 & 5 & 1,0 & 2 & 2 & 72 & 5,0 & 77,0 & 6 \\
Goiabal & 5,0 & 28 & 76 & 1,2 & 23 & 17 & 38 & 41,2 & 79,2 & 52 \\
Milharal & 5,2 & 34 & 118 & 2,8 & 32 & 16 & 31 & 50,8 & 81,8 & 62 \\
\hline
\end{tabular}

1- Realizadas no laboratório de análise de solo do Departamento de Solos e Nutrição de Plantas da ESALQ/USP, Piracicaba, SP.

Tabela 4. Análises químicas de micronutrientes de solo das três áreas de amostragem em São Carlos (SP). ${ }^{1}$

\begin{tabular}{lccccc}
\hline & B & Cu & $\begin{array}{c}\text { Fe } \\
\mathrm{mg} / \mathrm{dm}^{3}\end{array}$ & Mn & Zn \\
\hline Cerrado & 0,27 & 1,1 & 105 & 4,5 & 0,4 \\
Goiabal & 0,22 & 3,1 & 34 & 4,7 & 4,9 \\
Milharal & 0,25 & 2,5 & 39 & 20,4 & 6,2 \\
\hline
\end{tabular}

1- Realizadas no laboratório de análise de solo do Departamento de Solos e Nutrição de Plantas da ESALQ/USP, Piracicaba, SP.

\subsection{Coletas de amostras}

A primeira amostragem foi realizada no período de 19 a 21 de maio de 1999 e a segunda de 13 a 15 de fevereiro de 2000. Na Tabela 5, são apresentados dados climáticos obtidos durante os anos em que foram realizadas coletas de amostras.

Em cada amostragem foram coletadas 10 amostras em cada área estudada. Cada amostra foi composta de três subamostras, ou seja, o material retirado de três pontos de 
coleta constituiu uma amostra do tipo composta. No caso da área de vegetação nativa, os três pontos de coleta para composição de cada amostra composta foram localizados ao redor de uma mesma planta, por tratar-se de uma área mais heterogênea, principalmente em relação a espécies de plantas e ambiente. Portanto, em cada área (que foi delimitada em lha cada uma), foram utilizados 30 pontos de coleta em cada amostragem. Segundo Barker (1985), cuja metodologia de coleta é amplamente aceita, recomenda-se utilizar 20-30 pontos de coleta para áreas de 1-2ha.

Após a finalização das identificações taxonômicas dos nematóides presentes nas amostras coletadas, foram preparados gráficos representativos dos números acumulados de famílias ou gêneros de nematóides em relação ao número de amostras coletadas, considerando as duas épocas de amostragem, para se determinar a suficiência das amostragens. Gráficos que relacionam o número de taxa encontrados com o "esforço amostral" são fartamente estudados em ecologia, com esse mesmo objetivo (Brewer, 1994; Goodell, 1982; Krebs, 1994; Magurran, 1988).

Cada amostra foi constituída de $2000 \mathrm{~cm}^{3}$ de solo (da rizosfera das plantas) e $20 \mathrm{~g}$ de raizes. No caso de vegetação arbórea, as amostras foram retiradas de pontos próximos à linha de projeção da copa, onde as raízes mais jovens e ativas podem ser encontradas (Barker, 1985; Fortuner, 1991). Em cada ponto de coleta, foram tomadas amostras na faixa de profundidade de $0-30 \mathrm{~cm}$. Em agroecossistemas, a maioria dos nematóides são encontrados na faixa de $15-20 \mathrm{~cm}$ abaixo da superficie do solo (Norton \& Niblack, 1991). Um enxadão foi usado para retirada das amostras, as quais foram acondicionadas em embalagens plásticas. A extração de nematóides foi realizada logo após cada coleta.

$\mathrm{Na}$ primeira amostragem, a cultura de milho estava com 90 dias após a semeadura (fase de maturação fisiológica ou ponto de silagem). Na segunda amostragem, essa cultura estava com 45 dias após a semeadura (fase de crescimento vegetativo). $\mathrm{Na}$ área de cultivo de milho foi realizada rotação com Crotalaria spectabilis L., no período entre a primeira e a segunda amostragem. 
Tabela 5. Dados climáticos mensais de temperaturas máximas (Tmáx), temperaturas mínimas (Tmín), temperaturas médias (Tmédia) e precipitação pluviométrica $(\mathrm{Pp})$ em São Carlos (SP), obtidos durante os anos em que foram realizadas coletas de amostras de solo e raízes para estudo de diversidade de nematóides. ${ }^{1}$

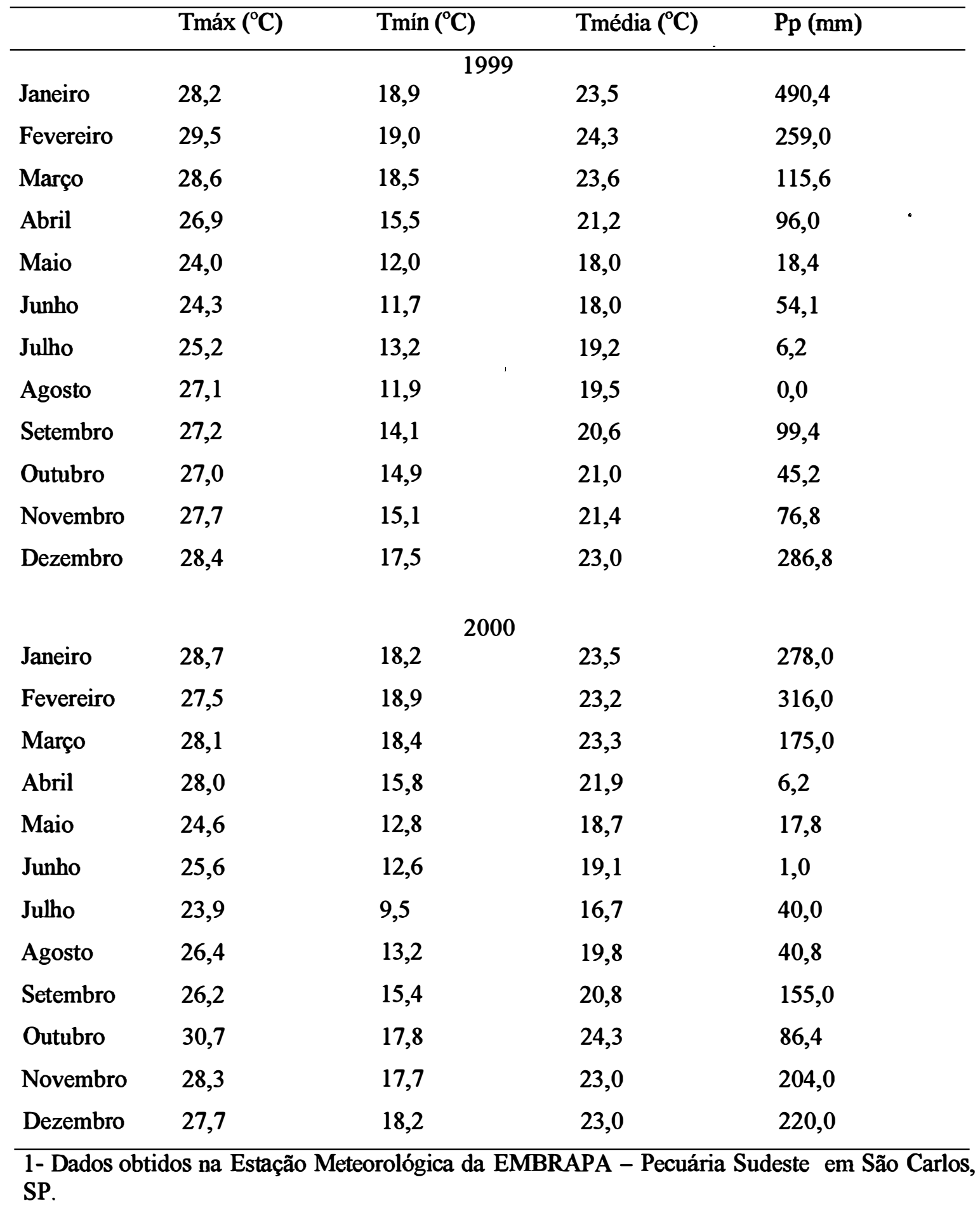




\subsection{Extração de nematóides}

Após as coletas de amostras, as etapas subseqüentes do trabalho foram desenvolvidas no Setor de Nematologia do Departamento de Entomologia, Fitopatologia e Zoologia Agrícola da ESALQ/USP (Piracicaba, SP), começando pela extração de nematóides. Para as amostras de solo, foi utilizado o método de peneiramento seguido de centrifugação em solução de sacarose (Jenkins, 1964). Após homogenização do solo de cada amostra, foi tomada uma alíquota de $200 \mathrm{ml}$ de solo, que foi submetida, em suspensão aquosa, a peneiramento sucessivo através das peneiras de 20 "mesh" (abertura de malha de 0,840mm) e 400 "mesh" (abertura de malha de 0,037mm). Em seguida, o material foi centrifugado por 5 minutos a 1750rpm e por 1 minuto, em solução de sacarose (densidade: 1,15), na mesma rotação. Para extração dos nematóides das raízes, foi utilizado o método de Coolen \& D'Herde (1972). Primeiramente, as raízes foram picadas com tesoura, em pedaços de aproximadamente $1 \mathrm{~cm}$ de comprimento. Em seguida, cada amostra de raízes foi homogeneizada manualmente e foram retirados $5 \mathrm{~g}$ de raízes para extração por meio de fragmentação em liqüidificador seguida de peneiramento e centrifugação. Foi feito o peneiramento da mesma maneira que no caso das amostras de solo, com exceção de que foi adicionada a peneira de 100 "mesh" entre as peneiras de 20 e 400 "mesh". O material retido na peneira de 100 "mesh" foi observado sob microscópio estereoscópico para verificação da presença de fềmeas de Meloidogyne. Após a extração, os exemplares em suspensão foram mortos por aquecimento gradual até $65^{\circ} \mathrm{C}$ e fixados em formalina $2 \%$ ou em glicerina pelo método lento (Hooper, 1986).

\subsection{Identificações e abundâncias de taxa}

Após a extração de nematóides, foi iniciado o trabalho de identificações taxonômicas. Foram adotadas as propostas de identificação sistemática de Maggenti (1991) e Maggenti et al. (1987) para a ordem Tylenchida, de Jairajpuri e Ahmad (1992) para as ordens Dorylaimida e Triplonchida (exceto no caso da família Longidoridae, que foi posicionada como foi proposto por Maggenti, 1991), de Jairajpuri e Khan (1981) para a ordem Mononchida e de Andrássy (1976) para as demais ordens. Dois tipos de 
lâminas foram examinadas em microscópio óptico: lâminas temporárias (formalina) e/ou permanentes (glicerina). Foram identificados gêneros e/ou espécies de nematóides fitoparasitos obrigatórios, isto é, os nematóides que pertencem às seguintes famílias: Longidoridae, Trichodoridae, Dolichodoridae, Belonolaimidae, Pratylenchidae, Hoplolaimidae, Heteroderidae, Criconematidae e Tylenchulidae. Em relação aos nematóides fitoparasitos facultativos (Anguinidae, Aphelenchoididae), as identificações também foram realizadas até nível de gênero. Nematóides da família Tylenchidae foram identificados somente até o nível de família. Esses nematóides podem ser considerados de vida livre ou fitoparasitos somente ocasionais, pois se alimentam em geral de fungos, algas, líquens ou musgos no solo, podendo eventualmente nutrir-se de pelos radiculares de plantas (Siddiqi, 2000; Yeates, 1998; Yeates et al., 1993). Os nematóides de vida livre foram classificados até o nível de família e/ou gênero. Os hábitos alimentares foram determinados com base na bibliografia (especialmente Yeates et al., 1993).

As identificações foram realizadas por meio de estudos morfológicos (qualitativos e biométricos) e consulta a chaves taxonômicas, com auxílio da seguinte literatura básica: Thorne (1961); Goodey (1963); Lordello (1965); Monteiro (1970); Heyns (1971); Andrássy (1976); Kirjanova \& Krall (1977); Krall (1990); Jairajpuri \& Khan (1981); Maggenti (1981); Andrássy (1983); Nickle (1991); Jairajpuri \& Ahmad (1992); Hunt (1993); Decraemer (1995); May \& Mullin (1996); Tihohod (1997); Cares \& Huang (2000); Siddiqi (2000); Cares \& Huang (2001). Também foram preparados cadernos de identificação, por meio de: levantamento atualizado de grupos taxonômicos; obtenção de cópias xerográficas das chaves taxonômicas, descrições e redescrições dos diferentes grupos taxonômicos; compilação do material.

Foram obtidos dados quantitativos (número de indivíduos, ou seja, densidade de cada toxon). Em terminologia ecológica, a densidade é chamada de abundância (Odum, 1988; Silveira Neto et al., 1976; Southwood, 1968). As abundâncias de cada toxon de nematóide presente nas amostras foram estimadas por meio de contagem de exemplares em câmara de Peters, sob microscópio óptico. Essa contagem foi realizada em alíquotas de $50 \%$ das suspensões obtidas após as extrações. 


\subsection{Análise de dados}

\subsubsection{Abundância}

A abundância de cada taxon (família ou gênero) nas comunidades foi avaliada através das estimativas de abundância absoluta e relativa.

\subsubsection{Abundância absoluta}

A abundância absoluta é o número de indivíduos de um determinado taxxon de nematóide em uma amostra ou a média desse número para um grupo de amostras. Foram selecionados alguns gêneros (chamados de gêneros-chave por Mattos, 1999) que possibilitaram, de forma consistente, distinção entre áreas com base nas abundâncias absolutas em amostras de solo+raízes, nas duas épocas de amostragem. Considerando os grupos selecionados, as médias das abundâncias absolutas foram comparadas entre as áreas estudadas e para cada amostragem, com utilização do teste de Duncan ao nível de $5 \%$ de probabilidade e transformação de dados para $\log (x+1)$. Com o mesmo objetivo, foram selecionadas também a família Criconematidae e a superfamília Criconematoidea, grupos taxonômicos que possibilitaram distinção entre a área de vegetação nativa e as áreas cultivadas, como em outros estudos semelhantes (Cares \& Huang, 1991; Mattos, 1999), sendo realizadas comparações de médias das abundâncias absolutas do mesmo modo.

\subsubsection{Abundância relativa}

A abundância relativa (Ar\%) é calculada pela fórmula seguinte, de acordo com Norton (1978):

$$
\mathrm{Ar} \%=\frac{\mathrm{A} \times 100}{\mathrm{~N}}
$$

em que: $\mathbf{A}$ = abundância absoluta, ou seja, número de indivíduos de um determinado taxon em uma amostra;

$\mathrm{N}=$ número total de indivíduos em uma amostra. 


\subsubsection{Freqüência de ocorrência de taxa}

\subsubsection{Frequiência absoluta}

A freqüência absoluta (\%) de ocorrência de um toxon de nematóide é calculada pela fórmula (Norton, 1978):

$$
\text { Freq. absoluta }=\frac{\mathrm{nax} 100}{\mathrm{Na}}
$$

em que: na = número de amostras em que determinado toxon de nematóide ocorreu; $\mathrm{Na}=$ número total de amostras coletadas em determinada área ou tipo de cobertura vegetal.

\subsubsection{Freqüência relativa}

A freqüência relativa (\%) de ocorrência de um determinado toxon de nematóide é calculada pela fórmula (Norton, 1978):

$$
\text { Freq. relativa }=\frac{\text { Freq. absoluta } \times 100}{\mathrm{Sf}}
$$

em que: Freq. absoluta = freqüência absoluta de ocorrência de um determinado toxon; Sf = soma das freqüências absolutas de ocorrência de todos os taxa em determinada área ou tipo de cobertura vegetal.

\subsubsection{Valor de proeminência}

\subsubsection{Valor de proeminência absoluto}

Como abundância e freqüência fornecem diferentes informações sobre populações, Beals ${ }^{1}$ citado por Norton (1978) relacionou essas duas medidas, no valor de proeminência absoluto, que é dado pela abundância absoluta multiplicada pela raiz quadrada da freqüência absoluta de um determinado toxon.

\footnotetext{
${ }^{1}$ BEALS, E. Forest bird communities in the Apostle Islands of Wisconsin. Wilson Bullettin, v.72, p.156-181, 1960.
} 


\subsubsection{Valor de proeminência relativo}

Foi calculado o valor de proeminência relativo (VP\%), como proposto por Huang \& Cares (1995), com utilização da seguinte fórmula:

$$
\mathrm{VP} \%=\frac{\mathrm{VP} \times 100}{\mathrm{Svp}}
$$

em que: $\mathrm{VP}$ = valor de proeminência absoluto de um determinado taxon;

Svp = soma dos valores de proeminência absolutos de todos os taxa em determinada área ou tipo de cobertura vegetal.

\subsubsection{Similaridade entre áreas}

\subsubsection{1 Índice de similaridade de Jaccard}

Foi utilizado o índice de similaridade de Jaccard (Isj) citado por Norton (1978), conforme a fórmula seguinte:

$$
\text { Isj }=\frac{c}{a+b+c}
$$

em que: $\mathrm{a}=$ número de toxa presentes apenas na área "a";

$\mathrm{b}=$ número de taxa presentes apenas na área " $\mathrm{b}$ ";

$\mathrm{c}=$ número de taxa presentes tanto em "a" como em " $\mathrm{b}$ ".

Esse índice varia de 0 a 1 e é tanto maior quanto mais taxa em comum há entre duas áreas comparadas. 


\subsubsection{2 Índice de similaridade de Bray \& Curtis}

Como o índice de Jaccard é baseado apenas na presença ou ausência de nematóides, foi utilizado também o índice de Bray \& Curtis (C), que é baseado em valores quantitativos de abundâncias absolutas, obtido pela fórmula (Bray \& Curtis, 1957):

$$
C=\frac{2 w}{a+b}
$$

em que: $\mathrm{w}$ = soma dos menores valores de abundâncias de nematóides que as comunidades comparadas têm em comum;

$$
\mathrm{a}=\text { abundância total na comunidade " } \mathrm{a} \text { "; }
$$

$\mathrm{b}$ = abundância total na comunidade " $\mathrm{b}$ ".

Esse índice varia de 0 a 1 e é tanto maior quanto maior é a similaridade entre duas áreas comparadas, em relação às comunidades de nematóides.

\subsubsection{Medidas de diversidade}

Para cada área foram utilizadas algumas medidas de diversidade na comunidade de nematóides: riqueza e índices de diversidade (índice de Shannon-Weaver e de eqüitabilidade). Os índices de diversidade foram obtidos com base na diversidade de famílias nas comunidades de nematóides, pois esse foi o nível taxonômico atingido em todas as identificações realizadas. Os índices de diversidade taxonômica, diferentemente das demais medidas adotadas nesse estudo, somente podem ser aplicados para um mesmo nível taxonômico, ao qual todos os espécimens examinados, sem exceção, são classificados (Krebs, 1989; Magurran, 1988). 


\subsubsection{Riqueza}

Foi utilizada uma medida simples e comum de diversidade, que é a riqueza: número de taxa (famílias ou gêneros) de nematóides que ocorreram em cada área estudada (Hunter Jr., 1996).

\subsubsection{2 Índice de Shannon-Weaver}

Foi utilizado o índice de Shannon-Weaver $\left(\mathrm{H}^{\prime}\right)$ para as famílias de nematóides, que é uma conhecida medida de diversidade ecológica, assim obtido (Shannon \& Weaver, 1949):

$$
\mathrm{H}^{\prime}=-\Sigma\left(\mathrm{n}_{i} / \mathrm{N}\right) \log \left(\mathrm{n}_{i} / \mathrm{N}\right) \quad \text { ou } \quad-\Sigma \mathrm{P}_{i} \log \mathrm{P}_{i}
$$

em que: $\mathbf{n}_{i}=$ abundância absoluta de cada toxxon;

$\mathrm{N}=$ soma das abundâncias absolutas de todos os taxa ou número total de indivíduos;

$\mathrm{P}_{i}=$ probabilidade de importância de cada toxon $=\mathrm{n}_{i} / \mathrm{N}$.

Quanto maior o índice H', maior a diversidade na área considerada.

\subsubsection{3 Índice de eqüitabilidade}

Foi utilizado o índice de eqüitabilidade ou uniformidade, para as famílias de nematóides, que é obtido pela fórmula a seguir (Pielou citado por Odum, 1988):

$$
\mathbf{J}=\frac{\mathbf{H}^{\prime}}{\operatorname{Tog} \mathrm{S}}
$$

em que: $\mathrm{H}^{\prime}$ = índice de Shannon-Weaver;

$\mathrm{S}=$ número de toxa . 
$\mathrm{O}$ índice $\mathrm{J}$ ' varia de 0 a $1 \mathrm{e}$, quanto maior o seu valor, maior a uniformidade ou eqüitabilidade dos taxa na área considerada, em relação a suas abundâncias relativas.

\subsubsection{Hábitos alimentares}

Os hábitos alimentares dos nematóides identificados foram determinados com base na bibliografia (especialmente Yeates et al., 1993), obtendo-se a seguinte classificação: fitoparasitos; bacteriófagos; micófagos; predadores; onívoros; predadores ou onívoros (Yeates, 1998; Yeates et al., 1993). Dessa maneira, foram obtidos dados de abundâncias relativas (\%) dos nematóides de cada um desses hábitos alimentares.

Foi utilizado um índice de diversidade trófica $(\mathrm{T})$ com base nas abundâncias relativas (\%) de nematóides dos diferentes grupos tróficos ou hábitos alimentares, que é calculado pela seguinte fórmula (Freckman \& Ettema, 1993):

$$
\mathrm{T}=1 / \Sigma\left(\mathrm{n}_{i} / \mathrm{N}\right)^{2} \quad \text { ou } \quad 1 / \Sigma \mathrm{P}_{i}^{2}
$$

em que: $\mathrm{n}_{i}=$ abundância absoluta de cada gnupo trófico;

$\mathrm{N}=$ soma das abundâncias absolutas de todos os grupos tróficos ou número total de indivíduos;

$\mathbf{P}_{i}=$ probabilidade de importância de cada grupo trófico $=\mathrm{n}_{i} / \mathrm{N}$.

Os dados de abundâncias relativas de nematóides de cada um dos hábitos alimentares foram analisados com uso do teste de Duncan, ao nível de $5 \%$ de probabilidade, com dados transformados para arco seno da raiz quadrada de $\mathrm{x} / 100$, para comparações entre áreas, com base nas médias de abundâncias relativas de cada hábito alimentar. Segundo Pimentel Gomes (1987), nos casos de dados de porcentagem, relativos a uma parte sobre o todo, é necessária a transformação de dados para arco seno da raiz quadrada de $x / 100$. 


\subsection{7 Índices de maturidade}

Foram utilizados índices de maturidade, que podem ser aplicados como medidas de perturbação ambiental e são baseados nas comunidades de nematóides. Os índices de maturidade incorporam características ecológicas das famílias de nematóides, de acordo com uma escala que atribui valores de 1 a 5 (valor c-p) para famílias de nematóides. Valores c-p mais próximos de 1 são atribuídos a nematóides considerados "colonizadores" e valores mais próximos de 5 são atribuídos a nematóides considerados "persistentes" (Bongers, 1990). O índice de maturidade (IM) é obtido pela seguinte fórmula, de acordo com Bongers (1990), considerando apenas os nematóides não fitoparasitos:

$$
\mathrm{IM}=\mathrm{v}_{i} \times\left(\mathrm{n}_{i} / \mathrm{N}\right) \quad \text { ou } \quad \mathrm{v}_{i} \times \mathrm{P}_{i}
$$

em que: $\mathrm{v}_{i}=$ valor $\mathrm{c}-\mathrm{p}$ atribuído à família considerada;

$\mathrm{n}_{i}=$ abundância absoluta da família considerada;

$\mathrm{N}$ = soma das abundâncias absolutas de todas as famílias ou número total de indivíduos;

$\mathbf{P}_{i}=$ probabilidade de importância de cada família $=\mathrm{n}_{i} / \mathrm{N}$.

Foram utilizados também os seguintes índices: índice de parasitos de plantas (IPP), que é obtido pela mesma fórmula, porém considerando apenas os nematóides fitoparasitos (Bongers, 1990); índice de maturidade modificado ( $\mathrm{MM})$, que foi proposto por Yeates (1994), sendo obtido pela mesma fórmula, porém considerando os nematóides de todos os hábitos alimentares presentes na comunidade. 


\section{RESULTADOS E DISCUSSÃO}

\subsection{Posição sistemática dos nematóides encontrados}

Filo NEMATA (Cobb, 1919) Chitwood, 1958

I. Classe ADENOPHOREA (von Linstow, 1905) Chitwood, 1958

Ordem TRIPLONCHIDA Cobb, 1920

Subordem DIPHTHEROPHORINA Coomans \& Loof, 1970

Superfamília Diphtherophoroidea (Micoletzky, 1922) Clark, 1961

Família Diphtherophoridae (Micoletzky, 1922) Thorne, 1935

Subfamília Diphtherophorinae Thorne, 1935

Gênero Diphtherophora de Man, 1880

Superfamília Trichodoroidea (Thorne, 1935) Siddiqi, 1974

Família Trichodoridae (Thorne, 1935) Siddiqi, 1961

Subfamília Trichodorinae Thorne, 1935

Gênero Paratrichodorus Siddiqi, 1974

Espécie Paratrichodorus minor (Colbran, 1956) Siddiqi, 1974

Ordem ARAEOLAIMIDA de Coninck \& Schuurmanns Stekhoven, 1933

Subordem ARAEOLAIMINA de Coninck \& Schuurmanns Stekhoven, 1933

Superfamília Plectoidea (Örley, 1880) Chitwood, 1937

Família Plectidae Örley, 1880

Subfamília Plectinae (Örley, 1880) Micoletzky, 1922

Gênero Plectus Bastian, 1865 
Gênero Chronogaster Cobb, 1913

Subfamília Wilsonematinae Chitwood, 1951

Gênero Wilsonema Cobb, 1913

Ordem CHROMADORIDA (Filipjev, 1917) Chitwood, 1933

Subordem CHROMADORINA Chitwood \& Chitwood, 1937

Superfamília Chromadoroidea (Filipjev, 1917) Schuurmanns Stekhoven \& de Coninck, 1933

Família Chromadoridae Filipjev, 1917

Subordem CYATHOLAIMINA de Coninck, 1965

Superfamília Cyatholaimoidea Filipjev, 1918

Família Cyatholaimidae (Filipjev, 1918) de Coninck \& Schuurmanns

Stekhoven, 1933

Subfamília Cyatholaiminae (Filipjev, 1918) Micoletzky, 1922

Gênero Odontolaimus de Man, 1880

Gênero Achromadora Cobb, 1913

Ordem ENOPLIDA (Baird, 1853) Chitwood, 1933

Subordem TRIPYLINA Andrássy, 1974

Superfamília Ironoidea de Man, 1876

Família Ironidae de Man, 1876

Subfamília Ironinae (de Man, 1876) Micoletzky, 1922

Gênero Ironus Bastian, 1865

Superfamília Oxystominoidea Filipjev, 1918

Família Alaimidae Micoletzky, 1922 incertae sedis

Subfamília Alaiminae Micoletzky, 1922

Gênero Alaimus de Man, 1880 
Ordem MONHYSTERIDA (Örley, 1880) de Coninck \& Schuurmanns Stekhoven, 1933

Subordem MONHYSTERINA de Coninck \& Schuurmanns Stekhoven, 1933

Superfamília Monhysteroidea de Man, 1876

Família Monhysteridae (Örley, 1880) de Man, 1876

Subfamília Monhysterinae (Örley, 1880) Micoletzky, 1922

Gênero Monhystera Bastian, 1865

Gênero Prismatolaimus de Man, 1880 incertae sedis

Ordem DORYLAIMIDA Pearse, 1942

Subordem DORYLAIMINA (Chitwood, 1933) Pearse, 1936

Superfamília Dorylaimoidea (de Man, 1876) Thorne, 1934

Família Dorylaimidae de Man, 1876

Subfamília Laimydorinae Andrássy, 1969

Gênero Mesodorylaimus Andrássy, 1959

Gênero Amphydorylaimus Andrássy, 1960

Subfamília Thornenematinae Siddiqi, 1969

Gênero Opisthodorylaimus Ahmad \& Jairajpuri, 1982

Família Longidoridae (Thorne, 1935) Meyl, 1961

Subfamília Xiphinematinae Dalmasso, 1969

Gênero Xiphinema Cobb, 1913

Família Aporcelaimidae Heyns, 1965

Subfamília Aporcelaiminae (Heyns, 1965) Siddiqi, 1969

Gênero Aporcelaimellus Heyns, 1965

Família Qudsianematidae (Jairajpuri, 1965) Siddiqi, 1969

Subfamília Qudsianematinae Jairajpuri, 1965

Gênero Labronema Thorne, 1939

Gênero Eudorylaimus Andrássy, 1959

Gênero Ecumenicus Thorne, 1974

Gênero Microdorylaimus Andrássy, 1986

Subfamília Discolaiminae Siddiqi, 1969 
Gênero Discolaimus Cobb, 1913

Gênero Discolaimium Thorne, 1939

Gênero Mylodiscus Thorne, 1939

Gênero Discolaimoides Heyns, 1963

Família Nordiidae (Jairajpuri \& A.H. Siddiqi, 1964) Siddiqi, 1969

Subfamília Pungentinae Siddiqi, 1969

Gênero Enchodelus Thorne, 1939

Subfamília Actinolaimoidinae Jairajpuri \& Ahmad, 1992

Gênero Oriverutus Siddiqi, 1971

Superfamília Actinolaimoidea Thorne, 1939

Família Actinolaimidae Thorne, 1939

Subfamília Paractinolaiminae Thorne, 1969

Gênero Paractinolaimus Meyl, 1957

Família Carcharolaimidae Thorne, 1967

Subfamília Carcharolaiminae Thorne, 1967

Gênero Carcharolaimus Thorne, 1939

Superfamília Belondiroidea Thorne, 1939

Família Belondiridae Thorne, 1939

Subfamília Belondirinae Thorne, 1939

Gênero Belondira Thorne, 1939

Gênero Axonchium Cobb, 1920

Gênero Dactyluraxonchium Coomans \& Nair, 1975

Subfamília Dorylaimellinae Jairajpuri, 1964

Gênero Dorylaimellus Cobb, 1913

Superfamília Tylencholaimoidea Filipjev, 1934

Família Tylencholaimidae (Filipjev, 1934) Siddiqi, 1969

Subfamília Tylencholaiminae Filipjev, 1934

Gênero Tylencholaimus de Man, 1876

Gênero Chitwoodius Furstenberg \& Heyns, 1966

Família Leptonchidae Thorne, 1935 
Subfamília Leptonchinae Thorne, 1935

Gênero Leptonchus Cobb, 1920

Gênero Meylis Goseco, Ferris \& Ferris, 1974

Subfamília Tyleptinae Jairajpuri, 1964

Gênero Tyleptus Thorne, 1939

Subfamília Belonenchinae Thorne, 1964

Gênero Basirotyleptus Jairajpuri, 1964

Gênero Glochidorella Siddiqi, 1982

Subfamília Tylencholaimellinae Jairajpuri, 1964

Gênero Tylencholaimellus M.V. Cobb, 1915

Família Mydonomidae Thorne, 1964

Subfamília Mydonominae Thorne, 1964

Gênero Dorylaimoides Thorne \& Swanger, 1936

Subordem NYGOLAIMINA Ahmad \& Jairajpuri, 1979

Superfamília Nygolaimoidea Thorne, 1935

Família Nygolaimidae Thorne, 1935

Família Nygolaimellidae Clark, 1961

Subfamília Nygolaimellinae Clark, 1961

Gênero Nygolaimellus Loos, 1949

Ordem MONONCHIDA Jairajpuri, 1969

Subordem MONONCHINA Kirjanova \& Krall, 1969

Superfamília Mononchoidea Chitwood, 1937

Família Mononchidae Chitwood, 1937

Subfamília Mononchinae Chitwood, 1937

Gênero Mononchus Bastian, 1865

Subfamília Prionchulinae Andrássy, 1976

Gênero Prionchulus (Cobb, 1916) Wu \& Hoeppli, 1929

Gênero Clarkus Jairajpuri, 1970

Família Mylonchulidae Jairajpuri, 1969 
Subfamília Mylonchulinae Jairajpuri, 1969

Gênero Mylonchulus (Cobb, 1916) Altherr, 1953

Subfamília Sporonchulinae Jairajpuri, 1969

Gênero Sporonchulus (Cobb, 1917) Andrássy, 1958

II. Classe SECERNENTEA Chitwood, 1958

Ordem RHABDITIDA (Örley, 1880) Chitwood, 1933

Subordem RHABDITINA (Örley, 188) Chitwood, 1933

Superfamília Rhabditoidea Örley, 1880

Família Rhabditidae Örley, 1880

Subfamília Mesorhabditinae Andrássy, 1976

Gênero Mesorhabditis (Osche, 1952) Dougherty, 1953

Gênero Cruznema Artigas, 1927

Subfamília Rhabditinae Örley, 1880

Gênero Rhabditis Dujardin, 1845

Subordem CEPHALOBINA Andrássy, 1974

Superfamília Cephaloboidea Filipjev, 1934

Família Cephalobidae (Filipjev, 1934) Chitwood \& Chitwood, 1934

Subfamília Cephalobinae Filipjev, 1934

Gênero Cephalobus Bastian, 1865

Gênero Eucephalobus Steiner, 1936

Subfamília Acrobelinae Thorne, 1937

Gênero Acrobeles Linstow, 1877

Gênero Acrobeloides (Cobb, 1924) Thorne, 1937

Gênero Chiloplacus Thorne, 1937

Gênero Zeldia Thorne, 1937

Superfamília Panagrolaimoidea Thorne, 1937

Família Panagrolaimidae Thorne, 1937 
Subfamília Panagrolaiminae Thorne, 1937

Gênero Panagrolaimus Fuchs, 1930

Subordem TERATOCEPHALINA Andrássy, 1974 incertae sedis

Superfamília Teratocephaloidea Andrássy, 1958

Família Teratocephalidae Andrássy, 1958

Subfamília Metateratocephalinae Eroshenko, 1973

Gênero Euteratocephalus Andrássy, 1958

Ordem TYLENCHIDA Thorne, 1949

Subordem TYLENCHINA Chitwood, 1950

Superfamília Tylenchoidea Örley, 1880

Família Tylenchidae Örley, 1880

Família Anguinidae Nicoll, 1935 (1926)

Subfamília Anguininae Nicoll, 1935 (1926)

Gênero Ditylenchus Filipjev, 1936

Família Hoplolaimidae (Filipjev, 1934) Wieser, 1953

Subfamília Hoplolaiminae Filipjev, 1934

Gênero Aorolaimus Sher, 1963

Gênero Helicotylenchus Steiner, 1945

Espécie Helicotylenchus dihystera (Cobb, 1893) Sher, 1961

Família Pratylenchidae (Thorne, 1949) Siddiqi, 1963

Subfamília Pratylenchinae Thorne, 1949

Gênero Pratylenchus Filipjev, 1936

Espécie Pratylenchus brachyurus (Godfrey, 1929) Filipjev \&

Schuurmanns Stekhoven, 1941

Espécie Pratylenchus zeae Graham, 1951

Superfamília Criconematoidea Taylor, 1936

Família Criconematidae (Taylor, 1936) Thorne, 1949

Subfamília Criconematinae Taylor, 1936

Gênero Criconemella De Grisse \& Loof, 1965 
Gênero Discocriconemella De Grisse \& Loof, 1965

Gênero Hemicriconemoides Chitwood \& Birchfield, 1957

Subfamília Hemicycliophorinae Skarbilovich, 1959

Gênero Hemicycliophora de Man, 1921

Família Tylenchulidae (Skarbilovich, 1947) Kirjanova, 1955

Subfamília Tylenchulinae Skarbilovich, 1947

Gênero Tylenchulus Cobb, 1913

Subfamília Paratylenchinae Thorne, 1949

Gênero Paratylenchus Micoletzky, 1922

Subordem APHELENCHINA Geraert, 1966

Superfamília Aphelenchoidea (Fuchs, 1937) Thorne, 1949

Família Aphelenchidae (Fuchs, 1937) Steiner, 1949

Subfamília Aphelenchinae Fuchs, 1937

Gênero Aphelenchus Bastian, 1865

Famíla Paraphelenchidae (T. Goodey, 1951) J.B. Goodey, 1960

Subfamília Paraphelenchinae T. Goodey, 1951

Gênero Paraphelenchus Micoletzky, 1925

Superfamília Aphelenchoidoidea (Skarbilovich, 1947) Siddiqi, 1980

Família Aphelenchoididae (Skarbilovich, 1947) Paramonov, 1953

Subfamília Aphelenchoidinae Skarbilovich, 1947

Gênero Aphelenchoides Fischer, 1894

\subsection{Identificações taxonômicas}

As identificações taxonômicas realizadas em relação aos nematóides encontrados em amostras de solo ou raízes de cada uma das áreas amostradas estão nas Tabelas 6, 7 e 8. Os nematóides fitoparasitos foram identificados até nível de gênero e/ou espécie, enquanto que os nematóides de vida livre foram identificados até nível de família e/ou gênero. Para a área de cerrado, foram identificados nematóides pertencentes a duas classes (Adenophorea e Secernentea), oito ordens (Araeolaimida, Dorylaimida, Enoplida, Monhysterida, Mononchida, Triplonchida, Rhabditida e Tylenchida), 17 
superfamílias, 30 famílias, 58 gêneros e três espécies (Paratrichodorus minor, Pratylenchus brachyurus e $P$. zeae). Para a área de goiabal, foram identificados nematóides pertencentes a duas classes (Adenophorea e Secernentea), nove ordens (Araeolaimida, Chromadorida, Dorylaimida, Enoplida, Monhysterida, Mononchida, Triplonchida, Rhabditida, Tylenchida), 19 superfamílias, 32 famílias, 49 gêneros e três espécies (Helicotylenchus dihystera, Paratrichodorus minor e Pratylenchus brachyurus, sendo que essa última espécie não foi observada em solo, apenas em raízes). Para a área de milharal, foram identificados nematóides pertencentes a duas classes (Adenophorea e Secernentea), nove ordens (Araeolaimida, Chromadorida, Dorylaimida, Enoplida, Monhysterida, Mononchida, Triplonchida, Rhabditida e Tylenchida), 19 superfamílias, 29 famílias, 46 gêneros e quatro espécies (Helicotylenchus dihystera, Paratrichodorus minor, Pratylenchus brachyurus e $P$. zeae). Em relação à ordem Tylenchida, em todas as três áreas amostradas foram encontrados representantes das duas subordens, Aphelenchina e Tylenchina.

A presença ou ausência de nematóides pode ser considerada para comparação entre as áreas estudadas. A "ausência" deve ser considerada, na realidade, como presença não detectada pela amostragem, métodos de extração e de estimativas de abundâncias (contagem em alíquota de $50 \%$ da suspensão obtida após a extração). Os seguintes nematóides tiveram presença detectada em todas as áreas amostradas: Acrobeles, Acrobeloides, Aphelenchus, Aporcelaimellus, Axonchium, Cephalobus, Chiloplacus, Chitwoodius, Criconemella, Diphtherophora, Discolaimium, Discolaimoides, Ditylenchus, Dorylaimellus, Eucephalobus, Eudorylaimus, Helicotylenchus, Mesodorylaimus, Mononchus, Mylonchulus, Opisthodorylaimus, Paraphelenchus, Paratrichodorus, Plectus, Pratylenchus, Prismatolaimus, Rhabditis e Xiphinema. Esses nematóides, por estarem presentes em todas as áreas estudadas, tiveram condições de sobreviver mesmo após a retirada da vegetação original de cerrado e o estabelecimento de cultivos agrícolas (milho e goiabeira). Nematóides que tiveram presença detectada em cerrado, mas não nas duas áreas cultivadas, provavelmente são mais sensíveis às modificações ambientais devidas ao uso agrícola da terra (Yeates, 1991); foram os seguintes: Aorolaimus, Basirotyleptus, Clarkus, Discocriconemella, 
Glochidorella, Hemicriconemoides, Paratylenchus, Tylenchulus e Tyleptus. Dentre esses nematóides, quatro são da superfamília Criconematoidea (Discocriconemella, Hemicriconemoides, Paratylenchus e Tylenchulus), que congrega nematóides em geral mais sensíveis a modificações devidas ao cultivo (Mattos, 1999; Yeates, 1991) e um deles é da ordem Mononchida (Clarkus), cujos nematóides, juntamente com outros predadores, também têm sido considerados, por alguns autores, relativamente sensíveis a alterações ambientais (Niles \& Freckman, 1998; Wasilewska, 1997; Yeates \& Bongers, 1999). Nematóides que tiveram presença detectada nas duas áreas cultivadas, mas não em cerrado, podem ter sido favorecidos ou introduzidos com o uso agrícola da terra (Yeates, 1991); estes foram: Aphelenchoides, Carcharolaimus, Discolaimus, Monhystera, Panagrolaimus, Paractinolaimus e Zeldia. Dentre esses nematóides, três são bacteriófagos (Monhystera, Panagrolaimus e Zeldia). Em determinadas situações, nematóides bacteriófagos podem ter suas abundâncias elevadas devido a cultivos agrícolas, principalmente devido à presença de matéria orgânica facilmente degradável (restos culturais) ou adição de adubos nitrogenados (Wasilewska, 1997).

Realizando o mesmo tipo de comparações, porém considerando separadamente cada área cultivada, tem-se o seguinte. Nematóides que tiveram sua presença detectada em cerrado e goiabal, mas não em milharal, podem ser mais sensíveis às mudanças resultantes do sistema de uso da terra estabelecido na área de milharal; foram eles: Alaimus, Dorylaimoides, Enchodelus, Labronema, Leptonchus, Oriverutus, Tylencholaimellus e Wilsonema. Nematóides que tiveram a presença detectada em cerrado e milharal, mas não em goiabal, provavelmente são mais sensíveis às mudanças resultantes do sistema de uso da terra estabelecido na área de goiabal; foram os seguintes: Ecumenicus, Ironus, Nygolaimellus, Prionchulus, Sporonchulus e Tylencholaimus. Nematóides que tiveram presença detectada em goiabal, mas não em cerrado e milharal, podem ter sido favorecidos ou introduzidos com a implantação do cultivo de goiabeira; foram os seguintes: Belondira, Chronogaster, Hemicycliophora e Odontolaimus. Nematóides que tiveram presença detectada em milharal, mas não em cerrado e goiabal, podem ter sido favorecidos ou introduzidos com a implantação do cultivo de milho, tratando-se de: Achromadora e Amphidorylaimus. 0 gênero 
Achromadora reúne espécies de nematóides algívoros que ocorrem em geral em solo úmido ou em águas fluviais (Goodey, 1963; Yeates et al., 1993). Considerando que a área de milharal é irrigada, nematóides do gênero Achromadora podem ter sido trazidos para o local por meio de água de irrigação. A disseminação de nematóides fitoparasitos ou de vida livre por água de irrigação já foi antes verificada (Ferraz \& Oliveira, 1980).

Tabela 6. Identificações taxonômicas de nematóides presentes em amostras coletadas em área de cerrado em São Carlos, SP (amostragens em maio de 1999 e fevereiro de 2000).

\begin{tabular}{lll}
\hline Superfamília & Família & Gênero e/ou espécie \\
\hline \multirow{3}{*}{ Plectoidea } & Classe Adenophorea / Ordem Araeolaimida \\
& Plectidae & Plectus \\
& & Wilsonema \\
Belondiroidea & Classe Adenophorea / Ordem Dorylaimida \\
& Belondiridae & Axonchium \\
& & Dactyluraxonchium \\
Dorylaimoidea & Aporcelaimidae & Aporylaimellus \\
& Dorylaimidae & Mesodorylaimus \\
& & Opisthodorylaimus \\
& Longidoridae & Xiphinema \\
& Nordiidae & Enchodelus \\
& & Oriverutus \\
& Qudsianematidae & Discolaimium \\
& & Discolaimoides \\
& & Ecumenicus \\
& & Eudorylaimus \\
& & Labronema \\
& & Microdorylaimus \\
& & Mylodiscus \\
& & Nygolaimellus \\
& &
\end{tabular}


Tabela 6. Identificações taxonômicas de nematóides presentes em amostras coletadas em área de cerrado em São Carlos, SP (amostragens em maio de 1999 e fevereiro de 2000).

\begin{tabular}{lll}
\hline Superfamília & Familia & Gênero e/ou espécie \\
\hline Tylencholaimoidea & Leptonchidae & Basirotyleptus \\
& & Glochidorella \\
& & Leptonchus \\
& & Meylis \\
& & Tylencholaimellus \\
& Mydonomidae & Tyleptus \\
& Tylencholaimidae & Chitwoodius \\
& & Tylencholaimus \\
& & \\
Ironoidea & Classe Adenophorea / Ordem Enoplida \\
Oxystominoidea & Ironidae & Ironus \\
& Alaimidae & Alaimus \\
& & \\
Monhysteroidea & Classe Adenophorea / Ordem Monhysterida \\
& Monhysteridae & Prismatolaimus \\
& & \\
Trichodoroidea & Classe Adenophorea / Ordem Mononchida \\
Mononchoidea & Mononchidae & Clarkus \\
& & Mononchus \\
& & Prionchulus \\
& & Mylonchulus \\
& & Sporonchulus \\
& Mylonchulidae & \\
& & Paratrichodorus minor \\
& &
\end{tabular}


Tabela 6. Identificações taxonômicas de nematóides presentes em amostras coletadas em área de cerrado em São Carlos, SP (amostragens em maio de 1999 e fevereiro de 2000).

\begin{tabular}{|c|c|c|}
\hline Superfamília & Família & Gênero e/ou espécie \\
\hline \multicolumn{3}{|c|}{ Classe Secernentea / Ordem Rhabditida } \\
\hline \multirow[t]{5}{*}{ Cephaloboidea } & Cephalobidae & Acrobeles \\
\hline & & Acrobeloides \\
\hline & & Cephalobus \\
\hline & & Chiloplacus \\
\hline & & Eucephalobus \\
\hline \multirow[t]{2}{*}{ Rhabditoidea } & Rhabditidae & Cruznema \\
\hline & & Rhabditis \\
\hline \multirow[t]{2}{*}{ Teratocephaloidea } & Teratocephalidae & Euteratocephalus \\
\hline & Classe Secernentea & Tylenchida \\
\hline \multirow[t]{2}{*}{ Aphelenchoidea } & Aphelenchidae & Aphelenchus \\
\hline & Paraphelenchidae & Paraphelenchus \\
\hline \multirow[t]{5}{*}{ Criconematoidea } & Criconematidae & Criconemella \\
\hline & & Discocriconemella \\
\hline & & Hemicriconemoides \\
\hline & Tylenchulidae & Paratylenchus \\
\hline & & Tylenchulus \\
\hline \multirow[t]{6}{*}{ Tylenchoidea } & Anguinidae & Ditylenchus \\
\hline & Hoplolaimidae & Aorolaimus \\
\hline & & Helicotylenchus \\
\hline & Pratylenchidae & Pratylenchus brachyurus \\
\hline & & Pratylenchus zeae \\
\hline & Tylenchidae & \\
\hline
\end{tabular}


Tabela 7. Identificações taxonômicas de nematóides presentes em amostras coletadas em área de goiabal em São Carlos, SP (amostragens em maio de 1999 e fevereiro de 2000).

\begin{tabular}{|c|c|c|}
\hline Superfamília & Família & Gênero e/ou espécie \\
\hline \multicolumn{3}{|c|}{ Classe Adenophorea / Ordem Araeolaimida } \\
\hline \multirow[t]{3}{*}{ Plectoidea } & Plectidae & Chronogaster \\
\hline & & Plectus \\
\hline & & Wilsonema \\
\hline \multicolumn{3}{|c|}{ Classe Adenophorea / Ordem Chromadorida } \\
\hline Chromadoroidea & Chromadoroidea & \\
\hline \multirow[t]{2}{*}{ Cyatholaimoidea } & Cyatholaimidae & Odontolaimus \\
\hline & \multicolumn{2}{|c|}{ Classe Adenophorea / Ordem Dorylaimida } \\
\hline \multirow[t]{2}{*}{ Actinolaimoidea } & Actinolaimidae & Paractinolaimus \\
\hline & Carcharolaimidae & Carcharolaimus \\
\hline \multirow[t]{3}{*}{ Belondiroidea } & Belondiridae & Axonchium \\
\hline & & Belondira \\
\hline & & Dorylaimellus \\
\hline \multirow[t]{12}{*}{ Dorylaimoidea } & Aporcelaimidae & Aporcelaimellus \\
\hline & Dorylaimidae & Mesodorylaimus \\
\hline & & Opisthodorylaimus \\
\hline & Longidoridae & Xiphinema \\
\hline & Nordiidae & Enchodelus \\
\hline & & Oriverutus \\
\hline & Qudsianematidae & Discolaimium \\
\hline & & Discolaimoides \\
\hline & & Discolaimus \\
\hline & & Eudorylaimus \\
\hline & & Labronema \\
\hline & & Microdorylaimus \\
\hline Nygolaimoidea & Nygolaimidae & Nygolaimus \\
\hline \multirow[t]{4}{*}{ Tylencholaimoidea } & Leptonchidae & Leptonchus \\
\hline & & Tylencholaimellus \\
\hline & Mydonomidae & Dorylaimoides \\
\hline & Tylencholaimidae & Chitwoodius \\
\hline
\end{tabular}


Tabela 7. Identificações taxonômicas de nematóides presentes em amostras coletadas em área de goiabal em São Carlos, SP (amostragens em maio de 1999 e fevereiro de 2000).

\begin{tabular}{|c|c|c|}
\hline Superfamília & Família & Gênero e/ou espécie \\
\hline \multicolumn{3}{|c|}{ Classe Adenophorea / Ordem Enoplida } \\
\hline Oxystominoidea & Alaimidae & Alaimus \\
\hline \multicolumn{3}{|c|}{ Classe Adenophorea / Ordem Monhysterida } \\
\hline \multirow[t]{2}{*}{ Monhysteroidea } & Monhysteridae & Monhystera \\
\hline & & Prismatolaimus \\
\hline \multicolumn{3}{|c|}{ Classe Adenophorea / Ordem Mononchida } \\
\hline \multirow[t]{2}{*}{ Mononchoidea } & Mononchidae & Mononchus \\
\hline & Mylonchulidae & Mylonchulus \\
\hline \multicolumn{3}{|c|}{ Classe Adenophorea / Ordem Triplonchida } \\
\hline Diphtherophoroidea & Diphtherophoridae & Diphtherophora \\
\hline \multirow[t]{2}{*}{ Trichodoroidea } & Trichodoridae & Paratrichodorus minor \\
\hline & Classe Secernentea & n Rhabditida \\
\hline \multirow[t]{6}{*}{ Cephaloboidea } & Cephalobidae & Acrobeles \\
\hline & & Acrobeloides \\
\hline & & Cephalobus \\
\hline & & Chiloplacus \\
\hline & & Eucephalobus \\
\hline & & Zeldia \\
\hline Panagrolaimoidea & Panagrolaimidae & Panagrolaimus \\
\hline \multirow[t]{2}{*}{ Rhabditoidea } & Rhabditidae & Rhabditis \\
\hline & Classe Secernentea & n Tylenchida \\
\hline \multirow[t]{3}{*}{ Aphelenchoidea } & Aphelenchidae & Aphelenchus \\
\hline & Aphelenchoididae & Aphelenchoides \\
\hline & Paraphelenchidae & Paraphelenchus \\
\hline \multirow[t]{2}{*}{ Criconematoidea } & Criconematidae & Criconemella \\
\hline & & Hemicycliophora \\
\hline
\end{tabular}


Tabela 7. Identificações taxonômicas de nematóides presentes em amostras coletadas em área de goiabal em São Carlos, SP (amostragens em maio de 1999 e fevereiro de 2000).

\begin{tabular}{lll}
\hline Superfamília & Família & Gênero e/ou espécie \\
\hline Tylenchoidea & Anguinidae & Ditylenchus \\
& Hoplolaimidae & Helicotylenchus dihystera \\
& Pratylenchidae * & Pratylenchus brachyurus * \\
& Tylenchidae & \\
\hline
\end{tabular}

* Constatação apenas em raízes.

Tabela 8. Identificações taxonômicas de nematóides presentes em amostras coletadas em área de milharal em São Carlos, SP (amostragens em maio de 1999 e fevereiro de 2000).

\begin{tabular}{|c|c|c|}
\hline Superfamília & Família & Gênero e/ou espécie \\
\hline \multicolumn{3}{|c|}{ Classe Adenophorea / Ordem Araeolaimida } \\
\hline Plectoidea & Plectidae & Plectus \\
\hline \multicolumn{3}{|c|}{ Classe Adenophorea / Ordem Chromadorida } \\
\hline Cyatholaimoidea & Cyatholaimidae & Achromadora \\
\hline \multicolumn{3}{|c|}{ Classe Adenophorea / Ordem Dorylaimida } \\
\hline \multirow[t]{2}{*}{ Actinolaimoidea } & Actinolaimidae & Paractinolaimus \\
\hline & Carcharolaimidae & Carcharolaimus \\
\hline \multirow[t]{2}{*}{ Belondiroidea } & Belondiridae & Axonchium \\
\hline & & Dorylaimellus \\
\hline \multirow[t]{11}{*}{ Dorylaimoidea } & Aporcelaimidae & Aporcelaimellus \\
\hline & Dorylaimidae & Amphidorylaimus \\
\hline & & Dorylaimus \\
\hline & & Mesodorylaimus \\
\hline & & Opisthodorylaimus \\
\hline & Longidoridae & Xiphinema \\
\hline & Qudsianematidae & Discolaimium \\
\hline & & Discolaimoides \\
\hline & & Discolaimus \\
\hline & & Ecumenicus \\
\hline & & Eudorylaimus \\
\hline
\end{tabular}


Tabela 8. Identificações taxonômicas de nematóides presentes em amostras coletadas em área de milharal em São Carlos, SP (amostragens em maio de 1999 e fevereiro de 2000).

\begin{tabular}{|c|c|c|}
\hline Superfamília & Família & Gênero e/ou espécie \\
\hline Nygolaimoidea & Nygolaimellidae & Nygolaimellus \\
\hline \multirow[t]{4}{*}{ Tylencholaimoidea } & Leptonchidae & \\
\hline & Tylencholaimidae & Chitwoodius \\
\hline & & Tylencholaimus \\
\hline & \multicolumn{2}{|c|}{ Classe Adenophorea / Ordem Enoplida } \\
\hline Ironoidea & Ironidae & Ironus \\
\hline \multicolumn{3}{|l|}{ - } \\
\hline \multicolumn{3}{|c|}{ Classe Adenophorea / Ordem Monhysterida } \\
\hline \multirow[t]{3}{*}{ Monhysteroidea } & Monhysteridae & Monhystera \\
\hline & & Prismatolaimus \\
\hline & Classe Adenophorea & Mononchida \\
\hline \multirow[t]{4}{*}{ Mononchoidea } & Mononchidae & Mononchus \\
\hline & & Prionchulus \\
\hline & Mylonchulidae & Mylonchulus \\
\hline & & Sporonchulus \\
\hline \multicolumn{3}{|c|}{ Classe Adenophorea / Ordem Triplonchida } \\
\hline Diphtherophoroidea & Diphtherophoridae & Diphtherophora \\
\hline \multirow[t]{2}{*}{ Trichodoroidea } & Trichodoridae & Paratrichodorus minor \\
\hline & Classe Secernentea & n Rhabditida \\
\hline \multirow[t]{6}{*}{ Cephaloboidea } & Cephalobidae & Acrobeles \\
\hline & & Acrobeloides \\
\hline & & Cephalobus \\
\hline & & Chiloplacus \\
\hline & & Eucephalobus \\
\hline & & Zeldia \\
\hline Panagrolaimoidea & Panagrolaimidae & Panagrolaimus \\
\hline \multirow[t]{2}{*}{ Rhabditoidea } & Rhabditidae & Mesorhabditis \\
\hline & & Rhabditis \\
\hline
\end{tabular}


Tabela 8. Identificações taxonômicas de nematóides presentes em amostras coletadas em área de milharal em São Carlos, SP (amostragens em maio de 1999 e fevereiro de 2000).

\begin{tabular}{lll}
\hline Superfamília & Família & Gênero e/ou espécie \\
\hline \multirow{3}{*}{ Aphelenchoidea } & Classe Secernentea / Ordem Tylenchida \\
& Aphelenchidae & Aphelenchus \\
& Paraphelenchidae & Paraphelenchus \\
Aphelenchoidoidea & Aphelenchoididae & Aphelenchoides \\
Criconematoidea & Criconematidae & Criconemella \\
- Tylenchoidea & Anguinidae & Ditylenchus \\
& Hoplolaimidae & Helicotylenchus dihystera \\
& Pratylenchidae & Pratylenchus brachyurus \\
& & Pratylenchus zeae \\
& Tylenchidae & \\
\hline
\end{tabular}

\subsection{Abundâncias, freqüências e valores de proeminência}

Os resultados referentes às abundâncias, freqüências e valores de proeminência das famílias e gêneros dos nematóides encontrados em amostras de solo ou raízes (em cada uma das áreas amostradas e em cada época de amostragem) estão apresentados em ANEXOS (página 88).

Em relação às amostras de solo da primeira amostragem (maio de 1999), as dez famílias mais abundantes foram as seguintes (em ordem decrescente de abundâncias), para cerrado (1), goiabal (2) e milharal (3), com respectivas abundâncias relativas (\%) entre parênteses: 1) Qudsianematidae (25,93), Criconematidae (17,37), Tylenchulidae $(10,14)$, Belondiridae $(8,71)$, Cephalobidae $(7,98)$, Leptonchidae $(5,89)$, Mydonomidae $(4,00)$, Hoplolaimidae (3,55), Rhabditidae $(2,19)$ e Aporcelaimidae (1,91); 2) Hoplolaimidae $(48,38)$, Qudsianematidae $(10,78)$, Cephalobidae $(7,84)$, Rhabditidae $(6,79)$, Belondiridae $(5,99)$, Dorylaimidae $(5,19)$, Longidoridae $(3,00)$, Diphtherophoridae $(2,80)$, Tylenchidae $(1,88)$ e Mylonchulidae $(1,58)$; 3) Hoplolaimidae $(30,36)$, Pratylenchidae $(20,61)$, Dorylaimidae $(9,44)$, Qudsianematidae $(9,02)$, Cephalobidae $(8,68)$, Aporcelaimidae $(4,21)$, Tylenchidae $(3,23)$, Nygolaimellidae $(2,42)$, Tylencholaimidae $(2,27)$ e Plectidae $(1,65)$. Os dez gêneros identificados mais 
abundantes, nesse mesmo caso, foram os seguintes: 1) Discocriconemella $(17,70)$, Tylenchulus (10,07), Labronema (9,59), Dorylaimellus (8,06), Acrobeles $(5,71)$, Discolaimoides (5,66), Eudorylaimus (5,34), Dorylaimoides (4,00), Helicotylenchus $(3,30)$ e Basirotyleptus (3,25); 2) Helicotylenchus (48,32), Acrobeles $(5,85)$, Dorylaimellus (5,66), Eudorylaimus $(5,12)$, Rhabditis $(4,53)$, Mesodorylaimus $(3,24)$, Xiphinema $(3,00)$, Diphtherophora $(2,80)$, Discolaimium $(2,68)$ e Opisthodorylaimus $(1,94) ; 3)$ Helicotylenchus $(30,48)$, Pratylenchus $(20,68)$, Eudorylaimus $(6,07)$, Opisthodorylaimus (6,07), Acrobeles (5,09), Aporcelaimellus $(3,86)$, Mesodorylaimus $(3,12)$, Nygolaimellus $(2,41)$, Chitwoodius $(2,10)$ e Discolaimium $(1,75)$.

Em relação às amostras de raízes da primeira amostragem, as famílias encontradas foram as seguintes: 1) Tylenchidae $(53,49)$, Tylenchulidae $(18,34)$, Aphelenchidae $(9,39)$, Hoplolaimidae $(9,39)$, Pratylenchidae $(5,89)$, Anguinidae $(2,41)$ e Criconematidae (1,09); 2) Hoplolaimidae (57,73); Pratylenchidae $(24,82)$, Tylenchidae $(15,01)$ e Aphelenchidae $(2,41)$; 3) Pratylenchidae $(87,33)$; Hoplolaimidae $(6,73)$; Aphelenchoididae $(3,20)$, Tylenchidae $(2,56)$ e Aphelenchidae $(0,17)$. Os gêneros identificados, nesse mesmo caso, foram os seguintes: 1) Paratylenchus $(14,85)$, Aphelenchus (9,39), Helicotylenchus (9,39), Pratylenchus $(5,90)$, Tylenchulus $(3,49)$, Ditylenchus (2,40) e Discocriconemella (1,09); 2) Helicotylenchus (57,73), Pratylenchus $(24,82)$ e Aphelenchus (2,41); 3) Pratylenchus (87,33), Helicotylenchus (6,73), Aphelenchoides $(3,20)$ e Aphelenchus $(0,17)$.

Em relação às amostras de solo da segunda amostragem (fevereiro de 2000), as dez famílias mais abundantes foram as seguintes: 1) Criconematidae $(31,08)$, Qudsianematidae $(22,64)$, Cephalobidae $(11,84)$, Dorylaimidae $(5,06)$, Leptonchidae $(3,83)$, Rhabditidae $(3,52)$, Aporcelaimidae $(3,33)$, Mydonomidae $(2,96)$, Belondiridae $(2,83)$ e Hoplolaimidae $(2,54)$; 2) Hoplolaimidae $(35,78)$, Longidoridae $(10,99)$, Cephalobidae $(9,66)$, Qudsianematidae $(8,07)$, Diphtherophoridae $(6,02)$, Rhabditidae $(5,60)$, Criconematidae $(4,90)$, Mydonomidae $(3,61)$, Trichodoridae $(3,61)$ e Tylenchidae $(2,22)$; 3) Hoplolaimidae $(32,57)$, Cephalobidae $(15,78)$, Tylencholaimidae $(8,99)$, Tylenchidae $(7,18)$, Trichodoridae $(6,98)$, Dorylaimidae $(6,59)$, Diphtherophoridae $(4,31)$, Rhabditidae $(3,42)$, Anguinidae $(3,00)$ e Aphelenchidae $(2,80)$. Os dez gêneros 
identificados mais abundantes, nesse mesmo caso, foram os seguintes: 1) Discocriconemella $(23,42)$, Acrobeles (8,88), Eudorylaimus (6,09), Labronema $(5,96)$, Mesodorylaimus (5,09), Criconemella $(5,05)$, Discolaimium $(4,14)$, Aporcelaimellus (3,33), Dorylaimoides (2,95) e Hemicriconemoides (2,60); 2) Helicotylenchus (35,45), Xiphinema (10,88), Acrobeles (7,02), Diphtherophora $(5,96)$, Hemicycliophora $(4,78)$, Paratrichororus $(3,58)$, Dorylaimoides $(3,51)$, Rhabditis (2,75), Discolaimium (2,59) e Labronema (1,73); 3) Helicotylenchus $(32,52)$, Chitwoodius $(8,98)$, Paratrichodorus $(6,97)$, Acrobeles $(6,67)$, Diphtherophora $(4,34)$, Mesodorylaimus $(3,32)$, Zeldia $(3,32)$, Eucephalobus $(3,12)$, Opisthodorylaimus $(3,06)$ e Ditylenchus $(2,99)$.

Em relação às amostras de raízes da segunda amostragem, as famílias encontradas foram as seguintes: 1) Tylenchidae $(33,70)$, Tylenchulidae $(19,42)$, Criconematidae (18,53), Pratylenchidae $(13,84)$, Hoplolaimidae $(8,70)$, Aphelenchidae $(3,80)$ e Longidoridae $(2,01)$; 2) Pratylenchidae $(40,13)$, Hoplolaimidae $(37,62)$ e Tylenchidae $\quad(22,24) ; \quad 3)$ Hoplolaimidae $\quad(40,82), \quad$ Pratylenchidae $\quad(35,99)$, Aphelenchoididae $(15,70)$ e Tylenchidae $(7,49)$. Os gêneros identificados, nesse mesmo caso, foram os seguintes: 1) Discocriconemella $(18,53)$, Pratylenchus $(13,84)$, Tylenchulus $(12,28)$, Helicotylenchus $(8,70)$, Paratylenchus $(7,14)$, Aphelenchus $(3,80)$ e Xiphinema (2,01); 2) Pratylenchus (40,13) e Helicotylenchus (37,62); 3) Helicotylenchus $(40,82)$, Pratylenchus $(35,99)$ e Aphelenchoides $(15,70)$.

$\mathrm{Na}$ área de cerrado, a ordem Dorylaimida foi a mais abundante em amostras de solo, tanto na primeira como na segunda amostragem, com $51,84 \%$ e $45,04 \%$ de abundâncias relativas, respectivamente, sendo seguida por Tylenchida e Rhabditida. Na área de goiabal, a ordem Tylenchida foi a mais abundante em amostras de solo, tanto na primeira como na segunda amostragem, com 51,57\% e 43,67\% de abundâncias relativas, respectivamente, sendo seguida por Dorylaimida e Rhabditida. Na área de milharal, a ordem Tylenchida foi a mais abundante em amostras de solo, tanto na primeira como na segunda amostragem, com 58,29\% e 56,26\% de abundâncias relativas, respectivamente, seguida por Dorylaimida e Rhabditida. A subordem Tylenchina apresentou-se como grupo predominante da ordem Tylenchida, em todas as áreas e épocas de amostragem. A 
ordem Dorylaimida foi, portanto, a mais abundante na área de vegetação nativa, enquanto nas áreas cultivadas essa posição foi ocupada por Tylenchida. De fato, nematóides da ordem Dorylaimida podem ser considerados relativamente mais sensíveis a distúrbios ambientais, inclusive devido à implantação da agricultura (Freckman \& Caswell, 1985; Niblack, 1989; Niblack \& Bernard, 1985). Por outro lado, o predomínio de Tylenchida (e da subordem Tylenchina, dentro da ordem) nas áreas cultivadas reflete o aumento de nematóides fitoparasitos. Muitos estresses ambientais, como aqueles relacionados com a agricultura, resultam nesse aumento (Niles \& Freckman, 1998).

As maiores abundâncias relativas de gêneros em solo de cerrado estiveram em torno de $20 \%$ (Discocriconemella), enquanto em solo das áreas cultivadas foram sempre maiores que 30\% (Helicotylenchus, nas duas áreas), atingindo altos valores, até mesmo superiores a $45 \%$, como no caso da área de goiabal na primeira amostragem. Portanto, comparando-se a área de vegetação nativa com as áreas cultivadas, é possível perceber que os resultados expostos, embora estejam baseados em identificações somente até o nível taxonômico de gênero, indicam veracidade da afirmativa de Ferris \& Ferris (1974, p.290) sobre nematóides de solo: "Em áreas naturais, a maioria das espécies são relativamente raras em números relativos, com poucas dominantes".

Alguns nematóides, que estiveram entre os mais abundantes em solo cerrado, tiveram suas abundâncias consideravelmente reduzidas (Dorylaimellus em milharal) ou não foram detectados em áreas cultivadas (Dorylaimoides e Labronema em milharal, Discocriconemella e Tylenchulus nas duas área cultivadas). Certos nematóides podem apresentar sensibilidade a um determinado distúrbio ambiental, definida como redução na abundância, podendo até resultar em não detecção da presença desses nematóides. Devido ao estabelecimento da agricultura em uma área, ocorrem distúrbios ambientais, que podem ser classificados em duas categorias principais: a) distúrbios químicos, que incluem enriquecimento em nutrientes (adubação) e poluição; b) distúrbios fisicos, que incluem o cultivo do solo (Neher, 2001). Portanto, Dorylaimoides e Labronema podem ser considerados sensíveis aos distúrbios ocorridos na área de milharal e Discocriconemella e Tylenchulus sensíveis aos ocorridos nas duas áreas cultivadas. 
Mattos (1999) obteve resultados semelhantes na região do Distrito Federal (Brasil), exceto em relação a Labronema.

O gênero Discocriconemella foi o mais abundante em solo de cerrado, em ambas as amostragens, não sendo detectado nas áreas cultivadas. Elevadas abundâncias desse gênero também foram relatadas por Mattos (1999) em áreas de cerrado na região do Distrito Federal, Brasil. Nematóides da superfamília Criconematoidea, em especial da família Criconematidae (nematóides anelados), estão freqüentemente associados à vegetação nativa, sendo muitas vezes abundantes nesses locais; porém, quando há implantação de cultivos agrícolas, esses nematóides geralmente têm suas abundâncias reduzidas (Yeates, 1991). Cares \& Huang (1991) verificaram que nematóides anelados tiveram suas abundâncias muito reduzidas, algumas vezes até níveis não detectáveis, quando a vegetação natural de cerrado na região do Brasil Central foi substituída por culturas, anuais ou perenes. Na região do Distrito Federal, a superfamília Criconematoidea tem desempenhado um importante papel na distinção entre áreas nativas e cultivadas (Cares \& Huang, 1991; Mattos, 1999). No caso do presente rabalho, essa superfamília apresentou abundâncias relativas elevadas em cerrado, em torno de $30 \%$, enquanto em goiabal e milharal esses valores foram muito inferiores, nunca maiores que $5 \%$, considerando as duas amostragens. Além disso, ocorreu um maior número de gêneros pertencentes a superfamília Criconematoidea encontrados em cerrado, tanto da família Criconematidae (Criconemella, Discocriconemella e Hemicriconemoides), como da família Tylenchulidae (Paratylenchus e Tylenchulus). Nas áreas cultivadas, a superfamília esteve representada apenas pela família Criconematidae: Criconemella nas duas áreas e Hemicycliophora apenas em goiabal. Certas espécies de Criconemella eventualmente podem apresentar maior capacidade de adaptação ao uso agrícola da terra, em relação a outros nematóides anelados. Mattos (1999) observou ocorrência expressiva desse gênero em áreas de vegetação nativa, como também em algumas áreas cultivadas. No presente estudo, as abundâncias de Criconemella nas áreas cultivadas foram bastante baixas, resultado que está em concordância com os obtidos por Cares \& Huang (1991), que relataram reduções nas 
abundâncias de todos os nematóides anelados, inclusive Criconemella, com a retirada da vegetação nativa de cerrado e a implantação de cultivos agrícolas.

$\mathrm{O}$ gênero Helicotylenchus foi o mais abundante em solo das duas áreas cultivadas e nas duas épocas de amostragem. Em cerrado, esse gênero também esteve presente, porém com abundâncias muito inferiores. Foi possível, portanto, diferenciar as áreas cultivadas da área de cerrado com base nas abundâncias relativas do gênero, sendo que o mesmo foi favorecido pelos cultivos implantados. Outros autores obtiveram resultados semelhantes em relação a Helicotylenchus, nas comparações entre cerrado e várias culturas (Mattos, 1999) e entre cerrado e cultura de soja (Cares \& Huang, 1991).

Verificou-se presença do gênero Xiphinema entre os mais abundantes em solo da área de goiabal, porém o mesmo não ocorreu nas outras áreas. Mattos (1999) detectou a presença de Xiphinema em algumas áreas, cultivadas ou não, sempre com baixas abundâncias relativas, exceto no caso de área de eucalipto, em que o gênero foi o mais abundante, sendo favorecido pelo cultivo estabelecido; em área de milho não foi detectada a presença do gênero. Cares \& Huang (1991) observaram redução nas abundâncias de Xiphinema após a retirada da vegetação original de cerrado e implantação de cultivo de soja ou arroz.

Em todas as áreas amostradas, os nematóides fitoparasitos presentes foram ectoparasitos, exceto no caso de Pratylenchus, endoparasito migrador. Exemplares de Pratylenchus estiveram presentes em raízes, em todas as áreas e épocas de amostragem, atingindo em alguns casos abundâncias bastante elevadas. Porém, em amostras de solo, esses nematóides tiveram presença detectada somente em milharal na primeira amostragem, época em que as plantas de milho encontravam-se em fase final de ciclo (fase de maturação fisiológica ou ponto de silagem). Pode-se afirmar que um nematóide do gênero Pratylenchus, devido ao endoparasitismo, normalmente desenvolve-se durante a maior parte do seu tempo de vida no interior de tecidos radiculares. Após a penetração no sistema radicular e estabelecimento do parasitismo, o nematóide pode retornar ao solo, em geral nas seguintes situações (que podem ocorrer simultaneamente ou não): quando as populações de nematóides nas raízes tornam-se muito altas, ocasionando sério depauperamento da planta; quando a planta entra em senescência ou 
em fases finais do ciclo (Agrios, 1997; Ferraz \& Monteiro, 1995). Dessa maneira, o conhecimento do ciclo de vida de Pratylenchus auxilia a compreensão dos resultados obtidos. Na primeira amostragem em milharal, único caso em que Pratylenchus foi observado em solo, as populações de Pratylenchus em raízes estavam muita altas (média de 1007,8 nematóides por $5 \mathrm{~g}$ de raízes, $87,33 \%$ de abundância relativa) e as plantas de milho encontravam-se em fase final do ciclo. Torna-se necessário, portanto, considerar juntamente as abundâncias em raízes e em solo. Assim, é possível afirmar que, em amostras de solo+raízes, o gênero Pratylenchus foi abundante em todas as áreas cultivadas e épocas de amostragem, apresentando elevação de abundâncias nas áreas cultivadas, em relação à área de cerrado (Tabelas 9 e 10). Mattos (1999) encontrou Pratylenchus somente em áreas cultivadas e Cares \& Huang (1991) o encontraram tanto em áreas de vegetação nativa como cultivada, sendo que esses trabalhos foram realizados na região do Brasil Central, utilizando apenas amostras de solo. Evidencia-se pelos resultados obtidos no presente trabalho a necessidade de considerar as amostras de raízes juntamente com as de solo em estudos de diversidade de nematóides.

Além da família Criconematidae e superfamília Criconematoidea, os seguintes gêneros permitiram realizar distinção entre as áreas cultivadas e a área de cerrado, com base em comparações de médias das abundâncias absolutas em amostras de solo+raízes: Dorylaimellus, Helicotylenchus e Pratylenchus (Tabelas 9 e 10). A superfamília Criconematoidea e família Criconematidae apresentaram maiores abundâncias em cerrado. Os gêneros Helicotylenchus e Pratylenchus, por outro lado, apresentaram maiores abundâncias nas áreas cultivadas. $\mathrm{O}$ gênero Dorylaimellus possibilitou distinguir a área de milharal da área de cerrado, com menores abundâncias em milharal. Portanto, de acordo com o conceito de sensibilidade a um distúrbio (Neher, 2001), mostraram-se sensíveis aos distúrbios devido à implantação de um ou dois dos cultivos, nematóides dos seguinte toxa: superfamília Criconematoidea e família Criconematidae (em relação aos dois cultivos); Dorylaimellus (em relação ao cultivo de milho). Além disso, Helicotylenchus e Pratylenchus foram favorecidos (Yeates, 1991) pelo estabelecimento dos dois cultivos. 
Tabela 9. Abundâncias absolutas de taxa de nematóides que possibilitaram distinção entre as áreas de cerrado, goiabal e milharal em São Carlos, SP (amostragem em maio de 1999; médias de 10 amostras de solo+raízes). ${ }^{1}$

\begin{tabular}{llll}
\hline & Cerrado & Goiabal & Milharal \\
\hline Criconematoidea & $118,20 \mathrm{a}$ & $2,50 \mathrm{~b}$ & $1,00 \mathrm{~b}$ \\
Criconematidae & $69,50 \mathrm{a}$ & $2,50 \mathrm{~b}$ & $1,00 \mathrm{~b}$ \\
Dorylaimellus & $32,00 \mathrm{a}$ & $37,40 \mathrm{a}$ & $2,30 \mathrm{~b}$ \\
Helicotylenchus & $17,40 \mathrm{~b}$ & $359,70 \mathrm{a}$ & $624,90 \mathrm{a}$ \\
Pratylenchus & $2,70 \mathrm{c}$ & $17,50 \mathrm{~b}$ & $1379,10 \mathrm{a}$ \\
\hline
\end{tabular}

1- Letras distintas (para cada taxon) indicam diferenças significativas pelo teste de Duncan a $5 \%$, com dados transformados para $\log (x+1)$.

Tabela 10. Abundâncias absolutas de toxxa de nematóides que possibilitaram distinção entre as áreas de cerrado, goiabal e milharal em São Carlos, SP (amostragem em fevereiro de 2000; médias de 10 amostras de solo+raízes). ${ }^{1}$

\begin{tabular}{llll}
\hline & Cerrado & Goiabal & Milharal \\
\hline Criconematoidea & $118,00 \mathrm{a}$ & $21,00 \mathrm{~b}$ & 0,00 \\
Criconematidae & $107,30 \mathrm{a}$ & $21,00 \mathrm{~b}$ & 0,00 \\
Dorylaimellus & $7,10 \mathrm{a}$ & $5,80 \mathrm{ab}$ & $0,30 \mathrm{~b}$ \\
Helicotylenchus & $11,40 \mathrm{~b}$ & $175,90 \mathrm{a}$ & $149,60 \mathrm{a}$ \\
Pratylenchus & $6,20 \mathrm{~b}$ & $24,00 \mathrm{a}$ & $44,70 \mathrm{a}$
\end{tabular}

1- Letras distintas (para cada toxon) indicam diferenças significativas pelo teste de Duncan a $5 \%$, com dados transformados para $\log (x+1)$.

Alguns gêneros foram muito freqüentes em amostras de solo nas áreas cultivadas, com ocorrência em 90 ou $100 \%$ das amostras coletadas, considerando tanto a primeira como a segunda amostragem: Helicotylenchus em goiabal e milharal e Acrobeles somente em goiabal. Na área de cerrado, os gêneros mais freqüentes em amostras de solo na primeira amostragem (Discocriconemella e Dorylaimellus, ambos com $90 \%$ de freqüência absoluta) foram diferentes daqueles mais freqüêntes na segunda 
amostragem (Acrobeles, Aporcelaimellus, Eudorylaimus e Labronema, todos com 90 ou $100 \%$ de freqüência absoluta).

Em geral, as famílias e gêneros com as maiores abundâncias apresentaram também maiores freqüências e valores de proeminência, com algumas exceções. Em amostras de solo, algumas famílias que não figuraram entre as dez mais abundantes estiveram posicionadas entre as dez mais freqüentes, como, na primeira amostragem, foi o caso de Diphtherophoridae em cerrado e, na segunda amostragem, Alaimidae em cerrado, e Aphelenchoididae e Qudsianematidae em milharal. Ainda em relação às amostras de solo, o mesmo ocorreu para alguns gêneros identificados, como, na primeira amostragem, com Diphtherophora em cerrado, Mylonchulus em goiabal e Plectus em milharal e, na segunda amostragem, Alaimus e Dicolaimoides em cerrado, Opisthodorylaimus em goiabal e Eudorylaimus em milharal. Apenas uma família e dois gêneros que não foram colocados entre os grupos mais abundantes estiveram entre aqueles com os maiores valores de proeminência, na segunda amostragem de solo de cerrado (Alaimidae e Alaimus) e milharal (Aphelenchus). Esses dados mostram que, em certos casos, nematóides pouco abundantes podem ser relativamente freqüentes em amostras de solo. Muitos nematóides podem sobreviver no solo em baixos níveis populacionais, às vezes não detectáveis (Dropkin, 1980; Norton, 1978, Wallace, 1973). Medidas de diversidade que conferem maior peso a grupos taxonômicos pouco abundantes (como o índice de Shannon-Weaver) são adequadas para utilização em estudos de comunidades de nematóides do solo (Freckman \& Ettema, 1993).

\section{4 Índices de similaridade}

Os índices de similaridade entre áreas, para comparações de fauna nematológica, estão apresentados nas Tabelas 11 e 12 (indices de Jaccard) e 13 a 16 (índices de Bray \& Curtis). Ambos os índices são medidas de menor ou maior semelhança entre duas áreas ou coberturas vegetais, em relação às comunidades de nematóides, podendo apresentar valores que variam de 0 a 1 .

Os índices de Jaccard, cujo cálculo é baseado apenas na presença ou ausência de taxa (Norton, 1978), mostraram maior similaridade entre áreas em geral quando 
foram comparadas as comunidades de nematóides considerando o nível taxonômico de família (Tabela 11), pois esses índices variaram de 0,69 a 0,79. Quando foram comparadas comunidades de nematóides considerando o nível taxonômico de gênero (Tabela 12), houve menor similaridade entre áreas em geral, pois os índices variaram de 0,50 a 0,59. Esses resultados indicam, como era esperado, maior sensibilidade do índice para detectar diferenças quando as comparações foram feitas com base em gêneros.

Os índices de Jaccard, tanto com base em famílias como em gêneros, indicaram a seguinte ordem decrescente de similaridade dos pares de áreas: goiabal e milharal; cerrado e goiabal; cerrado e milharal. Ou seja, as áreas cultivadas foram as mais similares entre si e, em seguida, a área de cerrado foi mais similar à área de cultura perene (goiabeira) e menos similar à área de cultura anual (milho). Esses resultados sugerem que houve uma menor intensidade de intervenção humana $e$, conseqüentemente, menor alteração nas comunidades de nematóides na área de cultura perene (em relação a área de cultura anual), em concordância com trabalhos já realizados sobre o assunto (Cares \& Huang, 1991; Mattos, 1999).

Tabela 11. Índices de similaridade de Jaccard para comparações de fauna nematológica entre áreas em São Carlos, SP, com base em famílias ocorrentes em amostras de solo e raízes (amostragens realizadas em maio de 1999 e fevereiro de 2000).

\begin{tabular}{lcc}
\hline & Cerrado & Goiabal \\
\hline Cerrado & - & \\
Milharal & 0,69 & 0,79 \\
Goiabal & 0,71 & - \\
\hline
\end{tabular}


Tabela 12. Índices de similaridade de Jaccard para comparações de fauna nematológica entre áreas em São Carlos, SP, com base em gêneros identificados em amostras de solo e raízes (amostragens realizadas em maio de 1999 e fevereiro de 2000).

\begin{tabular}{lcc}
\hline & Cerrado & Goiabal \\
\hline Cerrado & - & \\
Milharal & 0,50 & 0,59 \\
Goiabal & 0,54 & - \\
\hline
\end{tabular}

Para o cálculo dos índices de Bray \& Curtis são consideradas, além das presenças e ausências, as abundâncias de taxa (Bray \& Curtis, 1957) e, por esse motivo, os resultados estão apresentados separadamente para cada época de amostragem (Tabelas 13 a 16). Da mesma maneira, como foi observado em relação aos índices de Jaccard, os resultados referentes aos índices de Bray \& Curtis indicaram, como esperado, maior sensibilidade em detectar diferenças entre comunidades de nematóides quando foi considerado o nível taxonômico de gênero.

A ordem decrescente de similaridade dos pares de áreas foi a mesma que a obtida para o índice de Jaccard, exceto no caso dos índices calculados com base em famílias para a primeira amostragem, em que se observou maior similaridade entre cerrado e goiabal do que entre as duas áreas cultivadas. Considerando que o cálculo dos índices com base em gêneros apresentou maior sensibilidade em detectar diferenças, índices com base em famílias podem não representar adequadamente as situações reais encontradas no campo. De forma geral, os resultados estão em concordância com trabalhos já realizados (Cares \& Huang, 1991; Mattos, 1999). 
Tabela 13. Índices de similaridade de Bray \& Curtis para comparações de fauna nematológica entre áreas em São Carlos, SP, com base em famílias ocorrentes em amostras de solo (amostragem realizada em maio de 1999).

\begin{tabular}{lcc}
\hline & Cerrado & Goiabal \\
\hline Cerrado & - & \\
Milharal & 0,19 & 0,23 \\
Goiabal & 0,37 & - \\
\hline
\end{tabular}

Tabela 14. Índices de similaridade de Bray \& Curtis para comparações de fauna nematológica entre áreas em São Carlos, SP, com base em gêneros identificados em amostras de solo (amostragem realizada em maio de 1999).

\begin{tabular}{lcc}
\hline & Cerrado & Goiabal \\
\hline Cerrado & - & \\
Milharal & 0,12 & 0,47 \\
Goiabal & 0,28 & - \\
\hline
\end{tabular}

Tabela 15. Índices de similaridade de Bray \& Curtis para comparações de fauna nematológica entre áreas em São Carlos, SP, com base em famílias ocorrentes em amostras de solo (amostragem realizada em fevereiro de 2000).

\begin{tabular}{lcc}
\hline & Cerrado & Goiabal \\
\hline Cerrado & - & \\
Milharal & 0,29 & 0,57 \\
Goiabal & 0,42 & - \\
\hline
\end{tabular}


Tabela 16. Índices de similaridade de Bray \& Curtis para comparações de fauna nematológica entre áreas em São Carlos, SP, com base em gêneros identificados em amostras de solo (amostragem realizada em fevereiro de 2000).

Cerrado Goiabal

\begin{tabular}{lcc}
\hline Cerrado & - & \\
Milharal & 0,19 & 0,52 \\
Goiabal & 0,30 & -
\end{tabular}

\subsection{Medidas de diversidade}

\subsubsection{Números de taxa encontrados em relação ao número de amostras coletadas}

Os gráficos representativos dos números acumulados de famílias ou gêneros de nematóides encontrados (riqueza acumulada) em relação ao número de amostras coletadas, considerando as duas épocas de amostragem, estão apresentados nas Figuras 5 a 8. Pelo exame dos gráficos apresentados, pode-se concluir que o número de amostras foi suficiente, para todas as áreas estudadas, com pequenos aumentos do número de toxa encontrados com utilização de mais de dez amostras. 


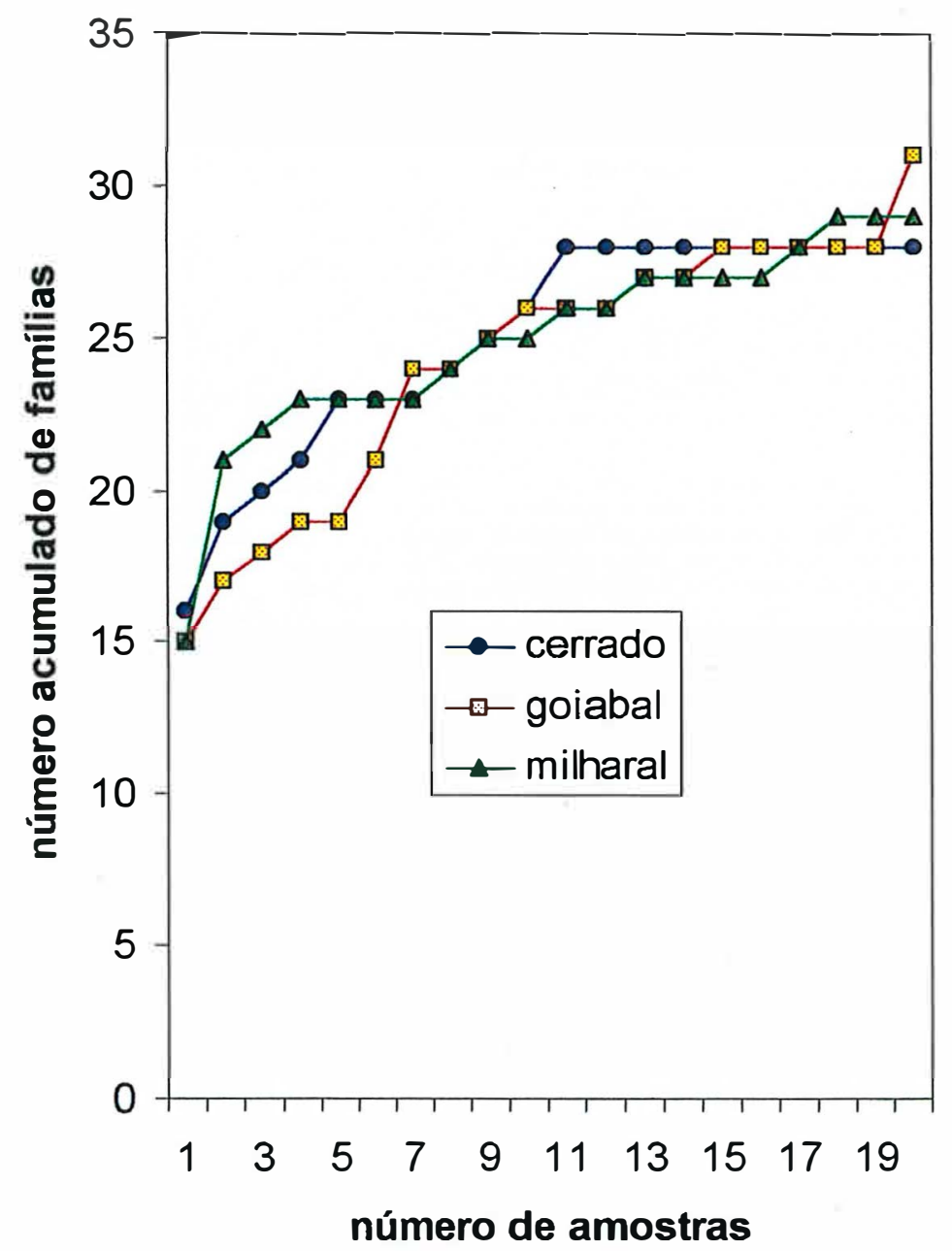

Figura 5 - Números acumulados de famílias de nematóides em relação ao número de amostras de solo coletadas em áreas de cerrado, goiabal e milharal em São Carlos, SP (amostragens realizadas em maio de 1999 e fevereiro de 2000). 


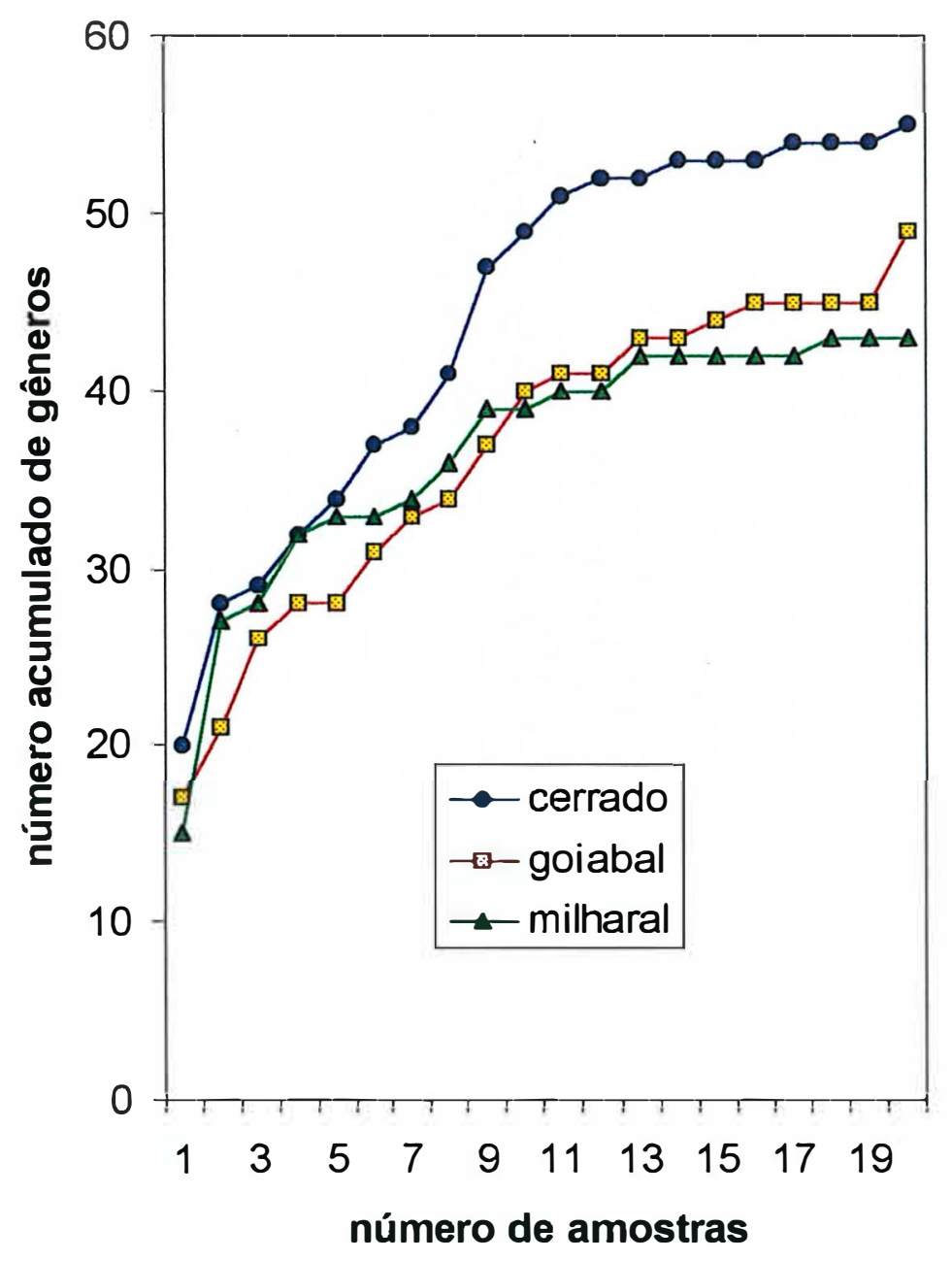

Figura 6 - Números acumulados de gêneros de nematóides em relação ao número de amostras de solo coletadas em áreas de cerrado, goiabal e milharal em São Carlos, SP (amostragens realizadas em maio de 1999 e fevereiro de 2000). 


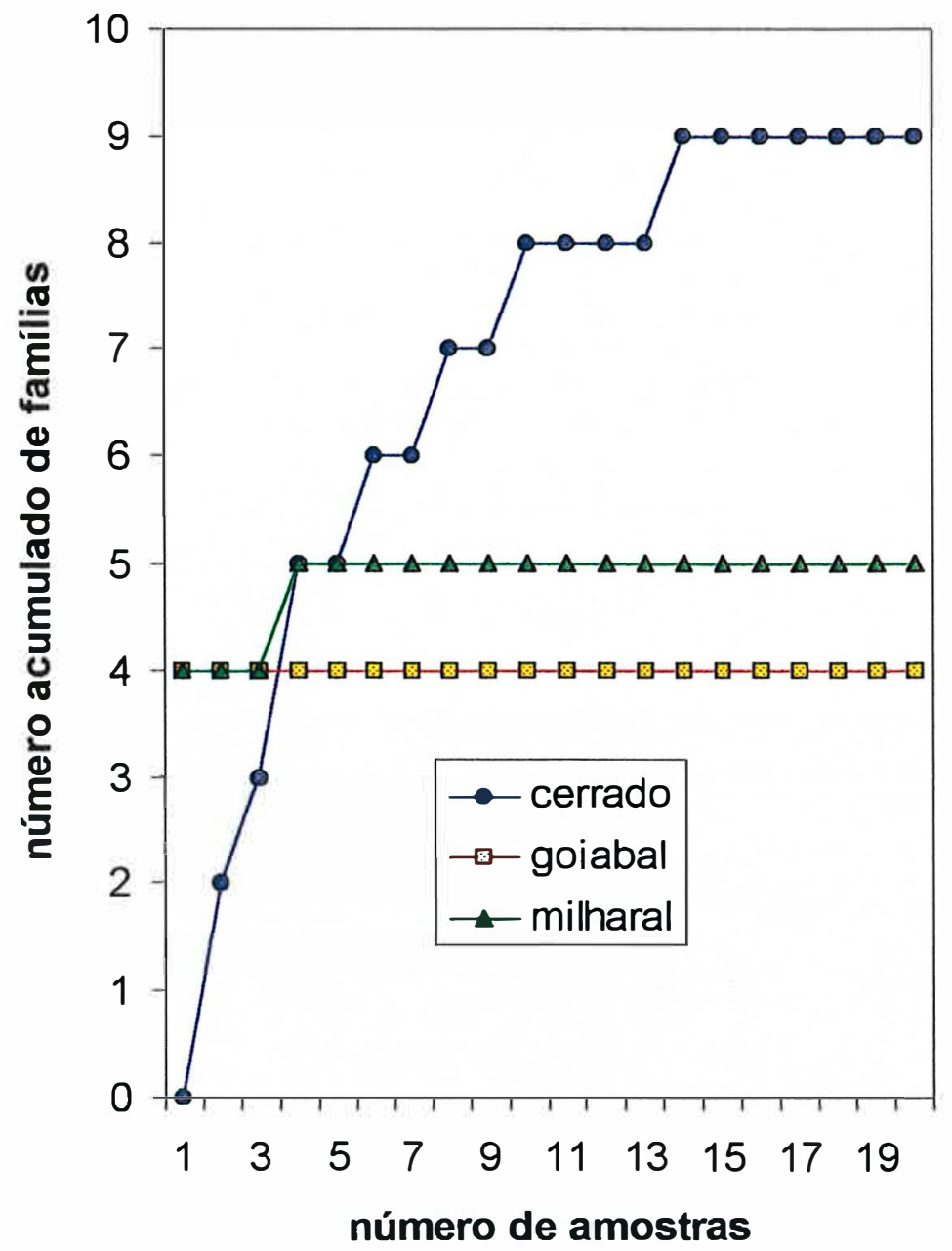

Figura 7 - Números acumulados de famílias de nematóides em relação ao número de amostras de raízes coletadas em áreas de cerrado, goiabal e milharal em São Carlos, SP (amostragens realizadas em maio de 1999 e fevereiro de 2000). 


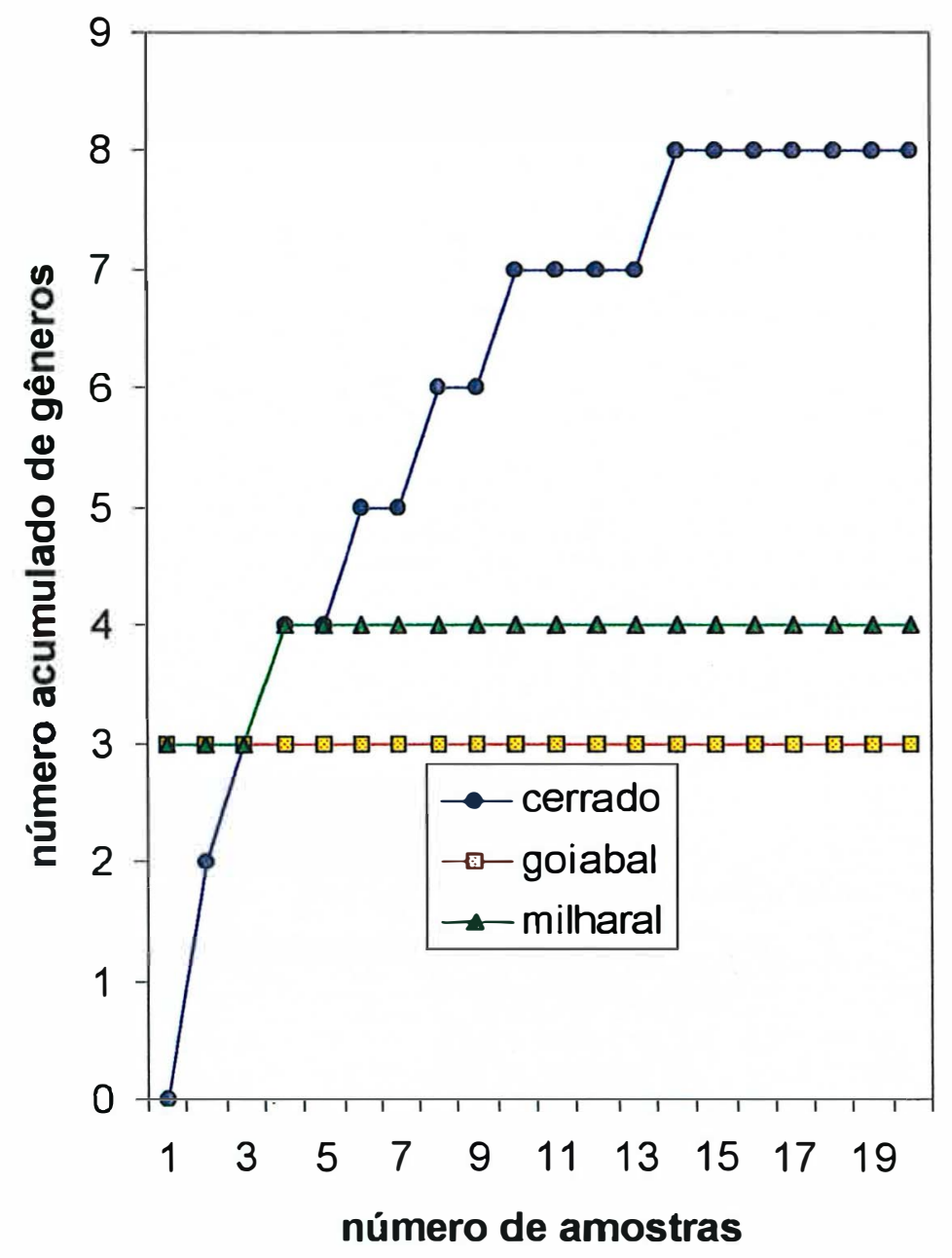

Figura 8 - Números acumulados de gêneros de nematóides em relação ao número de amostras de raízes coletadas em áreas de cerrado, goiabal e milharal em São Carlos, SP (amostragens realizadas em maio de 1999 e fevereiro de 2000). 


\subsubsection{Riqueza}

As riquezas (ou números) de famílias ou gêneros de nematóides encontrados em amostras de solo ou raízes estão apresentadas nas Tabelas 17 a 20 . Em relação às amostras de solo, foi possível distingüir a área de cerrado, com maior riqueza, das áreas cultivadas, apenas com base em gêneros de nematóides. Em relação às amostras de raízes, essa distinção foi possível com base em famílias e gêneros. Esses resultados estão de acordo com aqueles obtidos na maior parte dos trabalhos realizados sobre o assunto, no Brasil e no exterior, que mostram a ocorrência de um maior número de taxa de nematóides em áreas de vegetação nativa, em relação às áreas cultivadas (Freckman \& Ettema, 1993; Hánel, 1995; Mattos, 1999; Zamith \& Lordello, 1957; Yeates \& King, 1997). Por outro lado, Bloemers et al. (1997) observaram que atividades agrícolas tiveram pouco efeito na riqueza de taxa de nematóides e Valocká et al. (2001) obtiveram maiores riquezas em culturas de cereais, em relação a pastagens nativas.

Tabela 17. Riquezas (ou números) de famílias de nematóides presentes em amostras de solo coletadas em áreas de cerrado, goiabal e milharal em São Carlos, SP (amostragens em maio de 1999 e fevereiro de 2000).

\begin{tabular}{lccc}
\hline Áreas & Maio/1999 & Fevereiro/2000 & Riqueza total * \\
\hline Cerrado & 26 & 24 & 28 \\
Goiabal & 26 & 27 & 31 \\
Milharal & 25 & 25 & 29 \\
\hline
\end{tabular}

* Números de famílias diferentes que ocorreram nas amostras de solo, considerando as duas épocas de amostragem. 
Tabela 18. Riquezas (ou números) de gêneros de nematóides identificados em amostras de solo coletadas em áreas de cerrado, goiabal e milharal em São Carlos, SP (amostragens em maio de 1999 e fevereiro de 2000).

\begin{tabular}{lccc}
\hline Áreas & Maio/1999 & Fevereiro/2000 & Riqueza total * \\
\hline Cerrado & 49 & 46 & 55 \\
Goiabal & 40 & 37 & 49 \\
Milharal & 39 & 35 & 43
\end{tabular}

* Números de gêneros diferentes que ocorreram nas amostras de solo, considerando as duas épocas de amostragem.

Tabela 19. Riquezas (ou números) de famílias de nematóides presentes em amostras de raízes coletadas em áreas de cerrado, goiabal e milharal em São Carlos, SP (amostragens em maio de 1999 e fevereiro de 2000).

\begin{tabular}{lccc}
\hline Áreas & Maio/1999 & Fevereiro/2000 & Riqueza total * \\
\hline Cerrado & 7 & 8 & 9 \\
Goiabal & 4 & 3 & 4 \\
Milharal & 5 & 4 & 5
\end{tabular}

* Números de famílias diferentes que ocorreram nas amostras de raízes, considerando as duas épocas de amostragem.

Tabela 20. Riquezas (ou números) de gêneros de nematóides identificados em amostras de raízes coletadas em áreas de cerrado, goiabal e milharal em São Carlos, SP (amostragens em maio de 1999 e fevereiro de 2000).

\begin{tabular}{lccc}
\hline Áreas & Maio/1999 & Fevereiro/2000 & Riqueza total ${ }^{*}$ \\
\hline Cerrado & 7 & 7 & 8 \\
Goiabal & 3 & 2 & 3 \\
Milharal & 4 & 3 & 4
\end{tabular}

* Números de gêneros diferentes que ocorreram nas amostras de raízes, considerando as duas épocas de amostragem. 


\subsection{3 Índice de Shannon-Weaver}

Os índices de diversidade de Shannon-Weaver ( $\left.\mathrm{H}^{\prime}\right)$ estão apresentados na Tabela 21. Apesar de pequenas diferenças, os índices foram maiores em cerrado do que em áreas cultivadas, exceto no caso da primeira amostragem (maio de 1999), cujos índices para cerrado e milharal apresentaram valores iguais $(0,84)$ e maiores que o índice para goiabal $(0,74)$. Provavelmente diferenças mais claras poderiam ser obtidas caso todos os nematóides tivessem sido identificados até nível de gênero e os índices fossem calculados com base nesse taxon. Os resultados em geral estão de acordo com os obtidos em estudos já realizados sobre o tema (Freckman \& Ettema, 1993; Hánel, 1995; Mattos, 1999; Yeates \& King, 1997). Por outro lado, não foi possível realizar diferenciação consistente entre as duas áreas cutivadas com base no índice de Shannon-Weaver, provavelmente porque o mesmo foi obtido levando em consideração as identificações realizadas somente até nível de família.

Tabela 21. Índices de diversidade de Shannon-Weaver $\left(H^{\prime}\right)$ das comunidades de nematóides no solo das áreas de amostragem em São Carlos, SP (calculado com base na diversidade de famílias de nematóides; médias de 10 amostras de solo para cada área e época de amostragem).

\begin{tabular}{lccc}
\hline Areas & Maio/1999 & Fevereiro/2000 & Média geral $^{*}$ \\
\hline Cerrado & 0,84 & 0,85 & 0,85 \\
Goiabal & 0,74 & 0,81 & 0,78 \\
Milharal & 0,84 & 0,82 & 0,83 \\
\hline
\end{tabular}

* H' calculado considerando as duas épocas de amostragem (total de 20 amostras para cada área).

\subsection{4 Índice de equiitabilidade}

Os índices de eqüitabilidade ( $\mathrm{J}^{\prime}$ ) obtidos, que medem a uniformidade de diferentes toxa em relação a suas abundâncias relativas, estão apresentados na Tabela 22. Apesar de pequenas diferenças, os maiores valores ocorreram em relação a cerrado, exceto na segunda amostragem (fevereiro de 2000), cujos índices de cerrado e goiabal foram iguais $(0,77)$ e maiores em relação a milharal $(0,68)$. $\mathrm{O}$ mesmo comentário feito 
em relação ao índice de Shannon-Weaver também é válido: provavelmente diferenças mais claras pudessem ser obtidas caso todos os nematóides tivessem sido identificados até nível de gênero e os índices fossem calculados com base nesse taxxon. Ainda não foram realizados outros estudos semelhantes em que se utiliza o índice de eqüitabilidade para comparação entre comunidades de nematóides em áreas de vegetação nativa e cultivada.

Tabela 22. Índices de eqüitabilidade ( $\left.\mathrm{J}^{\prime}\right)$ das comunidades de nematóides no solo das áreas de amostragem em São Carlos, SP (calculado com base na diversidade de famílias de nematóides; média de 10 amostras de solo para cada área e época de amostragem).

\begin{tabular}{lccc}
\hline Áreas & Maio/1999 & Fevereiro/2000 & Média geral * \\
\hline Cerrado & 0,81 & 0,77 & 0,79 \\
Goiabal & 0,69 & 0,77 & 0,73 \\
Milharal & 0,71 & 0,68 & 0,69 \\
\hline
\end{tabular}

* J' calculado considerando as duas épocas de amostragem (total de 20 amostras para cada área) .

\subsection{Hábitos alimentares}

Os índices de diversidade trófica (T) estão apresentados na Tabela 23. Os resultados mostraram maior diversidade trófica, ou seja, diversidade de hábitos alimentares, na comunidade de nematóides em vegetação nativa (cerrado), em relação às comunidades das áreas cultivadas. Considerando apenas as comunidades de nematóides das áreas cultivadas, maior diversidade trófica foi observada em milharal.

A superioridade dos índices de diversidade trófica em cerrado pode ser explicada pelas características que em geral apresentam áreas de vegetação nativa, que são, principalmente, maior diversidade em relação a espécies de plantas e ambiente, maior quantidade de matéria orgânica no solo (Tabela 3, Material e Métodos), menores níveis de intervenção humana e mudanças ambientais. Nessas condições, as comunidades de nematóides no solo em geral apresentam-se maduras (clímax) ou encontram-se em fases mais avançadas da sucessão ecológica, o que significa, entre outros aspectos, que diferentes grupos tróficos são favorecidos (Niles \& Freckman, 1998). A diversidade 
trófica, como a diversidade taxonômica, também pode ser considerada uma medida da diversidade biológica na comunidade; portanto, a maior diversidade de nematóides que se espera encontrar em ecossistemas naturais também se aplica aos grupos tróficos e não somente taxonômicos (Freckman \& Ettema, 1993).

Para a superioridade dos índices de diversidade trófica em milharal, com referência à área de goiabal, uma possível explicação estaria relacionada aos manejos diferentes adotados nessas duas áreas, principalmente irrigação, que foi utilizada na área de milharal. Altas correlações positivas já foram verificadas entre precipitação pluviométrica e abundâncias de nematóides de diferentes grupos tróficos, sugerindo que maior umidade do solo, dentro de determinados limites, favorece nematóides dos mais variados hábitos alimentares e, portanto, geralmente resulta em maior diversidade trófica (McSorley, 1997).

Em outros estudos semelhantes, em que foi utilizado o índice de diversidade trófica, os autores afirmaram que esse índice não foi eficiente em distinguir as áreas estudadas (Freckman \& Ettema, 1993; Mattos, 1999).

Tabela 23. Índices de diversidade trófica (T) das comunidades de nematóides nas áreas de amostragem em São Carlos, SP (médias de 10 amostras de solo para cada época de amostragem).

\begin{tabular}{lccc}
\hline Áreas & Maio/1999 & Fevereiro/2000 & Média geral * \\
\hline Cerrado & 3,77 & 3,96 & 3,87 \\
Goiabal & 2,44 & 2,94 & 2,69 \\
Milharal & 3,15 & 3,21 & 3,18 \\
\hline
\end{tabular}

* T calculado considerando as duas épocas de amostragem (total de 20 amostras para cada área).

Estão apresentadas na Figura 9 as abundâncias relativas (\%) de nematóides de cada um dos hábitos alimentares considerados (fitoparasito, bacteriófago, micófago, predador e onívoro), para as três áreas estudadas e duas épocas de amostragem. Houve maior abundância relativa de nematóides predadores ou onívoros na área de cerrado, em relação às áreas cultivadas, com diferenças estatisticamente significativas nas duas 
amostragens realizadas. Nematóides predadores ou onívoros, por ocuparem níveis superiores nas cadeias alimentares do solo, têm sido associados a comunidades maduras (clímax) e considerados relativamente mais sensíveis a mudanças ambientais, inclusive devido à implantação de cultivos agrícolas (Niles \& Freckman, 1998; Wasilewska, 1997; Yeates \& Bongers, 1999).

As abundâncias relativas de nematóides predadores foram superiores em cerrado, em relação às áreas cultivadas, nas duas épocas consideradas, porém com diferença estatisticamente significativa apenas entre cerrado e milharal na segunda amostragem. No caso de nematóides onívoros, as abundâncias relativas foram superiores em cerrado, em relação às áreas cultivadas, nas duas épocas consideradas, com diferenças estatisticamente significativas, exceto no caso da comparação entre cerrado e milharal na segunda amostragem. Mattos (1999), em trabalho realizado na região do Distrito Federal, Brasil, obteve maiores abundâncias relativas de nematóides onívoros em áreas de vegetação nativa de cerrado, em relação a áreas cultivadas; porém, no caso de abundâncias relativas de nematóides predadores, diferenças entre vegetação nativa e cultivada não foram estatisticamente significativas.

Em relação aos nematóides fitoparasitos, as abundâncias relativas foram sempre inferiores em cerrado, em relação às áreas cultivadas, porém com diferenças estatisticamente significativas somente na primeira amostragem. Muitos estresses ambientais resultam em aumento na abundância de nematóides fitoparasitos (Niles \& Freckman, 1998). Monoculturas em geral tendem a favorecer determinados grupos de nematóides fitoparasitos, os quais se tornam mais abundantes com a transformação de ecossistema natural para agroecossistema (Ferris \& Ferris, 1974; Wasilewska, 1997; Yeates, 1999). Contudo, Mattos (1999) não obteve diferenças significativas nas abundâncias relativas de nematóides fitoparasitos entre áreas de vegetação nativa e a uma área de cultura de milho e, quando foram comparadas as áreas de vegetação nativa com áreas de culturas de café, eucalipto e tomate, as abundâncias de nematóides fitoparasitos foram superiores em vegetação nativa, com diferenças estatisticamente significativas. Outros estudos realizados no exterior obtiveram maiores abundâncias de nematóides fitoparasitos em vegetação nativa, em relação a áreas cultivadas (Valocká et 
al., 2001; Yeates \& King, 1997). Hánel (1995), em trabalho realizado na República Tcheca, obteve maior abundância de nematóides fitoparasitos em área de cultura de batata, em relação a uma área de floresta, mas não em relação a uma área de campina natural.

A respeito dos nematóides microbiófagos (bacteriófagos+micófagos), não houve diferenças significativas entre as abundâncias relativas na primeira amostragem. Por outro lado, na segunda amostragem, nematóides micófagos e microbiófagos em geral (bacteriófagos+micófagos) apresentaram maiores abundâncias em milharal, com diferenças estatisticamente significativas, em relação às outras áreas. Nematóides microbiófagos têm sido apontados como aqueles que em geral apresentam maiores variações sazonais em suas abundâncias relativas (Ferris \& Ferris, 1974; Wasilewska, 1997). Esses nematóides ocupam níveis inferiores em cadeias alimentares no solo, podendo ter suas abundâncias elevadas em certas condições de distúrbio ambiental, inclusive devido a atividades agrícolas (Niles \& Freckman, 1998; Wasilewska, 1997).

A abundância maior de nematóides microbiófagos (bacteriófagos+micófagos), estatisticamente significativa, obtida para a área de milharal na segunda amostragem, deveu-se, na realidade, à participação dos micófagos. Quando foi realizada a segunda amostragem, as plantas de milho encontravam-se em crescimento vegetativo, fase na qual são realizadas adubações de cobertura. $\mathrm{Na}$ primeira amostragem, as plantas encontravam-se em final de ciclo (fase de maturação fisiológica ou ponto de silagem). Segundo Wasilewska (1997), um aumento ocasional na abundância de nematóides micófagos pode ocorrer devido a maior acidez do solo em conseqüência do uso de fertilizantes minerais. 

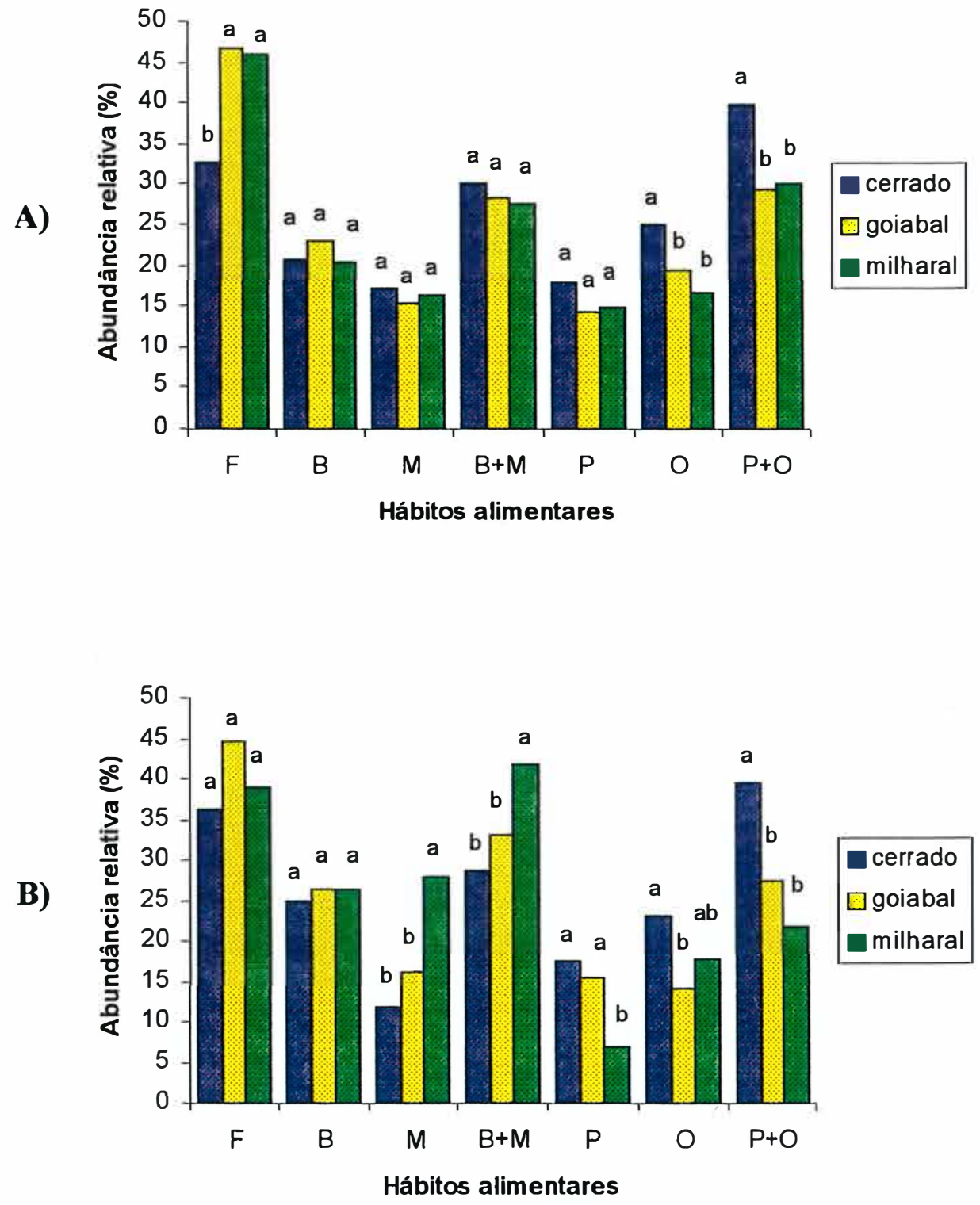

Figura 9 - Abundâncias relativas (\%) de nematóides dos hábitos alimentares fitoparasito $(\mathrm{F})$, bacteriófago $(\mathrm{B})$, micófago $(\mathrm{M})$, bacteriófago ou micófago $(\mathrm{B}+\mathrm{M})$, predador $(\mathrm{P})$, onívoro $(\mathrm{O})$, predador ou onívoro $(\mathrm{P}+\mathrm{O})$, nas áreas de amostragem em São Carlos, SP (médias de 10 amostras de solo para cada área). Letras distintas (em cada hábito alimentar) indicam diferenças significativas pelo teste de Duncan a 5\%, com dados transformados para arco seno da raiz quadrada de $\mathrm{x} / 100$. A) amostragem em maio de 1999; B) amostragem em fevereiro de 2000. 


\section{7 Índices de maturidade}

Na Tabela 24, estão apresentados os valores dos índices de maturidade modificados (Yeates, 1994), índices de maturidade (Bongers, 1990) e índices de parasitos de plantas (Bongers, 1990). Índices mais próximos de 1 estão relacionados com predominância de nematóides "estrategistas-r" ou "colonizadores", característicos de ambientes modificados. Índices mais próximos de 5 estão relacionados com nematóides "estrategistas-k" ou "persistentes", característicos de ambientes estáveis. Esses índices podem variar de 1 a 5 e apresentaram pequenas diferenças entre as áreas estudadas, ficando em geral em torno de 3. Os índices para a área de cerrado foram maiores em relação às áreas cultivadas, nas duas épocas de amostragem, exceto no caso do índice de maturidade (IM) na primeira amostragem: esse índice foi maior para milharal do que para cerrado, embora com pequena diferença $(3,46$ e 3,40, respectivamente), ficando a área de goiabal com o menor índice $(3,24)$. Considerando apenas as áreas cultivadas, não se observou superioridade constante nas duas épocas de amostragem, em relação a qualquer uma das duas áreas. Em vista dos resultados, não foi possível revelar clara predominância de nematóides colonizadores ou persistentes nas áreas estudadas. Mattos (1999), comparando áreas de vegetação nativa e cultivada no Brasil Central, também não encontrou diferenças substanciais entre os índices de maturidade entre áreas de vegetação nativa e cultivada, exceto para uma área cultivada com tomate, a qual se diferenciou das demais pelos menores índices de maturidade. Bloemers et al. (1997) avaliaram o efeito de mudanças ambientais, inclusive devido ao estabelecimento de agricultura, em uma floresta na República dos Camarões, África. Os autores não observaram reduções nos índices de maturidade com crescentes modificações, o que julgaram surpreendente, e comentaram que há necessidade de maior número de pesquisas para que esses índices possam ser melhor utilizados e interpretados em condições de solos ropicais, uma vez que foram desenvolvidos para condições de clima temperado. Nos outros trabalhos em que foram utilizados índices de maturidade, realizados em condições de clima temperado ou subtropical, não ocorreram diferenças consistentes entre áreas de vegetação nativa e cultivada (Freckman \& Ettema, 1993; 
Hánel, 1995) ou índices maiores foram observados em vegetação nativa, em relação a áreas cultivadas (Valocká et al, 2001; Yeates \& King, 1997).

Tabela 24. Índices de maturidade modificados (IMm), índices de maturidade (IM) e índices de parasitos de plantas (IPP) para as áreas de estudo da fauna nematológica em São Carlos, SP (amostragens realizadas em 1999 e 2000; médias de 10 amostras para cada área e época de amostragem).

\begin{tabular}{lccccccccc}
\hline & \multicolumn{3}{c}{ IMm } & \multicolumn{3}{c}{ IM } & \multicolumn{3}{c}{ IPP } \\
& 1999 & 2000 & Média* & 1999 & 2000 & Média* & 1999 & 2000 & Média* \\
\hline Cerrado & 3,37 & 3,36 & 3,37 & 3,40 & 3,53 & 3,47 & 2,95 & 3,11 & 3,03 \\
Goiabal & 3,20 & 3,15 & 3,18 & 3,24 & 3,00 & 3,12 & 3,06 & 3,23 & 3,15 \\
Milharal & 3,23 & 2,92 & 3,08 & 3,46 & 2,83 & 3,15 & 2,99 & 2,99 & 2,99 \\
\hline
\end{tabular}

* Índices calculados considerando as duas épocas de amostragem (total de 20 amostras para cada área). 


\section{CONCLUSÕES}

Do estudo desenvolvido, em que se compararam comunidades de nematóides presentes em três diferentes ecossistemas, conclui-se que: a) a retirada da vegetação nativa de cerrado e a implantação dos cultivos de goiabeira e milho influenciaram as comunidades, resultando em redução na abundância da superfamília Criconematoidea e da família Criconematidae, bem como ausência de Discocriconemella e Tylenchulus (todos grupos taxonômicos muito abundantes na vegetação original de cerrado), elevação nas abundâncias de Helicotylenchus e Pratylenchus e menores valores de riqueza de gêneros, diversidade trófica e abundância relativa de nematóides predadores ou onívoros; b) a similaridade com a área de cerrado foi menor quando o cultivo estabelecido foi o de milho; c) em relação ao cultivo de milho, ocorreu redução na abundância de Dorylaimellus e ausência de Dorylaimoides e Labronema (todos gêneros muito abundantes na vegetação original de cerrado). 
ANEXOS 
Tabela 1. Famílias de nematóides e abundâncias absolutas (A, números de indivíduos por $200 \mathrm{ml}$ de solo), abundâncias relativas (Ar\%), freqüências absolutas (F\%), freqüências relativas (Fr\%), valores de proeminência absolutos (VP) e valores de proeminência relativos (VP\%) de área de cerrado (médias de 10 amostras de solo coletadas em maio de 1999).

\begin{tabular}{lcccccc}
\hline Famílias & $\mathrm{A}$ & $\mathrm{Ar} \%$ & $\mathrm{~F} \%$ & $\mathrm{Fr} \%$ & $\mathrm{VP}$ & $\mathrm{VP} \%$ \\
\hline Qudsianematidae & 103,00 & 25,93 & 90 & 7,89 & 977,14 & 28,77 \\
Criconematidae & 69,00 & 17,37 & 80 & 7,02 & 617,15 & 18,17 \\
Tylenchulidae & 40,30 & 10,14 & 60 & 5,26 & 312,16 & 9,19 \\
Belondiridae & 34,60 & 8,71 & 100 & 8,77 & 346,00 & 10,19 \\
Cephalobidae & 31,70 & 7,98 & 80 & 7,02 & 283,53 & 8,35 \\
Leptonchidae & 23,40 & 5,89 & 80 & 7,02 & 209,29 & 6,16 \\
Mydonomidae & 15,90 & 4,00 & 70 & 6,14 & 133,03 & 3,92 \\
Hoplolaimidae & 14,10 & 3,55 & 70 & 6,14 & 117,97 & 3,47 \\
Rhabditidae & 8,70 & 2,19 & 50 & 4,38 & 61,52 & 1,81 \\
Aporcelaimidae & 7,60 & 1,91 & 50 & 4,38 & 53,74 & 1,58 \\
Mononchidae & 7,60 & 1,91 & 30 & 2,63 & 41,62 & 1,22 \\
Dorylaimidae & 6,50 & 1,64 & 30 & 2,63 & 35,60 & 1,05 \\
Tylenchidae & 6,00 & 1,51 & 40 & 3,51 & 37,94 & 1,12 \\
Diphtherophoridae & 5,70 & 1,45 & 70 & 6,14 & 47,69 & 1,40 \\
Nygolaimellidae & 5,70 & 1,45 & 50 & 4,38 & 40,30 & 1,19 \\
Nygolaimidae & 3,90 & 0,98 & 30 & 2,63 & 21,36 & 0,63 \\
Plectidae & 3,60 & 0,91 & 30 & 2,63 & 19,72 & 0,58 \\
Longidoridae & 2,20 & 0,55 & 20 & 1,75 & 9,84 & 0,29 \\
Tylencholaimidae & 2,10 & 0,53 & 20 & 1,75 & 9,39 & 0,28 \\
Anguinidae & 1,40 & 0,35 & 20 & 1,75 & 6,26 & 0,18 \\
Mylonchulidae & 1,00 & 0,25 & 10 & 0,88 & 3,16 & 0,09 \\
Nordiidae & 1,00 & 0,25 & 20 & 1,75 & 4,47 & 0,13 \\
Ironidae & 0,70 & 0,18 & 10 & 0,88 & 2,21 & 0,06
\end{tabular}


Tabela 1. Famílias de nematóides e abundâncias absolutas (A, números de indivíduos por $200 \mathrm{ml}$ de solo), abundâncias relativas (Ar\%), freqüências absolutas (F\%), freqüências relativas (Fr\%), valores de proeminência absolutos (VP) e valores de proeminência relativos (VP\%) de área de cerrado (médias de 10 amostras de solo coletadas em maio de 1999).

\begin{tabular}{lcccccc}
\hline Famílias & $\mathrm{A}$ & $\mathrm{Ar} \%$ & $\mathrm{~F} \%$ & Fr\% & VP & VP\% \\
\hline Teratocephalidae & 0,70 & 0,18 & 10 & 0,88 & 2,21 & 0,06 \\
Trichodoridae & 0,50 & 0,12 & 10 & 0,88 & 1,58 & 0,05 \\
Paraphelenchidae & 0,30 & 0,07 & 10 & 0,88 & 0,95 & 0,03 \\
\hline
\end{tabular}

Tabela 2. Gêneros de nematóides e abundâncias absolutas (A, números de indivíduos por $200 \mathrm{ml}$ de solo), abundâncias relativas (Ar\%), frequêencias absolutas (F\%), freqüências relativas (Fr\%), valores de proeminência absolutos (VP) e valores de proeminência relativos (VP\%) de área de cerrado (médias de 10 amostras de solo coletadas em maio de 1999).

\begin{tabular}{lcccccc}
\hline Gêneros & $\mathrm{A}$ & $\mathrm{Ar} \%$ & $\mathrm{~F} \%$ & $\mathrm{Fr} \%$ & $\mathrm{VP}$ & $\mathrm{VP} \%$ \\
\hline Discocriconemella & 70,30 & 17,70 & 90 & 6,04 & 666,92 & 22,31 \\
Tylenchulus & 40,00 & 10,07 & 60 & 4,03 & 309,84 & 10,31 \\
Labronema & 38,10 & 9,59 & 70 & 4,70 & 318,77 & 10,61 \\
Dorylaimellus & 32,00 & 8,06 & 90 & 6,04 & 303,58 & 10,10 \\
Acrobeles & 22,70 & 5,71 & 50 & 3,35 & 160,51 & 5,34 \\
Discolaimoides & 22,50 & 5,66 & 70 & 4,70 & 188,24 & 6,26 \\
Eudorylaimus & 21,20 & 5,34 & 70 & 4,70 & 177,37 & 5,90 \\
Dorylaimoides & 15,90 & 4,00 & 70 & 4,70 & 133,02 & 4,43 \\
Helicotylenchus & 13,10 & 3,30 & 60 & 4,03 & 101,47 & 3,38 \\
Basirotyleptus & 12,90 & 3,25 & 70 & 4,70 & 107,93 & 3,59 \\
Microdorylaimus & 9,90 & 2,49 & 50 & 3,35 & 70,00 & 2,33 \\
Discolaimium & 8,30 & 2,09 & 60 & 4,03 & 64,29 & 2,14 \\
Aporcelaimellus & 7,60 & 1,91 & 50 & 3,35 & 53,74 & 1,79 \\
Oriverutus & 6,40 & 1,61 & 30 & 2,01 & 35,05 & 1,16 \\
Nygolaimellus & 6,00 & 1,51 & 60 & 4,03 & 46,47 & 1,55
\end{tabular}


Tabela 2. Gêneros de nematóides e abundâncias absolutas (A, números de indivíduos por $200 \mathrm{ml}$ de solo), abundâncias relativas (Ar\%), freqüências absolutas (F\%), freqüências relativas (Fr\%), valores de proeminência absolutos (VP) e valores de proeminência relativos (VP\%) de área de cerrado (médias de 10 amostras de solo coletadas em maio de 1999).

\begin{tabular}{|c|c|c|c|c|c|c|}
\hline Gêneros & $\bar{A}$ & Ar\% & F\% & Fr\% & VP & VP\% \\
\hline Diphtherophora & 5,70 & 1,43 & 70 & 4,70 & 47,69 & 1,59 \\
\hline Mesodorylaimus & 5,20 & 1,31 & 20 & 1,34 & 23,25 & 0,77 \\
\hline Leptonchus & 3,70 & 0,93 & 30 & 2,01 & 20,26 & 0,67 \\
\hline Rhabditis & 3,40 & 0,85 & 20 & 1,34 & 15,20 & 0,50 \\
\hline Eucephalobus & 3,30 & 0,83 & 20 & 1,34 & 14,76 & 0,49 \\
\hline Acrobeloides & 3,10 & 0,78 & 20 & 1,34 & 13,86 & 0,46 \\
\hline Clarkus & 3,10 & 0,78 & 20 & 1,34 & 13,86 & 0,46 \\
\hline Ecumenicus & 2,70 & 0,68 & 10 & 0,67 & 8,54 & 0,28 \\
\hline Wilsonema & 2,60 & 0,65 & 10 & 0,67 & 8,22 & 0,27 \\
\hline Xiphinema & 2,20 & 0,55 & 20 & 1,34 & 9,84 & 0,33 \\
\hline Mononchus & 2,10 & 0,53 & 20 & 1,34 & 9,39 & 0,31 \\
\hline Dactyluroxonchium & 1,90 & 0,48 & 10 & 0,67 & 6,00 & 0,20 \\
\hline Ditylenchus & 1,40 & 0,35 & 20 & 1,34 & 6,26 & 0,21 \\
\hline Enchodelus & 1,30 & 0,33 & 10 & 0,67 & 4,11 & 0,14 \\
\hline Opisthodorylaimus & 1,30 & 0,33 & 10 & 0,67 & 4,11 & 0,14 \\
\hline Cruznema & 1,10 & 0,28 & 10 & 0,67 & 3,48 & 0,12 \\
\hline Tylencholaimus & 1,10 & 0,28 & 10 & 0,67 & 3,48 & 0,12 \\
\hline Aorolaimus & 1,00 & 0,25 & 20 & 1,34 & 4,47 & 0,15 \\
\hline Cephalobus & 1,00 & 0,25 & 20 & 1,34 & 4,47 & 0,15 \\
\hline Chitwoodius & 1,00 & 0,25 & 20 & 1,34 & 4,47 & 0,15 \\
\hline Plectus & 1,00 & 0,25 & 20 & 1,34 & 4,47 & 0,15 \\
\hline Sporonchulus & 1,00 & 0,25 & 10 & 0,67 & 3,16 & 0,11 \\
\hline Axonchium & 0,70 & 0,18 & 10 & 0,67 & 2,21 & 0,07 \\
\hline Euteratocephalus & 0,70 & 0,18 & 10 & 0,67 & 2,21 & 0,07 \\
\hline Ironus & 0,70 & 0,18 & 10 & 0,67 & 2,21 & 0,07 \\
\hline
\end{tabular}


Tabela 2. Gêneros de nematóides e abundâncias absolutas (A, números de indivíduos por $200 \mathrm{ml}$ de solo), abundâncias relativas (Ar\%), freqüências absolutas ( $\mathrm{F} \%$ ), freqüências relativas (Fr\%), valores de proeminência absolutos (VP) e valores de proeminência relativos (VP\%) de área de cerrado (médias de 10 amostras de solo coletadas em maio de 1999).

\begin{tabular}{lcccccc}
\hline Gêneros & $\mathrm{A}$ & $\mathrm{Ar} \%$ & $\mathrm{~F} \%$ & $\mathrm{Fr} \%$ & $\mathrm{VP}$ & $\mathrm{VP} \%$ \\
\hline Tyleptus & 0,70 & 0,18 & 10 & 0,67 & 2,21 & 0,07 \\
Chiloplacus & 0,60 & 0,15 & 10 & 0,67 & 1,90 & 0,06 \\
Paratrichodorus & 0,50 & 0,12 & 10 & 0,67 & 1,58 & 0,05 \\
Tylencholaimellus & 0,50 & 0,12 & 10 & 0,67 & 1,58 & 0,05 \\
Glochidorella & 0,30 & 0,07 & 10 & 0,67 & 0,95 & 0,03 \\
Meylis & 0,30 & 0,07 & 10 & 0,67 & 0,95 & 0,03 \\
Mylodiscus & 0,30 & 0,07 & 10 & 0,67 & 0,95 & 0,03 \\
Paraphelenchus & 0,30 & 0,07 & 10 & 0,67 & 0,95 & 0,03 \\
Paratylenchus & 0,30 & 0,07 & 10 & 0,67 & 0,95 & 0,03 \\
\hline
\end{tabular}

Tabela 3. Famílias de nematóides e abundâncias absolutas (A, números de indivíduos por $5 \mathrm{~g}$ de raizes), abundâncias relativas (Ar\%), freqüências absolutas ( $\mathrm{F} \%)$, freqüências relativas (Fr\%), valores de proeminência absolutos (VP) e valores de proeminência relativos (VP\%) de área de cerrado (médias de 10 amostras de raízes coletadas em maio de 1999 ).

\begin{tabular}{lcccccc}
\hline Famílias & $\mathrm{A}$ & $\mathrm{Ar} \%$ & $\mathrm{~F} \%$ & Fr\% & VP & VP\% \\
\hline Tylenchidae & 24,50 & 53,49 & 60 & 26,09 & 189,78 & 59,75 \\
Tylenchulidae & 8,40 & 18,34 & 40 & 17,39 & 53,13 & 16,72 \\
Aphelenchidae & 4,30 & 9,39 & 40 & 17,39 & 27,19 & 8,56 \\
Hoplolaimidae & 4,30 & 9,39 & 50 & 21,74 & 30,40 & 9,57 \\
Pratylenchidae & 2,70 & 5,89 & 20 & 8,69 & 12,07 & 3,80 \\
Anguinidae & 1,10 & 2,41 & 10 & 4,35 & 3,48 & 1,09 \\
Criconematidae & 0,50 & 1,09 & 10 & 4,35 & 1,58 & 0,50 \\
\hline
\end{tabular}


Tabela 4. Gêneros de nematóides e abundâncias absolutas (A, números de indivíduos por $5 \mathrm{~g}$ de raízes), abundâncias relativas (Ar\%), freqüências absolutas ( $\mathrm{F} \%)$, freqüências relativas $(\mathrm{Fr} \%)$, valores de proeminência absolutos (VP) e valores de proeminência relativos (VP\%) de área de cerrado (médias de 10 amostras de raízes coletadas em maio de 1999 ).

\begin{tabular}{lcccccc}
\hline Gêneros & $\mathrm{A}$ & $\mathrm{Ar} \%$ & $\mathrm{~F} \%$ & Fr\% & VP & VP\% \\
\hline Paratylenchus & 6,80 & 14,85 & 30 & 17,65 & 37,24 & 31,82 \\
Aphelenchus & 4,30 & 9,39 & 40 & 23,53 & 27,19 & 23,23 \\
Helicotylenchus & 4,30 & 9,39 & 50 & 29,41 & 30,40 & 25,98 \\
Pratylenchus & 2,70 & 5,90 & 20 & 11,76 & 12,07 & 10,31 \\
Tylenchulus & 1,60 & 3,49 & 10 & 5,88 & 5,06 & 4,32 \\
Ditylenchus & 1,10 & 2,40 & 10 & 5,88 & 3,48 & 2,97 \\
Discocriconemella & 0,50 & 1,09 & 10 & 5,88 & 1,58 & 1,35 \\
\hline
\end{tabular}

Tabela 5. Famílias de nematóides e abundâncias absolutas (A, números de indivíduos por $200 \mathrm{ml}$ de solo), abundâncias relativas (Ar\%), frequeências absolutas (F\%), freqüências relativas (Fr\%), valores de proeminência absolutos (VP) e valores de proeminência relativos (VP\%) de área de goiabal (médias de 10 amostras de solo coletadas em maio de 1999).

\begin{tabular}{lcccccc}
\hline Famílias & $\mathrm{A}$ & $\mathrm{Ar} \%$ & $\mathrm{~F} \%$ & Fr\% & VP & VP\% \\
\hline Hoplolaimidae & 319,00 & 48,32 & 100 & 8,40 & 3190,00 & 51,19 \\
Qudsianematidae & 71,10 & 10,77 & 100 & 8,40 & 711,00 & 11,41 \\
Cephalobidae & 51,70 & 7,83 & 100 & 8,40 & 517,00 & 8,29 \\
Rhabditidae & 44,80 & 6,79 & 90 & 7,56 & 425,01 & 6,82 \\
Belondiridae & 39,50 & 5,98 & 90 & 7,56 & 374,73 & 6,01 \\
Dorylaimidae & 34,20 & 5,18 & 90 & 7,56 & 324,45 & 5,21 \\
Longidoridae & 19,80 & 3,00 & 50 & 4,20 & 140,00 & 2,25 \\
Diphtherophoridae & 18,90 & 2,86 & 80 & 6,72 & 169,05 & 2,71 \\
Tylenchidae & 12,40 & 1,88 & 70 & 5,88 & 103,74 & 1,66
\end{tabular}


Tabela 5. Famílias de nematóides e abundâncias absolutas (A, números de indivíduos por $200 \mathrm{ml}$ de solo), abundâncias relativas (Ar\%), freqüências absolutas (F\%), freqüências relativas ( $\mathrm{Fr} \%)$, valores de proeminência absolutos (VP) e valores de proeminência relativos (VP\%) de área de goiabal (médias de 10 amostras de solo coletadas em maio de 1999).

\begin{tabular}{lcccccc}
\hline Famílias & $\mathrm{A}$ & $\mathrm{Ar} \%$ & $\mathrm{~F} \%$ & Fr\% & VP & VP\% \\
\hline Mylonchulidae & 10,40 & 1,58 & 70 & 5,88 & 87,01 & 1,40 \\
Tylencholaimidae & 8,00 & 1,21 & 50 & 4,20 & 56,57 & 0,91 \\
Monhysteridae & 7,50 & 1,14 & 40 & 3,36 & 47,43 & 0,76 \\
Aphelenchidae & 5,00 & 0,76 & 50 & 4,20 & 35,35 & 0,57 \\
Criconematidae & 2,50 & 0,38 & 20 & 1,68 & 11,18 & 0,18 \\
Carcharolaimidae & 2,40 & 0,36 & 20 & 1,68 & 10,73 & 0,17 \\
Leptonchidae & 2,30 & 0,35 & 30 & 2,52 & 12,60 & 0,20 \\
Aporcelaimidae & 2,20 & 0,33 & 30 & 2,52 & 12,04 & 0,19 \\
Trichodoridae & 2,10 & 0,32 & 20 & 1,68 & 9,39 & 0,15 \\
Mononchidae & 2,00 & 0,30 & 10 & 0,84 & 6,32 & 0,10 \\
Mydonomidae & 1,60 & 0,24 & 10 & 0,84 & 5,06 & 0,08 \\
Plectidae & 1,10 & 0,17 & 20 & 1,68 & 4,92 & 0,08 \\
Aphelenchoididae & 0,90 & 0,14 & 10 & 0,84 & 2,85 & 0,04 \\
Chromadoridae & 0,20 & 0,03 & 10 & 0,84 & 0,63 & 0,01 \\
Nygolaimidae & 0,20 & 0,03 & 10 & 0,84 & 0,63 & 0,01 \\
Panagrolaimidae & 0,20 & 0,03 & 10 & 0,84 & 0,63 & 0,01 \\
Paraphelenchidae & 0,20 & 0,03 & 10 & 0,84 & 0,63 & 0,01 \\
\hline
\end{tabular}


Tabela 6. Gêneros de nematóides e abundâncias absolutas (A, números de indivíduos por $200 \mathrm{ml} \mathrm{de} \mathrm{solo),} \mathrm{abundâncias} \mathrm{relativas} \mathrm{(Ar \% ),} \mathrm{freqüências} \mathrm{absolutas} \mathrm{(F \% ),}$ freqüências relativas ( $\mathrm{Fr} \%)$, valores de proeminência absolutos (VP) e valores de proeminência relativos (VP\%) de área de goiabal (médias de 10 amostras de solo coletadas em maio de 1999).

\begin{tabular}{lcccccc}
\hline Gêneros & $\mathrm{A}$ & $\mathrm{Ar} \%$ & $\mathrm{~F} \%$ & $\mathrm{Fr} \%$ & $\mathrm{VP}$ & $\mathrm{VP} \%$ \\
\hline Helicotylenchus & 319,00 & 48,32 & 100 & 6,90 & 3190,00 & 56,36 \\
Acrobeles & 38,60 & 5,85 & 100 & 6,90 & 386,00 & 6,82 \\
Dorylaimellus & 37,40 & 5,66 & 80 & 5,52 & 334,51 & 5,91 \\
Eudorylaimus & 33,80 & 5,12 & 100 & 6,90 & 338,00 & 5,97 \\
Rhabditis & 29,90 & 4,53 & 60 & 4,14 & 231,60 & 4,09 \\
Mesodorylaimus & 21,40 & 3,24 & 70 & 4,83 & 179,04 & 3,16 \\
Xiphinema & 19,80 & 3,00 & 60 & 4,14 & 153,37 & 2,71 \\
Diphtherophora & 18,50 & 2,80 & 80 & 5,52 & 165,47 & 2,92 \\
Discolaimium & 17,70 & 2,68 & 70 & 4,83 & 148,09 & 2,61 \\
Opisthodorylaimus & 12,80 & 1,94 & 60 & 4,14 & 99,15 & 1,75 \\
Mylonchulus & 10,40 & 1,58 & 70 & 4,83 & 87,01 & 1,54 \\
Eucephalobus & 8,00 & 1,21 & 50 & 3,45 & 56,57 & 1,00 \\
Prismatolaimus & 6,70 & 1,01 & 40 & 2,76 & 42,37 & 0,75 \\
Discolaimoides & 6,40 & 0,97 & 60 & 4,14 & 49,57 & 0,87 \\
Chitwoodius & 5,80 & 0,88 & 50 & 3,45 & 41,01 & 0,72 \\
Aphelenchus & 5,00 & 0,76 & 50 & 3,45 & 35,35 & 0,62 \\
Discolaimus & 3,90 & 0,59 & 20 & 1,38 & 17,44 & 0,31 \\
Belondira & 3,00 & 0,45 & 10 & 0,69 & 9,49 & 0,17 \\
Hemicycliophora & 2,50 & 0,38 & 20 & 1,38 & 11,18 & 0,20 \\
Carcharolaimus & 2,40 & 0,36 & 20 & 1,38 & 10,73 & 0,19 \\
Aporcelaimellus & 2,20 & 0,33 & 30 & 2,07 & 12,05 & 0,21 \\
Paratrichodorus & 2,10 & 0,32 & 20 & 1,38 & 9,39 & 0,17 \\
Mononchus & 2,00 & 0,30 & 10 & 0,69 & 6,32 & 0,11 \\
Dorylaimoides & 1,60 & 0,24 & 20 & 1,38 & 7,15 & 0,13
\end{tabular}


Tabela 6. Gêneros de nematóides e abundâncias absolutas (A, números de indivíduos por $200 \mathrm{ml}$ de solo), abundâncias relativas (Ar\%), frequêencias absolutas (F\%), freqüências relativas (Fr\%), valores de proeminência absolutos (VP) e valores de proeminência relativos (VP\%) de área de goiabal (médias de 10 amostras de solo coletadas em maio de 1999).

\begin{tabular}{lcccccc}
\hline Gêneros & $\mathrm{A}$ & $\mathrm{Ar} \%$ & $\mathrm{~F} \%$ & $\mathrm{Fr} \%$ & $\mathrm{VP}$ & $\mathrm{VP} \%$ \\
\hline Zeldia & 1,60 & 0,24 & 20 & 1,38 & 7,15 & 0,13 \\
Acrobeloides & 1,10 & 0,17 & 20 & 1,38 & 4,92 & 0,09 \\
Nygolaimus & 1,00 & 0,15 & 10 & 0,69 & 3,16 & 0,06 \\
Aphelenchoides & 0,90 & 0,14 & 10 & 0,69 & 2,85 & 0,05 \\
Axonchium & 0,90 & 0,14 & 10 & 0,69 & 2,85 & 0,05 \\
Ditylenchus & 0,90 & 0,14 & 10 & 0,69 & 2,85 & 0,05 \\
Labronema & 0,80 & 0,12 & 20 & 1,38 & 3,58 & 0,06 \\
Monhystera & 0,80 & 0,12 & 10 & 0,69 & 2,53 & 0,04 \\
Tylencholaimellus & 0,80 & 0,12 & 10 & 0,69 & 2,53 & 0,04 \\
Cephalobus & 0,60 & 0,09 & 20 & 1,38 & 2,68 & 0,05 \\
Leptonchus & 0,60 & 0,09 & 10 & 0,69 & 1,90 & 0,03 \\
Plectus & 0,50 & 0,07 & 10 & 0,69 & 1,58 & 0,03 \\
Chiloplacus & 0,40 & 0,06 & 10 & 0,69 & 1,26 & 0,02 \\
Panagrolaimus & 0,20 & 0,03 & 10 & 0,69 & 0,63 & 0,01 \\
Paraphelenchus & 0,20 & 0,03 & 10 & 0,69 & 0,63 & 0,01 \\
Wilsonema & 0,20 & 0,03 & 10 & 0,69 & 0,63 & 0,01 \\
\hline
\end{tabular}


Tabela 7. Famílias de nematóides e abundâncias absolutas (A, números de indivíduos por $5 \mathrm{~g}$ de raízes), abundâncias relativas (Ar\%), freqüências absolutas (F\%), freqüências relativas $(\mathrm{Fr} \%)$, valores de proeminência absolutos (VP) e valores de proeminência relativos (VP\%) de área de goiabal (médias de 10 amostras de raízes coletadas em maio de 1999).

\begin{tabular}{lcccccc}
\hline Famílias & A & Ar\% & F\% & Fr\% & VP & VP\% \\
\hline Hoplolaimidae & 40,70 & 57,73 & 100 & 38,46 & 407,00 & 62,08 \\
Pratylenchidae & 17,50 & 24,82 & 90 & 34,61 & 166,00 & 25,32 \\
Tylenchidae & 10,60 & 15,01 & 50 & 19,23 & 74,95 & 11,43 \\
Aphelenchidae & 1,70 & 2,41 & 20 & 7,69 & 7,60 & 1,16 \\
\hline
\end{tabular}

Tabela 8. Gêneros de nematóides e abundâncias absolutas (A, números de indivíduos por $5 \mathrm{~g}$ de raízes), abundâncias relativas (Ar\%), freqüências absolutas ( $\mathrm{F} \%)$, freqüências relativas (Fr\%), valores de proeminência absolutos (VP) e valores de proeminência relativos (VP\%) de área de goiabal (médias de 10 amostras de raízes coletadas em maio de 1999).

\begin{tabular}{lcccccc}
\hline Gêneros & $\mathrm{A}$ & $\mathrm{Ar} \%$ & $\mathrm{~F} \%$ & $\mathrm{Fr} \%$ & $\mathrm{VP}$ & $\mathrm{VP} \%$ \\
\hline Helicotylenchus & 40,70 & 57,73 & 100 & 47,62 & 407,00 & 70,10 \\
Pratylenchus & 17,50 & 24,82 & 90 & 42,86 & 166,00 & 28,59 \\
Aphelenchus & 1,70 & 2,41 & 20 & 9,52 & 7,60 & 1,31 \\
\hline
\end{tabular}

Tabela 9. Famílias de nematóides e abundâncias absolutas (A, números de indivíduos por $200 \mathrm{ml}$ de solo), abundâncias relativas (Ar\%), freqüências absolutas (F\%), freqüências relativas (Fr\%), valores de proeminência absolutos (VP) e valores de proeminência relativos (VP\%) de área de milharal (médias de 10 amostras de solo coletadas em maio de 1999).

\begin{tabular}{lcccccc}
\hline Famílias & A & Ar\% & F\% & Fr\% & VP & VP\% \\
\hline Hoplolaimidae & 547,20 & 30,48 & 100 & 6,85 & 5472,00 & 31,55 \\
Pratylenchidae & 371,30 & 20,68 & 100 & 6,85 & 3713,00 & 21,41 \\
Dorylaimidae & 170,00 & 9,47 & 100 & 6,85 & 1700,00 & 9,80 \\
Qudsianematidae & 162,30 & 9,04 & 100 & 6,85 & 1623,00 & 9,36 \\
Cephalobidae & 156,20 & 8,70 & 100 & 6,85 & 1562,00 & 9,00
\end{tabular}


Tabela 9. Famílias de nematóides e abundâncias absolutas (A, números de indivíduos por $200 \mathrm{ml}$ de solo), abundâncias relativas (Ar\%), freqüências absolutas (F\%), freqüências relativas (Fr\%), valores de proeminência absolutos (VP) e valores de proeminência relativos (VP\%) de área de milharal (médias de 10 amostras de solo coletadas em maio de 1999).

\begin{tabular}{lcccccc}
\hline Famílias & $\mathrm{A}$ & Ar\% & F\% & Fr\% & VP & VP\% \\
\hline Aporcelaimidae & 75,60 & 4,21 & 90 & 6,16 & 717,20 & 4,13 \\
Tylenchidae & 58,00 & 3,23 & 80 & 5,48 & 518,77 & 2,99 \\
Nygolaimellidae & 43,30 & 2,41 & 80 & 5,48 & 387,29 & 2,23 \\
Tylencholaimidae & 40,60 & 2,26 & 80 & 5,48 & 363,13 & 2,09 \\
Plectidae & 29,40 & 1,64 & 80 & 5,48 & 262,96 & 1,52 \\
Longidoridae & 25,40 & 1,41 & 80 & 5,48 & 227,18 & 1,31 \\
Rhabditidae & 24,70 & 1,38 & 60 & 4,11 & 191,32 & 1,10 \\
Diphtherophoridae & 22,50 & 1,25 & 70 & 4,79 & 188,25 & 1,08 \\
Aphelenchidae & 16,50 & 0,92 & 60 & 4,11 & 127,81 & 0,74 \\
Mylonchulidae & 11,80 & 0,66 & 70 & 4,79 & 98,72 & 0,57 \\
Panagrolaimidae & 6,60 & 0,37 & 30 & 2,05 & 36,15 & 0,21 \\
Anguinidae & 5,70 & 0,32 & 20 & 1,37 & 25,49 & 0,15 \\
Belondiridae & 5,20 & 0,29 & 20 & 1,37 & 23,25 & 0,13 \\
Monhysteridae & 4,60 & 0,26 & 30 & 2,05 & 25,19 & 0,14 \\
Carcharolaimidae & 4,50 & 0,25 & 30 & 2,05 & 24,65 & 0,14 \\
Paraphelenchidae & 3,90 & 0,22 & 20 & 1,37 & 17,44 & 0,10 \\
Aphelenchoididae & 3,50 & 0,19 & 20 & 1,37 & 15,65 & 0,09 \\
Mononchidae & 3,00 & 0,17 & 20 & 3,42 & 13,42 & 0,08 \\
Cyatholaimidae & 2,30 & 0,13 & 10 & 0,68 & 7,27 & 0,04 \\
Criconematidae & 1,00 & 0,06 & 10 & 0,68 & 3,16 & 0,02 \\
\hline & & & & & &
\end{tabular}


Tabela 10. Gêneros de nematóides e abundâncias absolutas (A, números de indivíduos por $200 \mathrm{ml}$ de solo), abundâncias relativas (Ar\%), freqüências absolutas ( $\mathrm{F} \%)$, freqüências relativas (Fr\%), valores de proeminência absolutos (VP) e valores de proeminência relativos (VP\%) de área de milharal (médias de 10 amostras de solo coletadas em maio de 1999).

\begin{tabular}{|c|c|c|c|c|c|c|}
\hline Gêneros & A & $\mathrm{Ar} \%$ & F\% & Fr\% & VP & VP\% \\
\hline Helicotylenchus & 547,20 & 30,48 & 100 & 5,40 & 5472,00 & 33,63 \\
\hline Pratylenchus & 371,30 & 20,68 & 100 & 5,40 & 3713,00 & 22,82 \\
\hline Eudorylaimus & 109,00 & 6,07 & 100 & 5,40 & 1090,00 & 6,70 \\
\hline Opisthodorylaimus & 109,00 & 6,07 & 100 & 5,40 & 1090,00 & 6,70 \\
\hline Acrobeles & 91,40 & 5,09 & 100 & 5,40 & 914,00 & 5,61 \\
\hline Aporcelaimellus & 69,30 & 3,86 & 90 & 4,86 & 657,44 & 4,04 \\
\hline Mesodorylaimus & 56,00 & 3,12 & 90 & 4,86 & 513,26 & 3,26 \\
\hline Nygolaimellus & 43,30 & 2,41 & 80 & 4,32 & 387,29 & 2,38 \\
\hline Chitwoodius & 37,70 & 2,10 & 80 & 4,32 & 337,20 & 2,07 \\
\hline Discolaimium & 31,40 & 1,75 & 70 & 3,78 & 262,71 & 1,61 \\
\hline Eucephalobus & 30,90 & 1,72 & 70 & 3,78 & 258,53 & 1,59 \\
\hline Plectus & 29,40 & 1,64 & 80 & 4,32 & 262,96 & 1,61 \\
\hline Xiphinema & 25,40 & 1,41 & 80 & 4,32 & 227,18 & 1,31 \\
\hline Zeldia & 24,90 & 1,39 & 70 & 3,78 & 208,33 & 1,20 \\
\hline Diphtherophora & 22,50 & 1,25 & 70 & 3,78 & 188,25 & 1,08 \\
\hline Aphelenchus & 16,50 & 0,92 & 60 & 3,24 & 127,81 & 0,74 \\
\hline Mylonchulus & 11,80 & 0,66 & 70 & 3,78 & 98,72 & 0,57 \\
\hline Rhabditis & 10,20 & 0,57 & 50 & 2,70 & 72,12 & 0,41 \\
\hline Discolaimoides & 10,10 & 0,56 & 50 & 2,70 & 71,42 & 0,41 \\
\hline Discolaimus & 8,20 & 0,46 & 20 & 1,08 & 36,67 & 0,21 \\
\hline Panagrolaimus & 6,60 & 0,37 & 30 & 1,62 & 36,15 & 0,21 \\
\hline Sporonchulus & 6,00 & 0,33 & 30 & 1,62 & 32,86 & 0,19 \\
\hline Prionchulus & 5,90 & 0,32 & 30 & 1,62 & 32,31 & 0,19 \\
\hline Ditylenchus & 5,70 & 0,31 & 20 & 1,08 & 25,49 & 0,15 \\
\hline
\end{tabular}


Tabela 10. Gêneros de nematóides e abundâncias absolutas ( $\mathrm{A}$, números de indivíduos por $200 \mathrm{ml}$ de solo), abundâncias relativas (Ar\%), freqüências absolutas (F\%), freqüências relativas $(\mathrm{Fr} \%)$, valores de proeminência absolutos (VP) e valores de proeminência relativos (VP\%) de área de milharal (médias de 10 amostras de solo coletadas em maio de 1999).

\begin{tabular}{lcccccc}
\hline Gêneros & $\mathrm{A}$ & $\mathrm{Ar} \%$ & $\mathrm{~F} \%$ & $\mathrm{Fr} \%$ & $\mathrm{VP}$ & $\mathrm{VP} \%$ \\
\hline Carcharolaimus & 4,50 & 0,25 & 30 & 1,62 & 24,65 & 0,14 \\
Paraphelenchus & 3,90 & 0,22 & 20 & 1,08 & 17,44 & 0,10 \\
Aphelenchoides & 3,50 & 0,19 & 20 & 1,08 & 15,65 & 0,09 \\
Amphidorylaimus & 3,20 & 0,18 & 20 & 1,08 & 14,31 & 0,08 \\
Mononchus & 3,00 & 0,17 & 20 & 1,08 & 13,42 & 0,07 \\
Axonchium & 2,90 & 0,16 & 10 & 0,54 & 9,17 & 0,05 \\
Tylencholaimus & 2,90 & 0,16 & 10 & 0,54 & 9,17 & 0,05 \\
Achromadora & 2,30 & 0,13 & 10 & 0,54 & 7,27 & 0,04 \\
Chiloplacus & 2,30 & 0,13 & 10 & 0,54 & 7,27 & 0,04 \\
Dorylaimellus & 2,30 & 0,13 & 10 & 0,54 & 7,27 & 0,04 \\
Mesorhabditis & 2,30 & 0,13 & 10 & 0,54 & 7,27 & 0,04 \\
Monhystera & 1,80 & 0,10 & 10 & 0,54 & 5,69 & 0,03 \\
Ecumenicus & 1,50 & 0,08 & 10 & 0,54 & 4,74 & 0,02 \\
Prismatolaimus & 1,50 & 0,08 & 20 & 1,08 & 6,71 & 0,04 \\
Criconemella & 1,00 & 0,06 & 10 & 0,54 & 3,16 & 0,01 \\
\hline
\end{tabular}


Tabela 11. Famílias de nematóides e abundâncias absolutas (A, números de indivíduos por $5 \mathrm{~g}$ de raízes), abundâncias relativas (Ar\%), freqüências absolutas ( $\mathrm{F} \%)$, freqüências relativas (Fr\%), valores de proeminência absolutos (VP) e valores de proeminência relativos (VP\%) de área de milharal (médias de 10 amostras de raízes coletadas em maio de 1999).

\begin{tabular}{lcccccc}
\hline Famílias & A & Ar\% & F\% & Fr\% & VP & VP\% \\
\hline Pratylenchidae & 1007,80 & 87,33 & 100 & 25,00 & 10078,00 & 87,74 \\
Hoplolaimidae & 77,70 & 6,73 & 90 & 22,50 & 737,13 & 6,42 \\
Aphelenchoididae & 36,90 & 3,20 & 100 & 25,00 & 369,00 & 3,21 \\
Tylenchidae & 29,60 & 2,56 & 100 & 25,00 & 296,00 & 2,58 \\
Aphelenchidae & 2,00 & 0,17 & 10 & 2,50 & 6,32 & 0,05 \\
\hline
\end{tabular}

Tabela 12. Gêneros de nematóides e abundâncias absolutas (A, números de indivíduos por $5 \mathrm{~g}$ de raízes), abundâncias relativas (Ar\%), freqüências absolutas (F\%), freqüências relativas $(\mathrm{Fr} \%)$, valores de proeminência absolutos (VP) e valores de proeminência relativos (VP\%) de área de milharal (médias de 10 amostras de raízes coletadas em maio de 1999).

\begin{tabular}{lcccccc}
\hline Gêneros & $\mathrm{A}$ & $\mathrm{Ar} \%$ & $\mathrm{~F} \%$ & $\mathrm{Fr} \%$ & $\mathrm{VP}$ & $\mathrm{VP} \%$ \\
\hline Pratylenchus & 1007,80 & 87,33 & 100 & 33,33 & 10078,00 & 90,06 \\
Helicotylenchus & 77,70 & 6,73 & 90 & 30,00 & 737,13 & 6,58 \\
Aphelenchoides & 36,90 & 3,20 & 100 & 33,33 & 369,00 & 3,30 \\
Aphelenchus & 2,00 & 0,17 & 10 & 3,33 & 6,32 & 0,06 \\
\hline
\end{tabular}

Tabela 13. Famílias de nematóides e abundâncias absolutas (A, números de indivíduos por $200 \mathrm{ml}$ de solo), abundâncias relativas (Ar\%), freqüências absolutas (F\%), freqüências relativas (Fr\%), valores de proeminência absolutos (VP) e valores de proeminência relativos (VP\%) de área de cerrado (médias de 10 amostras de solo coletadas em fevereiro de 2000).

\begin{tabular}{lcccccc}
\hline Famílias & A & Ar\% & F\% & Fr\% & VP & VP\% \\
\hline Criconematidae & 99,00 & 31,08 & 100 & 7,94 & 990,00 & 33,45 \\
Qudsianematidae & 72,10 & 22,64 & 100 & 7,94 & 721,00 & 24,36 \\
Cephalobidae & 37,70 & 11,84 & 100 & 7,94 & 377,00 & 12,74
\end{tabular}


Tabela 13. Famílias de nematóides e abundâncias absolutas (A, números de indivíduos por $200 \mathrm{ml}$ de solo), abundâncias relativas (Ar\%), freqüências absolutas (F\%), freqüências relativas (Fr\%), valores de proeminência absolutos (VP) e valores de proeminência relativos (VP\%) de área de cerrado (médias de 10 amostras de solo coletadas em fevereiro de 2000).

\begin{tabular}{lcccccc}
\hline Famílias & $\mathrm{A}$ & $\mathrm{Ar} \%$ & $\mathrm{~F} \%$ & $\mathrm{Fr} \%$ & $\mathrm{VP}$ & $\mathrm{VP} \%$ \\
\hline Dorylaimidae & 16,10 & 5,06 & 70 & 5,55 & 134,70 & 4,55 \\
Leptonchidae & 12,20 & 3,83 & 90 & 7,14 & 115,74 & 3,91 \\
Rhabditidae & 11,20 & 3,52 & 60 & 4,76 & 86,75 & 2,93 \\
Aporcelaimidae & 10,60 & 3,33 & 90 & 7,14 & 100,56 & 3,40 \\
Mydonomidae & 9,40 & 2,96 & 80 & 6,35 & 84,08 & 2,84 \\
Belondiridae & 9,00 & 2,83 & 80 & 6,35 & 80,50 & 2,72 \\
Hoplolaimidae & 8,10 & 2,54 & 40 & 3,17 & 51,23 & 1,73 \\
Alaimidae & 6,80 & 2,13 & 90 & 7,14 & 64,51 & 2,18 \\
Longidoridae & 4,20 & 1,32 & 50 & 3,97 & 29,70 & 1,00 \\
Nordiidae & 3,90 & 1,22 & 50 & 3,97 & 27,58 & 0,93 \\
Mylonchulidae & 3,70 & 1,16 & 30 & 2,38 & 20,26 & 0,68 \\
Tylencholaimidae & 3,40 & 1,07 & 60 & 4,76 & 26,34 & 0,89 \\
Mononchidae & 2,80 & 0,88 & 20 & 1,59 & 12,52 & 0,42 \\
Tylenchulidae & 2,00 & 0,63 & 20 & 1,59 & 8,94 & 0,30 \\
Monhysteridae & 1,40 & 0,44 & 30 & 2,38 & 7,67 & 0,26 \\
Diphtherophoridae & 1,10 & 0,34 & 20 & 1,59 & 4,92 & 0,16 \\
Nygolaimidae & 1,00 & 0,31 & 20 & 1,59 & 4,47 & 0,15 \\
Tylenchidae & 0,90 & 0,28 & 30 & 2,38 & 4,93 & 0,16 \\
Dorylaimidae & 0,80 & 0,25 & 10 & 0,79 & 2,53 & 0,08 \\
Nygolaimellidae & 0,70 & 0,22 & 10 & 0,79 & 2,21 & 0,07 \\
Ironidae & 0,40 & 0,12 & 10 & 0,79 & 1,26 & 0,04 \\
\hline
\end{tabular}


Tabela 14. Gêneros de nematóides e abundâncias absolutas (A, números de indivíduos por $200 \mathrm{ml}$ de solo), abundâncias relativas (Ar\%), frequeências absolutas (F\%), freqüências relativas ( $\mathrm{Fr} \%)$, valores de proeminência absolutos (VP) e valores de proeminência relativos (VP\%) de área de cerrado (médias de 10 amostras de solo coletadas em fevereiro de 2000).

\begin{tabular}{lcccccc}
\hline Gêneros & $\mathrm{A}$ & $\mathrm{Ar} \%$ & $\mathrm{~F} \%$ & $\mathrm{Fr} \%$ & $\mathrm{VP}$ & $\mathrm{VP} \%$ \\
\hline Discocriconemella & 74,60 & 23,42 & 70 & 3,82 & 624,15 & 25,76 \\
Acrobeles & 28,30 & 8,88 & 100 & 5,46 & 283,00 & 11,68 \\
Eudorylaimus & 19,40 & 6,09 & 90 & 4,92 & 184,00 & 7,60 \\
Labronema & 19,00 & 5,96 & 100 & 5,46 & 190,00 & 7,84 \\
Mesodorylaimus & 16,20 & 5,09 & 80 & 4,37 & 144,90 & 5,98 \\
Criconemella & 16,10 & 5,05 & 30 & 1,64 & 88,18 & 3,64 \\
Discolaimium & 13,20 & 4,14 & 80 & 4,37 & 118,06 & 4,87 \\
Aporcelaimellus & 10,60 & 3,33 & 90 & 4,92 & 100,56 & 4,15 \\
Dorylaimoides & 9,40 & 2,95 & 80 & 4,37 & 84,08 & 3,47 \\
Hemicriconemoides & 8,30 & 2,60 & 10 & 0,55 & 26,25 & 1,08 \\
Ecumenicus & 8,00 & 2,51 & 60 & 3,28 & 61,97 & 2,55 \\
Helicotylenchus & 7,50 & 2,35 & 30 & 1,64 & 41,08 & 1,69 \\
Dorylaimellus & 7,10 & 2,23 & 70 & 3,82 & 59,40 & 2,45 \\
Alaimus & 6,80 & 2,13 & 90 & 4,92 & 64,51 & 2,66 \\
Discolaimoides & 6,60 & 2,07 & 90 & 4,92 & 62,61 & 2,58 \\
Microdorylaimus & 5,30 & 1,66 & 60 & 3,28 & 41,05 & 1,69 \\
Xiphinema & 4,20 & 1,32 & 50 & 2,73 & 29,70 & 1,22 \\
Basirotyleptus & 3,80 & 1,19 & 50 & 2,73 & 26,87 & 1,11 \\
Acrobeloides & 3,10 & 0,97 & 40 & 2,18 & 19,61 & 0,81 \\
Eucephalobus & 3,10 & 0,97 & 40 & 2,18 & 10,61 & 0,81 \\
Leptonchus & 2,80 & 0,88 & 30 & 1,64 & 15,34 & 0,63 \\
Meylis & 2,60 & 0,82 & 10 & 0,55 & 8,22 & 0,34 \\
Sporonchulus & 2,50 & 0,78 & 20 & 1,09 & 11,18 & 0,46 \\
Tylencholaimus & 2,20 & 0,69 & 50 & 2,73 & 15,56 & 0,64
\end{tabular}


Tabela 14 . Gêneros de nematóides e abundâncias absolutas (A, números de indivíduos por $200 \mathrm{ml}$ de solo), abundâncias relativas (Ar\%), freqüências absolutas (F\%), freqüências relativas $(\mathrm{Fr} \%)$, valores de proeminência absolutos (VP) e valores de proeminência relativos (VP\%) de área de cerrado (médias de 10 amostras de solo coletadas em fevereiro de 2000).

\begin{tabular}{lcccccc}
\hline Gêneros & $\mathrm{A}$ & $\mathrm{Ar} \%$ & $\mathrm{~F} \%$ & $\mathrm{Fr} \%$ & $\mathrm{VP}$ & $\mathrm{VP} \%$ \\
\hline Tylenchulus & 2,20 & 0,69 & 30 & 1,64 & 12,05 & 0,49 \\
Cruznema & 2,00 & 0,63 & 40 & 2,18 & 12,65 & 0,52 \\
Enchodelus & 2,00 & 0,63 & 20 & 1,09 & 8,94 & 0,37 \\
Oriverutus & 1,90 & 0,60 & 40 & 2,18 & 12,02 & 0,49 \\
Mylodiscus & 1,80 & 0,56 & 30 & 1,64 & 9,86 & 0,40 \\
Axonchium & 1,70 & 0,53 & 30 & 1,64 & 9,31 & 0,38 \\
Clarkus & 1,40 & 0,44 & 10 & 0,55 & 4,43 & 0,18 \\
Prionchulus & 1,40 & 0,44 & 20 & 1,09 & 6,26 & 0,26 \\
Prismatolaimus & 1,40 & 0,44 & 30 & 1,64 & 7,67 & 0,32 \\
Mylonchulus & 1,20 & 0,38 & 10 & 0,55 & 3,79 & 0,16 \\
Cephalobus & 1,10 & 0,34 & 20 & 1,09 & 4,92 & 0,20 \\
Diphtherophora & 1,10 & 0,34 & 20 & 1,09 & 4,92 & 0,20 \\
Nygolaimellus & 0,70 & 0,22 & 10 & 0,55 & 2,21 & 0,09 \\
Opisthodorylaimus & 0,70 & 0,22 & 10 & 0,55 & 2,21 & 0,09 \\
Chitwoodius & 0,60 & 0,19 & 20 & 1,09 & 2,68 & 0,11 \\
Aorolaimus & 0,60 & 0,19 & 10 & 0,55 & 1,90 & 0,08 \\
Ironus & 0,40 & 0,12 & 10 & 0,55 & 1,26 & 0,05 \\
Tylencholaimellus & 0,40 & 0,12 & 10 & 0,55 & 1,26 & 0,05 \\
Tyleptus & 0,40 & 0,12 & 10 & 0,55 & 1,26 & 0,05 \\
Chiloplacus & 0,30 & 0,09 & 10 & 0,55 & 0,95 & 0,04 \\
Dactyluraxonchium & 0,20 & 0,06 & 10 & 0,55 & 0,63 & 0,03 \\
Rhabditis & 0,20 & 0,06 & 10 & 0,55 & 0,63 & 0,03 \\
\hline
\end{tabular}


Tabela 15. Famílias de nematóides e abundâncias absolutas (A, números de indivíduos por $5 \mathrm{~g}$ de raízes), abundâncias relativas (Ar\%), freqüências absolutas (F\%), freqüências relativas (Fr\%), valores de proeminência absolutos (VP) e valores de proeminência relativos (VP\%) de área de cerrado (médias de 10 amostras de raízes coletadas em fevereiro de 2000).

\begin{tabular}{lcccccc}
\hline Famílias & $\mathrm{A}$ & $\mathrm{Ar} \%$ & $\mathrm{~F} \%$ & $\mathrm{Fr} \%$ & VP & VP\% \\
\hline Tylenchidae & 15,10 & 33,70 & 60 & 20,00 & 116,96 & 39,37 \\
Tylenchulidae & 8,70 & 19,42 & 80 & 26,66 & 77,81 & 26,19 \\
Criconematidae & 8,30 & 18,53 & 60 & 20,00 & 64,29 & 21,64 \\
Pratylenchidae & 6,20 & 13,84 & 20 & 6,67 & 27,58 & 9,28 \\
Hoplolaimidae & 3,90 & 8,70 & 50 & 16,67 & 27,60 & 9,29 \\
Aphelenchidae & 1,70 & 3,80 & 20 & 6,67 & 7,60 & 2,56 \\
Longidoridae & 0,90 & 2,01 & 10 & 3,34 & 2,85 & 0,96 \\
\hline
\end{tabular}

Tabela 16. Gêneros de nematóides e abundâncias absolutas ( $\mathrm{A}$, números de indivíduos por $5 \mathrm{~g}$ de raízes), abundâncias relativas (Ar\%), freqüências absolutas (F\%), freqüências relativas (Fr\%), valores de proeminência absolutos (VP) e valores de proeminência relativos (VP\%) de área de cerrado (médias de 10 amostras de raízes coletadas em fevereiro de 2000).

\begin{tabular}{lcccccc}
\hline Gêneros & A & Ar\% & F\% & Fr\% & VP & VP\% \\
\hline Discocriconemella & 8,30 & 18,53 & 60 & 25,00 & 64,29 & 34,53 \\
Pratylenchus & 6,20 & 13,84 & 20 & 8,33 & 27,73 & 14,89 \\
Tylenchulus & 5,50 & 12,28 & 70 & 29,17 & 46,02 & 24,72 \\
Helicotylenchus & 3,90 & 8,70 & 50 & 20,83 & 27,58 & 14,81 \\
Paratylenchus & 3,20 & 7,14 & 10 & 4,17 & 10,12 & 5,43 \\
Aphelenchus & 1,70 & 3,80 & 20 & 8,33 & 7,60 & 4,08 \\
Xiphinema & 0,90 & 2,01 & 10 & 4,17 & 2,85 & 1,53 \\
\hline
\end{tabular}


Tabela 17. Famílias de nematóides e abundâncias absolutas ( $\mathrm{A}$, números de indivíduos por $200 \mathrm{ml}$ de solo), abundâncias relativas (Ar\%), freqüências absolutas (F\%), freqüências relativas ( $\mathrm{Fr} \%$ ), valores de proeminência absolutos (VP) e valores de proeminência relativos (VP\%) de área de goiabal (médias de 10 amostras de solo coletadas em fevereiro de 2000).

\begin{tabular}{lcccccc}
\hline Famílias & $\mathrm{A}$ & $\mathrm{Ar} \%$ & $\mathrm{~F} \%$ & Fr\% & VP & VP\% \\
\hline Hoplolaimidae & 153,40 & 35,45 & 100 & 8,47 & 1534,00 & 40,26 \\
Longidoridae & 47,10 & 10,88 & 60 & 5,08 & 364,83 & 9,57 \\
Cephalobidae & 41,40 & 9,57 & 90 & 7,63 & 392,75 & 10,31 \\
Qudsianematidae & 34,60 & 8,00 & 100 & 8,47 & 346,00 & 9,08 \\
Diphtherophoridae & 25,80 & 5,96 & 80 & 6,78 & 230,76 & 6,05 \\
Rhabditidae & 24,00 & 5,55 & 90 & 7,63 & 227,68 & 5,97 \\
Criconematidae & 21,00 & 4,85 & 30 & 2,54 & 115,02 & 3,02 \\
Mydonomidae & 15,50 & 3,58 & 70 & 5,93 & 129,68 & 3,40 \\
Trichodoridae & 15,50 & 3,58 & 70 & 5,93 & 129,68 & 3,40 \\
Tylenchidae & 9,50 & 2,19 & 50 & 4,24 & 67,17 & 1,76 \\
Belondiridae & 7,50 & 1,73 & 50 & 4,24 & 53,03 & 1,39 \\
Dorylaimidae & 7,10 & 1,64 & 50 & 4,24 & 50,20 & 1,32 \\
Alaimidae & 5,00 & 1,15 & 30 & 2,54 & 27,39 & 0,72 \\
Nordiidae & 4,90 & 1,13 & 30 & 2,54 & 26,84 & 0,70 \\
Actinolaimidae & 4,60 & 1,06 & 50 & 4,24 & 32,53 & 0,85 \\
Carcharolaimidae & 4,50 & 1,04 & 40 & 3,40 & 28,46 & 0,75 \\
Aphelenchidae & 2,80 & 0,65 & 40 & 3,40 & 17,71 & 0,46 \\
Leptonchidae & 1,50 & 0,35 & 30 & 2,54 & 8,21 & 0,21 \\
Plectidae & 1,40 & 0,32 & 20 & 1,69 & 6,26 & 0,16 \\
Monhysteridae & 1,20 & 0,28 & 20 & 1,69 & 5,37 & 0,14 \\
Tylencholaimidae & 1,10 & 0,25 & 20 & 1,69 & 4,92 & 0,13 \\
Mononchidae & 1,00 & 0,23 & 10 & 0,85 & 3,16 & 0,08 \\
Aporcelaimidae & 0,80 & 0,18 & 10 & 0,85 & 2,53 & 0,07 \\
Anguinidae & 0,50 & 0,11 & 10 & 0,85 & 1,58 & 0,04 \\
& & & & & & \\
& & 50 &
\end{tabular}


Tabela 17. Famílias de nematóides e abundâncias absolutas (A, números de indivíduos por $200 \mathrm{ml}$ de solo), abundâncias relativas (Ar\%), freqüências absolutas (F\%), freqüências relativas (Fr\%), valores de proeminência absolutos (VP) e valores de proeminência relativos (VP\%) de área de goiabal (médias de 10 amostras de solo coletadas em fevereiro de 2000).

\begin{tabular}{lcccccc}
\hline Famílias & A & Ar\% & F\% & Fr\% & VP & VP\% \\
\hline Cyatholaimidae & 0,50 & 0,11 & 10 & 0,85 & 1,58 & 0,04 \\
Nygolaimidae & 0,50 & 0,11 & 10 & 0,85 & 1,58 & 0,04 \\
Panagrolaimidae & 0,50 & 0,11 & 10 & 0,85 & 1,58 & 0,04 \\
\hline
\end{tabular}

Tabela 18. Gêneros de nematóides e abundâncias absolutas $(\mathrm{A}$, números de indivíduos por $200 \mathrm{ml}$ de solo), abundâncias relativas (Ar\%), freqüências absolutas ( $F \%$ ), freqüências relativas (Fr\%), valores de proeminência absolutos (VP) e valores de proeminência relativos (VP\%) de área de goiabal (médias de 10 amostras de solo coletadas em fevereiro de 2000).

\begin{tabular}{lcccccc}
\hline Gêneros & $\mathrm{A}$ & $\mathrm{Ar} \%$ & $\mathrm{~F} \%$ & $\mathrm{Fr} \%$ & $\mathrm{VP}$ & $\mathrm{VP} \%$ \\
\hline Helicotylenchus & 153,40 & 35,45 & 100 & 7,14 & 1534,00 & 45,38 \\
Xiphinema & 47,10 & 10,88 & 60 & 4,28 & 364,83 & 56,90 \\
Acrobeles & 30,40 & 7,02 & 90 & 6,43 & 288,40 & 44,98 \\
Diphtherophora & 25,80 & 5,96 & 80 & 5,71 & 230,76 & 35,99 \\
Hemicycliophora & 20,70 & 4,78 & 20 & 1,43 & 92,57 & 14,44 \\
Paratrichodorus & 15,50 & 3,58 & 70 & 5,00 & 129,68 & 20,23 \\
Dorylaimoides & 15,20 & 3,51 & 60 & 4,38 & 117,74 & 18,36 \\
Rhabditis & 11,90 & 2,75 & 80 & 5,71 & 106,44 & 16,60 \\
Discolaimium & 11,20 & 2,59 & 70 & 5,00 & 93,70 & 14,61 \\
Labronema & 7,50 & 1,73 & 90 & 6,57 & 71,15 & 11,10 \\
Opisthodorylaimus & 5,90 & 1,36 & 50 & 3,57 & 41,72 & 6,51 \\
Dorylaimellus & 5,80 & 1,34 & 30 & 2,14 & 31,77 & 4,95 \\
Acrobeloides & 5,60 & 1,29 & 60 & 4,28 & 43,38 & 6,76 \\
Alaimus & 5,00 & 1,15 & 30 & 2,14 & 27,39 & 4,27 \\
Paractinolaimus & 4,60 & 1,06 & 10 & 0,71 & 14,55 & 2,27
\end{tabular}


Tabela 18. Gêneros de nematóides e abundâncias absolutas ( $\mathrm{A}$, números de indivíduos por $200 \mathrm{ml}$ de solo), abundâncias relativas (Ar\%), freqüências absolutas (F\%), freqüências relativas (Fr\%), valores de proeminência absolutos (VP) e valores de proeminência relativos (VP\%) de área de goiabal (médias de 10 amostras de solo coletadas em fevereiro de 2000).

\begin{tabular}{|c|c|c|c|c|c|c|}
\hline Gêneros & A & Ar\% & $\mathrm{F} \%$ & Fr\% & VP & VP\% \\
\hline Discolaimoides & 4,80 & 1,11 & 40 & 2,86 & 30,36 & 4,73 \\
\hline Oriverutus & 3,70 & 0,85 & 30 & 2,14 & 20,27 & 3,16 \\
\hline Carcharolaimus & 3,60 & 0,83 & 40 & 2,86 & 22,77 & 3,55 \\
\hline Eudorylaimus & 3,50 & 0,81 & 60 & 4,38 & 27,11 & 4,23 \\
\hline Eucephalobus & 2,90 & 0,67 & 30 & 2,14 & 15,88 & 2,48 \\
\hline Aphelenchus & 2,80 & 0,65 & 40 & 2,86 & 17,71 & 2,76 \\
\hline Discolaimus & 2,30 & 0,53 & 20 & 1,43 & 10,28 & 1,60 \\
\hline Aporcelaimellus & 2,20 & 0,51 & 30 & 2,14 & 12,05 & 1,88 \\
\hline Cephalobus & 2,20 & 0,51 & 20 & 1,43 & 9,84 & 1,53 \\
\hline Microdorylaimus & 2,20 & 0,51 & 20 & 1,43 & 9,84 & 1,53 \\
\hline Mesodorylaimus & 2,10 & 0,48 & 30 & 2,14 & 11,50 & 1,79 \\
\hline Prismatolaimus & 1,20 & 0,28 & 20 & 1,43 & 5,37 & 0,84 \\
\hline Leptonchus & 1,00 & 0,23 & 20 & 1,43 & 4,47 & 0,70 \\
\hline Mononchus & 1,00 & 0,23 & 10 & 0,71 & 3,16 & 0,49 \\
\hline Ditylenchus & 0,50 & 0,11 & 10 & 0,71 & 1,58 & 0,25 \\
\hline Enchodelus & 0,50 & 0,11 & 10 & 0,71 & 1,58 & 0,25 \\
\hline Odontolaimus & 0,50 & 0,11 & 10 & 0,71 & 1,58 & 0,25 \\
\hline Axonchium & 0,30 & 0,07 & 10 & 0,71 & 0,95 & 0,15 \\
\hline Chronogaster & 0,30 & 0,07 & 10 & 0,71 & 0,95 & 0,15 \\
\hline Chiloplacus & 0,30 & 0,07 & 10 & 0,71 & 0,95 & 0,15 \\
\hline Chitwoodius & 0,30 & 0,07 & 10 & 0,71 & 0,95 & 0,15 \\
\hline Criconemella & 0,30 & 0,07 & 10 & 0,71 & 0,95 & 0,15 \\
\hline Plectus & 0,30 & 0,07 & 10 & 0,71 & 0,95 & 0,15 \\
\hline
\end{tabular}


Tabela 19. Famílias de nematóides e abundâncias absolutas (A, números de indivíduos por $5 \mathrm{~g}$ de raízes), abundâncias relativas ( $\mathrm{Ar} \%)$, freqüências absolutas ( $\mathrm{F} \%)$, freqüências relativas (Fr\%), valores de proeminência absolutos (VP) e valores de proeminência relativos (VP\%) de área de goiabal (médias de 10 amostras de raízes coletadas em fevereiro de 2000).

\begin{tabular}{lcccccc}
\hline Famílias & A & Ar\% & F\% & Fr\% & VP & VP\% \\
\hline Pratylenchidae & 24,00 & 40,13 & 90 & 37,50 & 227,68 & 42,56 \\
Hoplolaimidae & 22,50 & 37,62 & 70 & 29,17 & 188,25 & 35,19 \\
Tylenchidae & 13,30 & 22,24 & 80 & 33,33 & 118,96 & 22,24 \\
\hline
\end{tabular}

Tabela 20. Gêneros de nematóides e abundâncias absolutas (A, números de indivíduos por $5 \mathrm{~g}$ de raízes), abundâncias relativas ( $\mathrm{Ar} \%)$, freqüências absolutas $(\mathrm{F} \%)$, freqüências relativas (Fr\%), valores de proeminência absolutos (VP) e valores de proeminência relativos (VP\%) de área de goiabal (médias de 10 amostras de raízes coletadas em fevereiro de 2000).

\begin{tabular}{lcccccc}
\hline Gêneros & A & Ar\% & F\% & Fr\% & VP & VP\% \\
\hline Pratylenchus & 24,00 & 40,13 & 90 & 56,25 & 227,68 & 54,74 \\
Helicotylenchus & 22,50 & 37,62 & 70 & 43,75 & 188,25 & 45,26 \\
\hline
\end{tabular}

Tabela 21. Famílias de nematóides e abundâncias absolutas (A, números de indivíduos por $200 \mathrm{ml}$ de solo), abundâncias relativas (Ar\%), freqüências absolutas (F\%), freqüências relativas (Fr\%), valores de proeminência absolutos (VP) e valores de proeminência relativos (VP\%) de área de milharal (médias de 10 amostras de solo coletadas em fevereiro de 2000).

\begin{tabular}{lcccccc}
\hline Famílias & $\mathrm{A}$ & $\mathrm{Ar} \%$ & $\mathrm{~F} \%$ & $\mathrm{Fr} \%$ & $\mathrm{VP}$ & $\mathrm{VP \%}$ \\
\hline Hoplolaimidae & 98,90 & 32,52 & 100 & 8,33 & 989,00 & 35,20 \\
Cephalobidae & 48,00 & 15,78 & 100 & 8,33 & 480,00 & 17,08 \\
Tylencholaimidae & 27,30 & 8,98 & 80 & 6,67 & 244,18 & 8,69 \\
Tylenchidae & 21,80 & 7,17 & 90 & 7,50 & 206,81 & 7,36 \\
Trichodoridae & 21,20 & 6,97 & 90 & 7,50 & 201,12 & 7,16 \\
Dorylaimidae & 20,10 & 6,61 & 100 & 8,33 & 201,00 & 7,15
\end{tabular}


Tabela 21. Famílias de nematóides e abundâncias absolutas (A, números de indivíduos por $200 \mathrm{ml}$ de solo), abundâncias relativas (Ar\%), freqüências absolutas (F\%), freqüências relativas ( $\mathrm{Fr} \%)$, valores de proeminência absolutos (VP) e valores de proeminência relativos (VP\%) de área de milharal (médias de 10 amostras de solo coletadas em fevereiro de 2000).

\begin{tabular}{lcccccc}
\hline Famílias & $\mathrm{A}$ & $\mathrm{Ar} \%$ & $\mathrm{~F} \%$ & $\mathrm{Fr} \%$ & $\mathrm{VP}$ & $\mathrm{VP} \%$ \\
\hline Diphtherophoridae & 13,20 & 4,34 & 80 & 6,67 & 118,02 & 4,20 \\
Rhabditidae & 10,40 & 3,42 & 80 & 6,67 & 93,02 & 3,31 \\
Anguinidae & 9,10 & 2,99 & 40 & 3,33 & 57,55 & 2,05 \\
Aphelenchidae & 8,10 & 2,66 & 40 & 3,33 & 51,23 & 1,82 \\
Monhysteridae & 5,40 & 1,77 & 50 & 4,17 & 38,18 & 1,36 \\
Aphelenchoididae & 4,80 & 1,58 & 60 & 5,00 & 37,18 & 1,32 \\
Plectidae & 2,80 & 0,92 & 50 & 4,17 & 19,80 & 0,70 \\
Qudsianematidae & 2,80 & 0,92 & 60 & 5,00 & 21,69 & 0,74 \\
Mononchidae & 2,70 & 0,89 & 30 & 2,50 & 14,79 & 0,53 \\
Mylonchulidae & 2,40 & 0,79 & 30 & 2,50 & 13,14 & 0,47 \\
Panagrolaimidae & 1,90 & 0,62 & 40 & 3,33 & 12,02 & 0,43 \\
Aporcelaimidae & 0,80 & 0,26 & 20 & 1,67 & 3,58 & 0,13 \\
Actinolaimidae & 0,40 & 0,13 & 10 & 0,83 & 1,26 & 0,04 \\
Ironidae & 0,40 & 0,13 & 10 & 0,83 & 1,26 & 0,04 \\
Leptonchidae & 0,40 & 0,13 & 10 & 0,83 & 1,26 & 0,04 \\
Paraphelenchidae & 0,40 & 0,13 & 10 & 0,83 & 1,26 & 0,04 \\
Belondiridae & 0,30 & 0,10 & 10 & 0,83 & 0,95 & 0,03 \\
Nygolaimellidae & 0,30 & 0,10 & 10 & 0,83 & 0,95 & 0,03 \\
Cyatholaimidae & 0,20 & 0,06 & 10 & 0,83 & 0,63 & 0,02 \\
\hline
\end{tabular}


Tabela 22. Gêneros de nematóides e abundâncias absolutas (A, números de indivíduos por $200 \mathrm{ml}$ de solo), abundâncias relativas (Ar\%), freqüências absolutas (F\%), frequêencias relativas ( $\mathrm{Fr} \%)$, valores de proeminência absolutos (VP) e valores de proeminência relativos (VP\%) de área de milharal (médias de 10 amostras de solo coletadas em fevereiro de 2000).

\begin{tabular}{lcccccc}
\hline Gêneros & $\mathrm{A}$ & $\mathrm{Ar} \%$ & $\mathrm{~F} \%$ & $\mathrm{Fr} \%$ & $\mathrm{VP}$ & $\mathrm{VP} \%$ \\
\hline Helicotylenchus & 98,90 & 32,52 & 100 & 7,63 & 989,00 & 41,55 \\
Chitwoodius & 27,30 & 8,98 & 80 & 6,11 & 244,18 & 10,26 \\
Paratrichodorus & 21,20 & 6,97 & 90 & 6,87 & 201,12 & 8,45 \\
Acrobeles & 20,30 & 6,67 & 60 & 4,58 & 157,24 & 6,60 \\
Diphtherophora & 13,20 & 4,34 & 80 & 6,11 & 118,06 & 4,96 \\
Mesodorylaimus & 10,10 & 3,32 & 50 & 3,82 & 71,42 & 3,00 \\
Zeldia & 10,10 & 3,32 & 70 & 5,34 & 84,50 & 3,55 \\
Eucephalobus & 9,50 & 3,12 & 90 & 6,87 & 90,12 & 3,78 \\
Opisthodorylaimus & 9,30 & 3,06 & 80 & 6,11 & 83,18 & 3,49 \\
Ditylenchus & 9,10 & 2,99 & 40 & 3,05 & 57,55 & 2,42 \\
Aphelenchus & 8,90 & 2,93 & 50 & 3,82 & 62,93 & 2,64 \\
Cephalobus & 6,20 & 2,04 & 40 & 3,05 & 39,21 & 1,65 \\
Prismatolaimus & 5,40 & 1,77 & 50 & 3,82 & 38,18 & 1,60 \\
Rhabditis & 4,80 & 1,58 & 40 & 3,05 & 30,36 & 1,27 \\
Aphelenchoides & 4,00 & 1,31 & 40 & 3,05 & 25,30 & 1,06 \\
Plectus & 2,50 & 0,82 & 40 & 3,05 & 15,81 & 0,66 \\
Eudorylaimus & 2,20 & 0,72 & 60 & 4,58 & 17,04 & 0,71 \\
Prionchulus & 2,10 & 0,69 & 20 & 1,53 & 9,39 & 0,39 \\
Panagrolaimus & 1,90 & 0,62 & 40 & 3,05 & 12,02 & 0,50 \\
Sporonchulus & 1,80 & 0,59 & 20 & 1,53 & 8,05 & 0,34 \\
Mesorhabditis & 1,20 & 0,39 & 20 & 1,53 & 5,37 & 0,23 \\
Acrobeloides & 0,80 & 0,26 & 10 & 0,76 & 2,53 & 0,11 \\
Mylonchulus & 0,60 & 0,20 & 10 & 0,76 & 1,90 & 0,08 \\
Amphidorylaimus & 0,50 & 0,16 & 20 & 1,53 & 2,24 & 0,09
\end{tabular}


Tabela 22. Gêneros de nematóides e abundâncias absolutas ( $\mathrm{A}$, números de indivíduos por $200 \mathrm{ml}$ de solo), abundâncias relativas (Ar\%), freqüências absolutas (F\%), freqüências relativas $(\mathrm{Fr} \%)$, valores de proeminência absolutos (VP) e valores de proeminência relativos (VP\%) de área de milharal (médias de 10 amostras de solo coletadas em fevereiro de 2000).

\begin{tabular}{lcccccc}
\hline Gêneros & $\mathrm{A}$ & $\mathrm{Ar} \%$ & $\mathrm{~F} \%$ & $\mathrm{Fr} \%$ & $\mathrm{VP}$ & $\mathrm{VP} \%$ \\
\hline Chiloplacus & 0,40 & 0,13 & 10 & 0,76 & 1,26 & 0,05 \\
Iromus & 0,40 & 0,13 & 10 & 0,76 & 1,26 & 0,05 \\
Paractinolaimus & 0,40 & 0,13 & 10 & 0,76 & 1,26 & 0,05 \\
Paraphelenchus & 0,40 & 0,13 & 10 & 0,76 & 1,26 & 0,05 \\
Dorylaimellus & 0,30 & 0,10 & 10 & 0,76 & 1,26 & 0,05 \\
Nygolaimellus & 0,30 & 0,10 & 10 & 0,76 & 1,26 & 0,05 \\
Discolaimium & 0,20 & 0,06 & 10 & 0,76 & 1,26 & 0,05 \\
Discolaimoides & 0,20 & 0,06 & 10 & 0,76 & 1,26 & 0,05 \\
Discolaimus & 0,20 & 0,06 & 10 & 0,76 & 1,26 & 0,05 \\
Dorylaimus & 0,20 & 0,06 & 10 & 0,76 & 1,26 & 0,05 \\
Achromadora & 0,20 & 0,06 & 10 & 0,76 & 1,26 & 0,05 \\
\hline
\end{tabular}

Tabela 23. Famílias de nematóides e abundâncias absolutas (A, números de indivíduos por $5 \mathrm{~g}$ de raízes), abundâncias relativas (Ar\%), freqüências absolutas ( $\mathrm{F} \%)$, freqüências relativas (Fr\%), valores de proeminência absolutos (VP) e valores de proeminência relativos (VP\%) de área de milharal (médias de 10 amostras de raízes coletadas em fevereiro de 2000).

\begin{tabular}{lcccccc}
\hline Famílias & A & Ar\% & F\% & Fr\% & VP & VP\% \\
\hline Hoplolaimidae & 50,70 & 40,82 & 100 & 32,26 & 507,00 & 43,71 \\
Pratylenchidae & 44,70 & 35,99 & 90 & 29,03 & 424,06 & 36,56 \\
Aphelenchoididae & 19,50 & 15,70 & 70 & 22,58 & 163,15 & 14,06 \\
Tylenchidae & 9,30 & 7,49 & 50 & 16,13 & 65,76 & 5,67 \\
\hline
\end{tabular}


Tabela 24. Gêneros de nematóides e abundâncias absolutas (A, números de indivíduos por $5 \mathrm{~g}$ de raízes), abundâncias relativas (Ar\%), freqüências absolutas (F\%), freqüências relativas $(\mathrm{Fr} \%)$, valores de proeminência absolutos (VP) e valores de proeminência relativos (VP\%) de área de milharal (médias de 10 amostras de raízes coletadas em fevereiro de 2000).

\begin{tabular}{lcccccc}
\hline Gêneros & $\mathrm{A}$ & $\mathrm{Ar} \%$ & $\mathrm{~F} \%$ & $\mathrm{Fr} \%$ & $\mathrm{VP}$ & $\mathrm{VP} \%$ \\
\hline Helicotylenchus & 50,70 & 40,82 & 100 & 38,46 & 507,00 & 46,33 \\
Pratylenchus & 44,70 & 35,99 & 90 & 34,61 & 424,06 & 38,75 \\
Aphelenchoides & 19,50 & 15,70 & 70 & 26,92 & 163,15 & 14,91 \\
\hline
\end{tabular}




\section{REFERÊNCIAS BIBLIOGRÁFICAS}

AGRIOS, G.N. Plant diseases caused by nematodes. In: AGRIOS, G.N. Plant pathology. San Diego: Academic Press, 1997. cap.15, p.565-597.

AL BANNA, L.; GARDNER, S.L. Nematode diversity of native species of Vitis in California. Canadian Journal of Zoology, v.74, n.6, p.971-982, 1996.

ALTIERI, M.A. The ecological role of biodiversity in agroecosystems. Agriculture, Ecosystems and Environment, v.74, n.1, p.19-31, 1999.

ANDERSON, R.R.; COLEMAN, D.C.; COLE, C.V.; ELLIOTT, E.T. Effect of the nematodes Acrobeloides lheritieri on substrate utilization and nitrogen and phosphorus mineralization in soil. Ecology, v.62, n.3, p.549-555, 1981.

ANDRÁSSY, I. Evolution as a basis for the systematization of nematodes. London: Pitman, 1976. 288p.

ANDRÁSSY, I. A taxonomic review of the suborder Rhabditina (Nematoda: Secernentia). Paris: ORSTOM, 1983. 241p.

ARMENDÁRIZ, L.; ARPIN, P. Nematodes and their relationship to forest dynamics: I. Species and trophic groups. Biology and Fertility of Soils, v.23, n.4, p.405-413, 1996. 
ARMENDÁRIZ, I.; HERNÁNDEZ, M. Analisi del popolamento nematologico in una pineta a Pinus halepensis in Navarra (Spagna). Nematologia Mediterranea, v.23, suppl., p.57-59, 1995.

BARDGETT, R.D.; CHAN, K.F. Experimental evidence that soil fauna enhance nutrient mineralization and plant nutrient uptake in montane grassland ecosystems. Soil Biology and Biochemistry, v.31, n.7, p.1007-1014, 1999.

BARKER, K.R. Sampling nematode communities. In: BARKER, K.R.; CARTER, C.C.; SASSER, J.N. (Ed.). An advanced treatise ou Meloidogyne. II. Methodology. Raleigh: North Carolina State University; USAID, 1985. p.3-17.

BERNARD, E.C. Soil nematode biodiversity. Biology and Fertility of Soils, v.14, n.2, p.99-103, 1992.

BLOEMERS, G.F.; HODDA, M.; LAMBSHEAD, P.J.D.; LAWTON, J.H.; WANLESS, F.R. The effects of forest disturbance on diversity of tropical soil nematodes. Oecologia, v.111, n.4, p.575-582, 1997.

BONGERS, T. The maturity index: an ecological measure of environmental disturbance based on nematode species composition. Oecologia, v.83, n.1, p.14-19, 1990.

BONGERS, T.; BONGERS, M. Functional diversity of nematodes. Applied Soil Ecology, v.10, n.3, p.239-251, 1998.

BOUWMAN, L.A.; ZWART, K.B. The ecology of bacterivorous protozoans and nematodes in arable soil. Agriculture, Ecosystems and Environment, v.51, n.2, p.145-160, 1994. 
BRAY, J.R.; CURTIS, J.T. An ordination of the upland forest communities of Southern Wisconsin. Ecological Monographs, v.27, p.325-349, 1957.

BREWER, R. Community and ecosystem ecology. In: BREWER, R. The science of ecology. Ft Worth: Saunders College/Harcourt Brace College, 1994. p.263-306.

BULLUCK III, L.R.; BARKER, K.R.; RISTAINO, J.B. Influences of organic and synthetic soil fertility amendments on nematode rophic groups and community dynamics under tomatoes. Applied Soil Ecology, v.21, n.3, p.233-250, 2002.

CARES, J.H.; HUANG, S.P. Nematode fauna in natural and cultivated cerrados of Central Brazil. Fitopatologia Brasileira, v.16, n.3, p.199-209, 1991.

CARES, J.E.; HUANG, S.P. Taxonomia atual de fitonematóides: chave sistemática simplificada para gêneros - Parte I. Revisão Anual de Patologia de Plantas, v.8, p.185-223, 2000.

CARES, J.E.; HUANG, S.P. Taxonomia de fitonematóides: chave sistemática simplificada para gêneros - Parte II. Revisão Anual de Patologia de Plantas, v.9, p.177-235, 2001

CAVENESS, F.E. Changes in plant parasitic nematode populations on newly cleared land. Nematropica, v.2, n. 1, p.1-2, 1972.

CHEN, J.; FERRIS, H. The effects of nematode grazing on nitrogen mineralization during fungal decomposition of organic matter. Soil Biology and Biochemistry, v.31, n.9, p.1265-1279, 1999.

COLEMAN, D.C.; CROSSLEY, D.A., JR. Fundamentals of soil ecology. San Diego: Academic Press, 1996. 205p. 
COLEMAN, D.C.; EDWARDS, A.L.; BELSKY, A.J.; MWONGA, S. The distribution and abundance of soil nematodes in East African savannas. Biology and Fertility of Soils, v.12. n.1, p.67-72, 1991.

COOLEN, W.A.; D'HERDE, C.J. A method for the quantitative extraction of nematodes from plant tissue. Ghent: State Nematology and Entomology Research Station, 1972. 77p.

COUTINHO, L.M. O conceito de cerrado. Revista Brasileira de Botânica, v.1, p.17-23, 1978.

COYNE, D.L.; SMITH, M.; PLOWRIGHT, R. Plant parasitic nematode populations on upland and hydromorphic rice in Côte d'Ivoire: relationship with moisture availability and crop development on a valley slope. Agriculture, Ecosystems and Environment, v.84, n.1, p.31-43, 2001.

COYNE, D.L.; THIO, B.; PLOWRIGHT, R.A.; HUNT, D.J. Observations on the community dynamics of plant parasitic nematodes of rice in Côte d'Ivoire. Nematology, v.1, n.4, p.433-441, 1999.

CROLL, N.A.; MATTHEWS, B.E. Biology of nematodes. Glasgow: Blackie, 1977. $201 \mathrm{p}$.

DECRAEMER, W. The family Trichodoridae: stubby root and virus vector nematodes. Dordrecht: Kluwer Academic, 1995. 360p.

DE GOEDE, R.G.M. Effects of sod-cutting on the nematode community of a secondary forest of Pimus sylvestris L. Biology and Fertility of Soils, v.22, n.3, p.227-236, 1996. 
DE RUITER, P.C.; MOORE, J.C.,ZWART, K.B.; BOUWMAN, L.A.;HASSINK, J.; BLOEM, J.; DE VOS, J.A.; MARINISSEN, J.C.Y.; BIDDEN, W.A.M.; LEBBINK, G.; GRUSSAARD, L. Simulation of nitrogen mineralization in the below-ground food webs of two winter wheat fields. Journal of Applied Ecology, v.30, n.1, p.95-106, 1993.

DORAN, J.W.; ZEISS, M.R. Soil health and sustainability: managing the biotic component of soil quality. Applied Soil Ecology, v.15, n.1, p.3-11, 2000.

DROPKIN, V.H. Population dynamics. In: DROPKIN, V.H. Introduction to plant nematology. New York: John Wiley, 1980. cap.11, p.242-256.

EHRENFELD, D. Why put a value on biodiversity? In: WIILSON, E. O.; PETER, F. M. (Ed.). Biodiversity. Washington: National Academy Press, p.212-216, 1988.

EHRLICH, P.R.; MOONEY, H.A. Extinction, substitution, and ecosystem services. Bioscience, v.33, n.4, p.248-253, 1983.

FERRAZ, L.C.C.B.; MONTEIRO, A.R. Nematóides. In: BERGAMIN FILHO, A.; KIMATI, H.; AMORIM, L. (Ed.). Manual de fitopatologia. v.1, Princípios e conceitos. São Paulo: Ceres, 1995. cap.8, p.168-201.

FERRAZ, L.C.C.B.; OLIVEIRA, J.C. Água de irrigação como agente disseminador de nematóides em viveiros de mudas. Revista de Agricultura, v.55, n.1/2, p.13-19, 1980.

FERRIS, H.; VENETTE, R.C.; VAN DER MEULEN, H.R.; LAU, S.S. Nitrogen mineralization by bacterial-feeding nematodes: verification and measurement. Plant and Soil, v.203, n.2, p.159-171, 1998. 
FERRIS, V.R.; FERRIS, J.M. Inter-relationships between nematode and plant communities in agricultural ecosystems. Agro-ecosystems, v.1, n.4, p.275-299, 1974.

FERRIS, V.R.; FERRIS, J.M.; BERNARD, R.L.; PROBST, A.H. Community structure of plant parasitic nematodes related to soil types in Illinois and Indiana soybean fields. Journal of Nematology, v.3, n.4, p.399-408, 1971.

FORTUNER, R. Methods for collection and preparation of nematodes. Part 1. Field sampling and preparation of nematodes for optic microscopy. In: NICKLE, W.R. (Ed.). Manual of agricultural nematology. New York: Marcel Dekker, 1991. p.75-87.

FRECKMAN, D.W. Bacterivorous nematodes and organic-matter decomposition. Agriculture, Ecosystems and Environment, v.24, n.1/3, p.195-217, 1988.

FRECKMAN, D.W.; CASWELL, E.P. The ecology of nematodes in agroecosystems. Annual Review of Phytopathology, v.23, p.275-296, 1985.

FRECKMAN, D.W.; ETTEMA, C.H. Assessing nematode communities in agroecosystems of varying human intervention. Agriculture, Ecosystems and Environment, v.45, n.3/4, p.239-261, 1993.

FRECKMAN, D.W.; MANKAU, R.; FERRIS, H. Nematode community structure in desert soils: nematode recovery. Journal of Nematology, v.7, n.4, p.343-346, 1975.

GOMES, G.S. Biodiversidade e características da estrutura de comunidades de nematóides em campos de soja (Glycine max Merr.) no Distrito Federal. Brasília, 1996. 65p. Dissertação (Mestrado) - Universidade de Brasília 
GOODELL, P.B. Soil sampling and processing for detection and quantification of nematode populations for ecological studies. In: FRECKMAN, D.W. (Ed.). Nematodes in soil ecosystems. Austin: University of Texas Press, p. 178-198, 1982.

GOODEY, J.B. Soil and freshwater nematodes. London: Methuen, 1963. 544p.

GRIFFITHS, B.S.; CAUL, S. Migration of bacterial-feeding nematodes, but not protozoa, to decomposing grass residues. Biology and Fertility of Soils, v.15, n.3, p.201-207, 1993.

HÁNEL, L. Secondary successional stages of soil nematodes in cambisols of South Bohemia. Nematologica, v.41, n.2, p.197-218, 1995.

HAWKSWORTH, D.L.; RITCHIE, J.M. Biodiversity and biosystematic priorities: microorganisms and invertebrates. Wallingford: CAB International, 1993. 120p.

HERRICK, J.E. Soil quality: an indicator of sustainable land management? Applied Soil Ecology, v. 15, n.1, p.75-83, 2000.

HEYNS, J. A guide to the plant and soil nematodes of South Africa. Cape Town: A. A. Balkema, 1971. 232p.

HIBERT, D.W.; SWIFT, D.M.; DETLING, D.M.; DYER, M.I. Relative growth rates and the grazing optimization hypothesis. Oecologia, v.51, n.1, p.14-18, 1981.

HYVÖNEN, R.; PERSSON, T. Effects of acidification and liming on feeding groups of nematodes in coniferous forest soils. Biology and Fertility of Soils, v.9, n.3, p.205-210, 1990. 
HODDA, M.; WANLESS, F.R. Nematodes from an english chalk grassland: species distributions. Nematologica, v.40, n.1, p.116-132, 1994.

HOOPER, D.J. Handling, fixing, staining and moulting nematodes. In: SOUTHEY, J.F. (Ed.). Laboratory methods for work with plant and soil nematodes. London: Ministry of Agriculture, Fisheries and Food, 1986. p.59-80.

HUANG, S.P.; CARES, J.H. Community composition of plant-parasitic nematodes in native and cultivated cerrados of Central Brazil. Journal of Nematology, v.27, n.2, p.237-243, 1995.

HUANG, S.P.; FREIRE, H.C.A.; CARES, J.E. Grupos composicionais e tróficos dos nematóides associados à sucupira branca (Pterodon pubescens) em cerrado nativo. Fitopatologia Brasileira, v.21, n.2, p.156-160, 1996.

HUNT, D.J. Aphelenchida, Longidoridae and Trichodoridae: their systematics and bionomics. Wallingford: CAB International, 1993. 352p.

HUNTER JUNIOR, M.L. Fundamentals of conservation biology. Massachusetts: Blackwell Science, 1996. 482p.

HUNTER JUNIOR, M.L. Biological diversity. In: HUNTER JUNIOR, M.L. (Ed.). Maintaining biodiversity in forest ecosystems. London: Cambridge University Press, 1999. cap.1, p.3-21.

IVEZIC, M.; RASPUDIC, E.; BRMEZ, M. Structure of nematode communities in different agroecosystems in Croatia. Helminthologia, v.37, n.3, p. 165-169, 2000.

JAIRAJPURI, M.S.; AHMAD, W. Dorylaimida: free-living, predaceous and plant-parasitic nematodes. Leiden: E.J. Brill, 1992. 458p. 
JAIRAJPURI, M.S.; KHAN, W.U. Predatory nematodes (Mononchida). New Delhi: Associated Publ., 1981. 131p.

JENKINS, W.R. A rapid centrifugal-flotation technique for separating nematodes from soil. Plant Disease Reporter, v.48, n.9, p.692, 1964.

JOHNSON, S.R.; FERRIS, V.R.; FERRIS, J.M. Nematode community structure in forest woodlots. I. Relationships based on similarity coefficients of nematode species. Journal of Nematology, v.4, n.3, p.175-183, 1972.

JOHNSON, S.R.; FERRIS, J.M.; VERRIS, V.R. Nematode community structure in forest woodlots. II. Ordination of nematode communities. Journal of Nematology, v.5, n.2, p.95-107, 1973.

JOHNSON, S.R.; FERRIS, J.M.; FERRIS, V.R. Nematode community structure of forest woodlots: III. Ordinations of taxonomic groups and biomass. Journal of Nematology, v.6, n.3, p.118-126, 1974.

JONGMAN, R.H.G.; TER BRAAK, C.J.F.; VAN TONGEREN, O.F.R. (Ed.). Data analysis in community and landscape ecology. Cambridge: Cambridge University Press, 1995. 299p.

JUSINO-ATRESINO, R.; PHILLIPS JUNIOR, S.A. Impact of red imported fire ants on the ant fauna of Central Texas. In: WILLIAMS, D. (Ed.). Exotic ants. Boulder: Westview Press, 1994. p.259-268.

КANDJ, S.T.; OGOL, C.K.P.O.; ALBRECHT, A. Diversity of plant-parasitic nematodes and their relationships with some soil physico-chemical characteristics in improved fallows in western Kenya. Applied Soil Ecology, v.18, n.2, p.143-157, 2001. 
KANNO, S.S. Curso diário e sazonal das trocas gasosas e potencial hídrico foliar em três espécies lenhosas do cerrado: Anacardium nanum St. Hill, Andira humilis Marth ex. Benth e Eriotheca gracilipes (K. Schum) A. Robins. São Carlos, 1993. 100p. Dissertação (Mestrado) - Universidade Federal de São Carlos.

KIMPINSKY, J.; WELCH, H.E. The ecology of nematodes in Manitoba soils. Nematologica, v.17, n.2, p.308-318, 1971.

KIRJANOVA, E.S.; KRALL, E.I. Parasitic nematodes of plants and their control measures. New Delhi: Indian National Scientific Documentation Centre, 1977. $913 p$.

KRALL, E.L. Root parasitic nematodes: family Hoplolaimidae. Leiden: E.J. Brill, 1990. 580p.

KREBS, C.J. Ecological methodology. New York: Harper Collins, 1989. 654p.

KREBS, C.J. Ecology: the experimental analysis of distribution and abundance. New York: Harper Collins College, 1994. 80lp.

LAAKSO, J.; SETALA, H. Population and ecosystem-level effects of predation on microbial feeding nematodes. Oecologia, v.120, n.2, p.279-286, 1999.

LAL, A.; SANWAL, K.C.; MATHUR, V.K. Changes in the nematode population of undisturbed land with the introduction of land development practices and cropping sequences. Indian Journal of Nematology, v.13, n.2, p.133-140, 1983.

LENZ, R.; EISENBEIS, G. Short-term effects of different tillage in a sustainable farming system on nematode community structure. Biology and Fertility of Soils, v.31, n.3/4, p.237-244, 2000. 
LIANG, W.; LAVIAN, I.; STEINBERGER, Y. Dynamics of nematode community composition in a potato field. Pedobiologia, v.43, n.5, p.459-469, 1999.

LIANG, W.; MOURATOV, S.; PINHASI-ADIV, Y.; AVIGAD, P.; STEINBERGER, Y. Seasonal variation in the nematode communities associated with two halophytes in a desert ecosystem. Pedobiologia, v.46, n.1, p.63-74, 2002.

LORANDI, R. Caracterização dos solos das áreas urbana e suburbana de São Carlos (SP) e suas aplicações. Piracicaba, 1985. 181p. Tese (Doutorado) - Escola Superior de Agricultura "Luiz de Queiroz", Universidade de São Paulo.

LORDELLO, L.G.E. Contribuição para o conhecimento dos nematóides brasileiros da família Dorylaimidae (Classe: Adenophorea). Piracicaba, 1965. 68p. Tese (Livre-Docência) - Escola Superior de Agricultura "Luiz de Queiroz", Universidade de São Paulo.

LUDWIG, J.A.; REYNOLDS, J.F. Statistical ecology: a primer on methods and computing. New York: John Wiley, 1988. 337p.

MACGUIDWIN, A.E.; LAYNE, T.L. Response of nematode communities to sudangrass and sorghum-sudangrass hybrids grown as green manure crops. Journal of Nematology, v.27, n.4S, p.609-616, 1995.

MAGGENTI, A. General nematology. New York: Springer Verlag, 1981. 372p.

MAGGENTI, A.R. Nemata: higher classification. In: NICKLE, W.P. (Ed.). Manual of agricultural nematology. New York: Marcel Dekker, 1991. p.147-187. 
MAGGENTI, A.R.; LUC, M.; RASKI, D.J.; FORTUNER, R.; GERAERT, E. A reappraisal of Tylenchina (Nemata). 2. Classification of the suborder Tylenchina (Nemata: Diplogasteria). Revue de Nématologie, v. 10, n.2, p. 135-142, 1987.

MAGURRAN, A.E. Ecological diversity and its measurement. London: Croom Helm, 1988. 179p.

MATTOS, J.K.A. Caracterização das comunidades de nematóides em oito sistemas de uso da terra nos cerrados do Brasil Central. Brasília, 1999. 113p. Tese (Doutorado) - Universidade de Brasília.

MAY, W.F.; MULLIN, P.G. Plant-parasitic nematodes: a pictorial key to genera. New York: Cornell University Press, 1996. 277p.

MCSORLEY, R. Short-term effects of fire on the nematode community in a pine forest. Pedobiologia, v.37, n.1, p.39-48, 1993.

MCSORLEY, R. Relationship of crop and rainfall to soil nematode community structure in perennial agroecosystems. Applied Soil Ecology, v.6, n.2, p.147-159, 1997.

MIKOLA, J. Effect of microbivore species composition and basal resource enrichment on trophic-level biomasses in an experimental microbial-based soil food web. Oecologia, v.117, n.3, p.396-403, 1998.

MIKOLA, J.; SETALA, H. No evidence of trophic cascades in an experimental microbial-based soil food web. Ecology, v.79, n. 1, p.153-164, 1998. 
MISHRA, C.C.; DASH, M.C. Distribution and population dynamics of nematodes in a rice field and pasture in India. Journal of Nematology, v.13, n.4, p.538-543, 1981.

MISHRA, C.C.; MITCHELL, M.J. Nematode populations in Adirondack forest soils and ther potential role in sulfur cycling. Pedobiologia, v.30, n.4, p.277-283, 1987.

MONTEIRO, A.R. Dorylaimoidea de cafezais paulistas (Nemata, Dorylaimida). Piracicaba, 1970. 137p. Tese (Doutorado) - Escola Superior de Agricultura "Luiz de Queiroz", Universidade de São Paulo.

MUKHERJEE, B.; DASGUPTA, M.K. Community analyses of plant-parasitic nematodes in tea plantations of West Bengal, India. Nematologia Mediterranea, v.10, n.1, p.1-7, 1982.

MUKHERJEE, B.; DASGUPTA, M.K. Community analyses of nematodes associated with banana plantations in the hooghly district, West Bengal, India. Nematologia Mediterranea, v.11, n.1, p.43-48, 1983.

NEHER, D.A. Nematode communities in organically and conventionally managed agricultural soils. Journal of Nematology, v.31, n.2, p.142-154, 1999.

NEHER, D.A. Role of nematodes in soil health and their use as indicators. Journal of Nematology, v.33, n.4, p.161-168, 2001.

NEHER, D.A.; OLSON, R.K. Nematode communities in soils of four farm cropping management systems. Pedobiologia, v.43, n.5, p.430-438, 1999.

NEHER, D.A.; EASTERLING, K.N.; FISCUS, D.; CAMPBELL, C.L. Comparison of nematode communities in agricultural soils of North Carolina and Nebraska. Ecological Applications, v.8, n.1, p.213-223, 1998. 
NEHER, D.A.; PECK, S.L.; RAWLINGS, J.O.; CAMPBELL, C.L. Measures of nematode community structure and sources of variability among and within agricultural fields. Plant and Soil, v.170, n.1, p.167-181, 1995.

NIBLACK, T.L. Applications of nematode community structure research to agricultural production and habitat disturbance. Journal of Nematology, v.21, n.4, p.437-443, 1989.

NIBLACK, T.L.; BERNARD, E.C. Plant-parasitic nematode communities in dogwood, mapple, and peach nurseries in Tennessee. Journal of Nematology, v.17, n.2, p.132-139, 1985.

NICKLE, W.R. (Ed.). Manual of agricultural nematology. New York: Marcel Dekker, 1991, 1035p.

NILES, R.K.; FRECKMAN, D.W. From the ground up: nematode ecology in bioassessment and ecosystem health. In: BARTELS, J.M. (Ed.). Plant and nematode interactions. Madison: ASA/CSSA/SSSA, 1998. cap.4, p.65-85.

NOMBELA, G.; NAVAS, A.; BELLO, A. Nematodes as bioindicators of dry pasture recovery after temporary rye cultivation. Soil Biology and Biochemistry, v.31, n.4, p.535-541, 1999.

NORTON, B. Commodity, amenity, and morality; the limits of quantification in valuing biodiversity. In: WILSON, E. O; PETER, F. M. (Ed.). Biodiversity. Washington: National Academy Press, p.200-205, 1988.

NORTON, D.C. Communities. In: NORTON, D.C. Ecology of plant-parasitic nematodes. New York: John Wiley, p.59-79, 1978. 
NORTON, D.C.; HOFFMANN, J.K. Distribution of selected plant parasitic nematodes relative to vetetation and edaphic factors. Journal of Nematology, v.6, n.2, p.81-86, 1974.

NORTON, D.C.; NIBLACK, T.L. Biology and ecology of nematodes. In: NICKLE, W.R. (Ed.). Manual of agricultural nematology. New York: Marcel Dekker, 1991. p.47-72.

ODUM, E.P. Fundamentos da ecologia. Lisboa: Fundação Calouste Gulbenkian, 1973. 595p.

ODUM, E.P. Populações em comunidades. In: ODUM, E.P. Ecologia. Rio de Janeiro: Ed. Guanabara, 1988. p.233-281.

OLIVEIRA, J.B.; PRADO, H. Levantamento pedológico semidetalhado do Estado de São Paulo: quadrícula de São Carlos. II. Memorial Descritivo. Campinas: Instituto Agronômico, 1984. 188p. (Boletim Técnico, 98)

PANESAR, T.S.; MARSHALL, V.G.; BARCLAY, H.J. Abundance and diversity of soil nematodes in chronosequences of coastal Douglas-fir forests on Vancouver Island, British Columbia. Pedobiologia, v.45, n.3, p.193-212, 2001.

PARMELEE, R.W.; ALSTON, D.G. Nematode trophic structure in conventional and no-tillage agroecosystems. Journal of Nematology, v.18, n.3, p.403-407, 1986.

PIMENTEL GOMES, F. A estatística moderna na pesquisa agropecuária. Piracicaba: POTAFOS, 1987. 162p.

POINAR JUNIOR, G.O. The natural history of nematodes. New Jersey: Prentice-Hall, 1983. 323p. 
POPOVICI, I.; CIOBANU, M. Diversity and distribution of nematode communities in grasslands from Romania in relation to vegetation and soil characteristics. Applied Soil Ecology, v.14, n.1, p.27-36, 2000.

PORAZINSKA, D.L.; COLEMAN, D.C. Ecology of nematodes under influence of Cucurbita spp. and different fertilizer types. Journal of Nematology, v.27, n.4S, p.617-623, 1995.

PORAZINSKA, D.L.; DUNCAN, L.W.; MCSORLEY, R.; GRAHAM, J.H. Nematode communities as indicators of status and processes of a soil ecosystem influenced by agricultural management practices. Applied Soil Ecology, v.13, n.1, p.69-86, 1999.

PORAZINSKA, D.L.; MCSORLEY, R.; DUNCAN, L.W.; GALLAHER, R.N.; WHEATON, T.A.; PARSONS, L.R. Relationships between soil chemical status, soil nematode community, and sustainability indices. Nematropica, v.28, n.2, p.249-261, 1998a.

PORAZINSKA, D.L.; MCSORLEY, R.; DUNCAN, L.W.; GRAHAM, J.H.; WHEATON, T.A.; PARSONS, L.R. Nematode community composition under various irrigation schemes in a citrus soil ecosystem. Journal of Nematology, v.30, n.2, p.170-178, 1998b.

POWERS, L.E.; MCSORLEY, R. Soil nematode community structure in two tropical pastures. Nematropica, v.24, n.2, p.133-141, 1994.

POWERS, L.E.; MCSORLEY, R.; DUNN, R.A. Effects of mixed cropping on a soil nematode community in Honduras. Journal of Nematology, v.25, n.4, p.666-673, 1993. 
PRADO, C.H.B. de A. Capacidade fotossintética de algumas espécies lenhosas do cerrado sob condições de campo. São Carlos, 1994. 131p. Tese (Doutorado) Universidade Federal de São Carlos.

REAY, F; WALLACE, H.R. Plant nematodes associated with native vegetation in South Australia. Nematologica, v.27, n.3, p.319-329, 1981.

RENCO, M. Seasonal dynamics of plant parasitic and free living nematodes in sugar beet, cereals and lucerne fields in East Slovakia. Helminthologia, v.39, n.1, p.51-57, 2002.

RICKLEFS, R.E. A economia da natureza. Rio de Janeiro: Guanabara Koogan, 1996. $469 p$.

ROMANENKO, E.N.; GELTZER, J.G.; ROMANENKO, N.D. The effect of soil disturbance in a spruce forest on the abundance of nematode trophic groups. Russian Journal of Nematology, v.5, n.2, p.97-101, 1997.

RUESS, L. Nematode fauna in spruce forest soils: a qualitative/quantitative comparison. Nematologica, v.41, n.1, p.106-124, 1995.

SAMATHANAM, G.J.; CHAWLA, M.L. Community analysis of soil and plant parasitic nematodes of hilly areas of southern districts of Tamil Nadu. Indian Journal of Nematology, v.12, n.1, p.60-64, 1982.

SAVIOZZI, A.; LEVI-MINZI, R.; CARDELLI, R.; RIFFALDI, R. A comparison of soil quality in adjacent cultivated, forest and native grassland soils. Plant and Soil, v.233, n.2, p.251-259, 2001. 
SCHMITT, D.P.; NORTON, D.C. Relationships of plant parasitic nematodes to sites in native Iowa prairies. Jornal of Nematology, v.4, n.3, p.200-206, 1972.

SEASTEDT, T.R.; JAMES, S.W.; TODD, T.C. Interactions among soil invertebrates, microbes and plant growth in the tallgrass prairie. Agriculture, Ecosystems and Environment, v.24, n.1-3, p.219-228, 1998.

SHANNON, C.E.; WEAVER, W. The mathematical theory of communication. Urbana: University of Illinois Press, 1949. 117p.

SHERWOOD, S.; UPHOFF, N. Soil health: research, practice and policy for a more regenerative agriculture. Applied Soil Ecology, v.15, n. 1, p. 85-97, 2000.

SIDDIQI, M.R. Tylenchida: parasites of plants and insects. Wallingford: CABI, 2000. $833 p$.

SILVA, R.T. Influência da disponibilidade hídrica sobre as trocas gasosas em duas espécies de pteridófitas de cerrado sob condições controladas e de campo. São Carlos, 1998. 226p. Tese (Doutorado) - Universidade Federal de São Carlos.

SILVEIRA NETO, S.; NAKANO, O.; BARBIN, D.; NOVA, N.A.V. Manual de ecologia dos insetos. São Paulo: Ed. Agronômica Ceres, 1976. 419p.

SMALL, R.W. A review of the prey of predatory soil nematodes. Pedobiologia, v.30, n.3, p.179-206, 1987.

SOHLENIUS, B.; SANDOR, A. Ploughing of a perennial grass ley - effect on the nematode fauna. Pedobiologia, v.33, n.4, p.199-210, 1989. 
SOHLENIUS, B.; WASILEWSKA, L. Influence of irrigation and fertilization on the nematode community in a swedish pine forest soil. Journal of Applied Ecology, v.21, n.1, p.327-342, 1984.

SOHLENIUS, B.; BOSTRÖM, S.; SANDOR, A. Long-term dynamics of nematode communities in arable soil under four cropping systems. Journal of Applied Ecology, v.24, n.1, p.131-144, 1987.

SOUTHWOOD, T.R.E. Ecological methods. London: Methuen, 1968. 391p.

TAMBELINI, M. Germinação de sementes e crescimento inicial de três espécies da flora do cerrado. São Carlos, 1999. 131p. Tese (Doutorado) - Universidade Federal de São Carlos.

THORNE, G. Principles of nematology. New York: McGraw-Hill, 1961. 553p.

TIHOHOD, D. Guia prático de identificação de fitonematóides. Jaboticabal: FCAV; FAPESP, 1997. 246p.

TROFYMOW, J.A.; COLEMAN, D.C. The role of bacterivorous and fungivorous nematodes in cellulose and chitin decomposition in the context of a root/rhizosphere/soil conceptual model. In: FRECKMAN, D.W. (Ed.). Nematodes in soil ecosystems. Austin: University of Texas Press, 1982. p.117-138.

TROFYMOW, J.A.; MORLEY, C.R.; COLEMAN, D.C.; ANDERSON, R.V. Mineralization of cellulose in the presence of chitin and assemblages of microflora and fauna in soil. Oecologia, v.60, n.1, p.103-110, 1983. 
VALOCKÁ, B.; SABOVÁ, M. Seasonal variation of the soil nematode communities in regions polluted with acid and alkaline emissions. Helminthologia, v.35, n.3, p.147-153, 1998.

VALOCKÁ, B.; SABOVÁ, M.; RENCO, M. Soil and plant nematode communities of two types of ecosystems. Helminthologia, v.38, n.2, p.105-109, 2001.

VAN VLIET, P.C.J.; GUPTA, V.V.S.R.; ABBOTT, L.K. Soil biota and crop residue decomposition during summer and autumn in south-western Australia. Applied Soil Ecology, v. 14, n.2, p.111-124, 2000.

VERSCHOOR, B.C.; DE GOEDE, R.G.M.; DE VRIES, F.W.; BRUSSAARD, L. Changes in the composition of the plant-feeding nematode community in grasslands after cessation of fertiliser application. Applied Soil Ecology, v.17, n.1, p.1-17, 2001.

VILLENAVE, C.; BONGERS, T.; EKSCHMITT, K.; DJIBRIL, D.; CHOTTE, J.L. Changes in nematode communities following cultivation of soils after fallow periods of different length. Applied Soil Ecology, v.17, n.1, p.43-52, 2001.

VINCIGUERRA, M.T.; GIANNETTO, L. Faunistic and ecological analysis of the soil nematode community of a holm-oak woodland on Etna. Nematologia Mediterranea, v.15, n.1, p.111-127, 1987.

VINCIGUERRA, M.T.; CLAUSI, M.; ROSA, G. Analisi del popolamento nematologico di una pineta d'aleppo in Sicilia. Nematologia Mediterranea, v.23, p.49-55, 1995. Supplement. 
WALL, D.H.; ADAMS, G.; PARSONS, A.N. Soil biodiversity. In: CHAPIN III, F.S.; SALA, O.E.; HUBER-SANNWALD, E. (Ed.). Global biodiversity in a changing environment: scenarios for the 21 st century. New York: Springer-Verlag, 2001. cap.4, p.47-82.

WALL-FRECKMAN, D.; HUANG, S.P. Response of the soil nematode community in a shortgrass steppe to long-term and short-term grazing. Applied Soil Ecology, v.9, n.1/3, p.39-44, 1998.

WALLACE, H.R. Adaptation in nematodes. In: WALLACE, H.R. Nematode ecology and plant disease. London: Edward Amold, 1973. cap.7, p.116-145.

WALLWORK, J.A. Ecology of soil animals. London: McGraw-Hill, 1970. 283p.

WARDLE, D.A.; YEATES, G.W. The dual importance of competition and predation as regulatory forces in terrestrial ecosystems: evidence from decomposer food-webs. Oecologia, v.93, n.2, p.303-306, 1993.

WARDLE, D.A.; YEATES, G.W.; WATSON, R.N.; NICHOLSON, K.S. The detritus food-web and the diversity of soil fauna as indicators of disturbance regimes in agro-ecosystems. Plant and Soil, v.170, n.1, p.35-43, 1995.

WASILEWSKA, L. Soil invertebrates as bioindicators, with special reference to soil-inhabiting nematodes. Russian Journal of Nematology, v.5, n.2, p.113-126, 1997.

WHITFORD, W.G.; FRECKMAN, D.W.; SANTOS, P.F.; ELKINS, N.Z.; PARKER, L.W. The role of nematodes in decomposition in desert ecosystems. In: FRECKMAN, D.W. (Ed.). Nematodes in soil ecosystems. Austin: University of Texas Press, 1982. p.98-116. 
WILSON, E.O. Diversidade da vida. São Paulo: Companhia da Letras, 1994. 447p.

WOLTERS, V. Invertebrate control of soil organic matter stability. Biology and Fertility of Soils, v.31, n.1, p.1-19, 2000.

WRIGHT, D.J.; NEWALL, D.R. Nitrogen excretion, osmotic and ionic regulation in nematodes. In: CROLL, N.A. (Ed.). The organization of nematodes. London: Academic Press, 1976. cap.6, p.163-210.

XU, W.; MAGE, J.A. A review of concepts and criteria for assessing agroecosystem health including a preliminary case study of southern Ontario. Agriculture, Ecosystems and Environment, v.83, n.3, p.215-233, 2001.

YEATES, G.W. Soil nematodes in New Zealand pastures. Soil Science, v.123, n.6, p.415-422, 1977.

YEATES, G.W. Populations of nematode genera in soils under pasture. I. Seasonal dynamics in dryland and irrigated pastures on a southern yellow-grey earth. New Zealand Journal of Agricultural Research, v.21, n.2, p.321-330, 1978a.

YEATES, G.W. Populations of nematode genera in soils under pasture. II. Seasonal dynamics in dryland and effluent-irrigated pastures on a central yellow-grey earth. New Zealand Journal of Agricultural Research, v.21, n.2, p.331-340, 1978 b.

YEATES, G.W. Populations of nematode genera in soils under pasture. IV. Seasonal dynamics at five North Island sites. New Zealand Journal of Agricultural Research, v.24, n.1, p.107-121, 1981. 
YEATES, G.W. Impact of historical changes in land use on the soil fauna. New Zealand Journal of Ecology, v.15, n.1, p.99-106, 1991.

YEATES, G.W. Modification and qualification of the nematode maturity index. Pedobiologia, v.38, n.2, p.97-101, 1994.

YEATES, G.W. Feeding in free-living soil nematodes: a functional approach. In: PERRY, R.N.; WRIGHT, D.J. (Ed.). The phisiology and biochemistry of free-living and plant-parasitic nematodes. Wallingford: CABI, 1998. cap.10, p.245-269.

YEATES, G.W. Effects of plants on nematode community structure. Annual Review of Phytopathology, v.37, p.127-149, 1999.

YEATES, G.W.; BONGERS, T. Nematode diversity in agroecosystems. Agriculture, Ecosystems and Environment, v.74, n.1/3, p.113-135, 1999.

YEATES, G.W.; HUGHES, K.A. Effect of three tillages regimes on plant and soil nematodes in na oats/maize rotation. Pedobiologia, v.34, n.6, p.379-387, 1990.

YEATES, G.W.; KING, K.L. Soil nematodes as indicators of the effect of management on grasslands in the New England Tablelands (NSW): comparison of native and improved grasslands. Pedobiologia, v.41, n.6, p.526-536, 1997.

YEATES, G.W.; WILLIAMS, P.A. Influence of three invasive weeds and site factors on soil microfauna in New Zealand. Pedobiologia, v.45, n.4, p.367-383, 2001.

YEATES, G.W.; HAWKE, M.F.; RIJKSE, W.C. Changes in soil fauna and soil conditions under Pimus radiata agroforestry regimes during a 25-year tree rotation. Biology and Fertility of Soils, v.31, n.5, p.391-406, 2000. 
YEATES, G.W.; WARDLE, D.A.; WATSON, R.N. Relationships between nematodes, soil microbial biomass and weed-management strategies in maize and asparagus cropping systems. Soil Biology and Biochemistry, v.25, n.7, p.869-876, 1993.

YEATES, G.W.; WARDLE, D.A.; WATSON, R.N. Responses of soil nematode populations, community structure, diversity and temporal variability to agricultural intensification over a seven-year period. Soil Biology and Biochemistry, v.31, n. 12, p.1721-1733, 1999.

YEATES, G.W.; BONGERS, T.; DE GOEDE, R.G.M.; FRECKMAN, D.W.; GEORGIEVA, S.S. Feeding habits in soil nematode families and genera - an outline for soil ecologists. Journal of Nematology, v.25, n.3, p.315-331, 1993.

YEATES, G.W.; BARDGETT, R.D.; COOK, R.; HOBBS, P.J.; BOWLING, P.J.; POTTER, J.F. Faunal and microbial diversity in three Welsh grassland soils under conventional and organic management regimes. Journal of Applied Ecology, v.34, n.2, p.453-470, 1997.

YUEN, P.H. The nematode fauna of the regenerated woodland and grassland of broadbalk wilderness. Nematologica, v. 12, n.2, p.195-214, 1966.

ZAMITH, A.P.L.; LORDELLO, L.G.E. Algumas observações sobre nematódeos em solo de mata e em solo cultivado. Revista de Agricultura, v.32, n.2, p.183-188, 1957. 


\section{APÊNDICES}




\section{DADOS ORIGINAIS DE IDENTIFICAÇÕES TAXONÔMICAS E ABUNDÂNCIAS}

Tabela 1. Nematóides (gêneros ou famílias) e respectivas abundâncias (números de indivíduos por $200 \mathrm{ml}$ de solo) das amostras de solo da área de cerrado coletadas em maio de 1999.

\begin{tabular}{|c|c|c|c|c|c|c|c|c|c|c|}
\hline \multirow[t]{2}{*}{ Taxa } & \multicolumn{10}{|c|}{ Amostras } \\
\hline & 1 & 2 & 3 & 4 & 5 & 6 & 7 & 8 & 9 & 10 \\
\hline Acrobeles & 59 & - & 71 & 53 & 32 & 12 & - & - & - & - \\
\hline Acrobeloides & - & - & - & 13 & - & - & - & - & 18 & - \\
\hline Aorolaimus & - & 3 & - & - & - & - & - & 7 & - & - \\
\hline Aporcelaimellus & - & - & - & - & 3 & 54 & - & 7 & 7 & 5 \\
\hline Axonchium & 7 & - & - & - & - & - & - & - & - & - \\
\hline Basirotyleptus & 7 & 3 & - & 13 & - & 40 & - & 7 & 39 & 20 \\
\hline Cephalobidae & - & - & - & - & - & - & - & 7 & 3 & - \\
\hline Cephalobus & 7 & - & - & - & - & - & - & - & 3 & - \\
\hline Chiloplacus & - & 6 & - & - & - & - & - & - & - & - \\
\hline Chitwoodius & 7 & - & - & - & - & - & - & - & 3 & - \\
\hline Clarkus & 20 & - & - & - & 11 & - & - & - & - & - \\
\hline Cruznema & - & - & - & - & - & - & - & - & 11 & - \\
\hline Dactyluraxonchium & - & - & - & - & - & - & 19 & - & - & - \\
\hline Diphtherophora & 7 & 9 & - & 13 & 3 & 13 & - & 7 & - & 5 \\
\hline Discocriconemella & 13 & - & 10 & 96 & 63 & 350 & 20 & 11 & 96 & 44 \\
\hline Discolaimium & 7 & 9 & 12 & 9 & 6 & 40 & - & - & - & - \\
\hline Discolaimoides & 15 & 6 & 24 & 13 & - & 107 & 57 & - & 3 & - \\
\hline Ditylenchus & 7 & - & - & - & - & - & - & 7 & - & - \\
\hline Dorylaimellus & 15 & 6 & 36 & 78 & 42 & 80 & - & 22 & 21 & 20 \\
\hline Dorylaimoides & 45 & - & - & - & 44 & 13 & 19 & 15 & 18 & 5 \\
\hline Ecumenicus & - & - & - & - & - & 27 & - & - & - & - \\
\hline Enchodelus & - & - & - & - & - & 13 & - & - & - & - \\
\hline Eucephalobus & - & - & - & - & - & - & - & 15 & 18 & - \\
\hline Eudorylaimus & 22 & - & 12 & 13 & 9 & 134 & - & - & 7 & 15 \\
\hline Euteratocephalus & - & - & - & - & - & - & - & 7 & - & - \\
\hline Glochidorella & - & - & - & - & - & - & - & - & 3 & - \\
\hline Helicotylenchus & 20 & - & - & - & 21 & 48 & 20 & 11 & - & 11 \\
\hline Ironus & - & - & - & - & - & - & - & - & 7 & - \\
\hline
\end{tabular}


Tabela 1. Nematóides (gêneros ou famílias) e respectivas abundâncias (números de indivíduos por $200 \mathrm{ml}$ de solo) das amostras de solo da área de cerrado coletadas em maio de 1999.

\begin{tabular}{|c|c|c|c|c|c|c|c|c|c|c|}
\hline \multirow[t]{2}{*}{ Taxa } & \multicolumn{10}{|c|}{ Amostras } \\
\hline & $\mathbf{1}$ & 2 & 3 & 4 & 5 & 6 & 7 & 8 & 9 & 10 \\
\hline Labronema & 37 & 3 & 36 & 78 & 9 & 161 & 57 & - & - & - \\
\hline Leptonchidae & 22 & 6 & - & - & 6 & 13 & - & - & 3 & - \\
\hline Leptonchus & - & 3 & - & - & - & 27 & - & 7 & - & - \\
\hline Mesodorylaimus & 45 & - & - & - & - & - & - & - & 7 & - \\
\hline Meylis & - & - & - & - & - & - & - & - & 3 & - \\
\hline Microdorylaimus & - & 6 & - & - & 3 & 67 & - & - & 3 & 20 \\
\hline Mononchidae & 13 & - & - & - & 11 & - & - & - & - & - \\
\hline Mononchus & - & - & - & 11 & 10 & - & - & - & - & - \\
\hline Mylodiscus & - & - & - & - & - & - & - & - & 3 & - \\
\hline Nygolaimellus & 7 & - & - & 13 & 3 & 27 & - & 7 & 3 & - \\
\hline Nygolaimidae & 30 & - & - & - & 6 & - & - & - & - & - \\
\hline Opisthodorylaimus & - & - & - & - & - & 13 & - & - & - & - \\
\hline Oriverutus & 7 & - & - & - & - & 54 & - & - & 3 & - \\
\hline Paraphelenchus & - & 3 & - & - & - & - & - & - & - & - \\
\hline Paratrichodorus & - & - & - & - & - & - & - & - & - & 5 \\
\hline Paratylenchus & - & 3 & - & - & - & - & - & - & - & - \\
\hline Plectus & - & - & - & - & - & - & - & 7 & 3 & - \\
\hline Rhabditidae & - & - & - & 39 & 3 & - & 19 & 37 & 3 & - \\
\hline Rhabditis & - & - & 12 & - & - & - & - & 22 & - & - \\
\hline Sporonchulus & - & - & - & - & 10 & - & - & - & - & - \\
\hline Tylenchidae & 7 & - & - & - & - & - & 19 & - & 7 & - \\
\hline Tylencholaimellus & - & - & - & - & - & - & - & - & - & 5 \\
\hline Tylencholaimus & - & - & - & - & - & - & - & - & 11 & - \\
\hline Tylenchulus & - & 173 & - & 129 & - & 27 & 57 & 7 & 7 & - \\
\hline Tyleptus & 7 & - & - & - & - & - & - & - & - & - \\
\hline Wilsonema & - & - & - & 26 & - & - & - & - & - & - \\
\hline Xiphinema & - & 10 & - & - & - & 12 & - & - & - & - \\
\hline
\end{tabular}


Tabela 2. Nematóides (gêneros ou famílias) e respectivas abundâncias (números de indivíduos por $5 \mathrm{~g}$ de raízes) das amostras de raizes da área de cerrado, coletada em maio de 1999.

\begin{tabular}{lcccccccccc}
\hline Taxa & \multicolumn{7}{c}{ Amostras } \\
& $\mathbf{1}$ & $\mathbf{2}$ & $\mathbf{3}$ & $\mathbf{4}$ & $\mathbf{5}$ & $\mathbf{6}$ & $\mathbf{7}$ & $\mathbf{8}$ & $\mathbf{9}$ & $\mathbf{1 0}$ \\
\hline $\begin{array}{l}\text { Aphelenchus } \\
\text { Discocriconemella }\end{array}$ & - & 11 & 11 & - & - & - & 13 & - & 8 & - \\
Ditylenchus & - & - & - & - & - & - & - & - & - & 5 \\
Helicotylenchus & - & - & - & 11 & - & - & - & - & - & - \\
Paratylenchus & - & 11 & 11 & - & - & 8 & - & - & 8 & 5 \\
Pratylenchus & - & - & 32 & 23 & - & - & 13 & - & - & - \\
Tylenchidae & - & - & - & - & - & - & - & 11 & - & 16 \\
Tylenchulus & - & - & - & 11 & - & 32 & 50 & 78 & 42 & 32 \\
\hline
\end{tabular}

Tabela 3. Nematóides (gêneros ou famílias) e respectivas abundâncias (números de indivíduos por $200 \mathrm{ml}$ de solo) das amostras de solo da área de goiabal, coletada em maio de 1999.

\begin{tabular}{lcccccccccc}
\hline Taxa & \multicolumn{7}{c}{ Amostras } & & & \\
& $\mathbf{1}$ & $\mathbf{2}$ & $\mathbf{3}$ & $\mathbf{4}$ & $\mathbf{5}$ & $\mathbf{6}$ & $\mathbf{7}$ & $\mathbf{8}$ & $\mathbf{9}$ & $\mathbf{1 0}$ \\
\hline Acrobeles & 24 & 22 & 7 & 51 & $\mathbf{8}$ & 37 & 51 & 44 & 52 & 90 \\
Acrobeloides & 2 & - & - & - & - & - & - & - & - & 9 \\
Aphelenchoides & - & - & - & - & - & - & - & - & - & 9 \\
Aphelenchus & 13 & 5 & 8 & 17 & 7 & - & - & - & - & - \\
Aporcelaimellus & 5 & 5 & 12 & - & - & - & - & - & - & - \\
Axonchium & - & - & - & - & - & - & - & - & - & 9 \\
Belondira & - & - & - & - & - & 30 & - & - & - & - \\
Carcharolaimus & - & - & - & - & - & 15 & - & - & - & 9 \\
Cephalobidae & 5 & - & - & 9 & - & - & - & - & - & - \\
Cephalobus & 2 & - & - & - & 4 & - & - & - & - & - \\
Chiloplacus & - & - & 4 & - & - & - & - & - & - & - \\
Chitwoodius & - & - & 24 & 9 & 4 & - & - & 6 & 15 & - \\
Chromadoridae & 2 & - & - & - & - & - & - & - & - & - \\
Diphtherophora & 5 & 14 & 8 & 34 & - & 61 & 36 & 12 & 15 & - \\
Discolaimium & - & - & 4 & 17 & 11 & 61 & 45 & 24 & 15 & - \\
Discolaimium ou Discolaimoides & 2 & - & 4 & - & - & 15 & - & - & - & 9
\end{tabular}


Tabela 3. Nematóides (gêneros ou famílias) e respectivas abundâncias (números de indivíduos por 200ml de solo) das amostras de solo da área de goiabal, coletada em maio de 1999.

\begin{tabular}{|c|c|c|c|c|c|c|c|c|c|c|c|}
\hline \multirow[t]{2}{*}{ Taxa } & & \multicolumn{10}{|c|}{ Amostras } \\
\hline & & 1 & 2 & 3 & 4 & 5 & 6 & 7 & 8 & 9 & 10 \\
\hline Discolaimoides & & 2 & - & 8 & 9 & - & 15 & 18 & 12 & - & - \\
\hline Discolaimus & & - & - & - & 9 & - & 30 & - & - & - & - \\
\hline Ditylenchus & & - & - & - & - & - & - & - & - & - & 9 \\
\hline Dorylaimellus & & 18 & 43 & 8 & 63 & - & - & 109 & 74 & 61 & 9 \\
\hline Dorylaimoides & & - & - & - & - & - & - & - & - & 16 & - \\
\hline Eucephalobus & & - & 10 & 16 & 9 & - & 30 & - & - & 15 & - \\
\hline Eudorylaimus & & 10 & 14 & 32 & 34 & 7 & 61 & 36 & 12 & 46 & 86 \\
\hline Helicotylenchus & & 96 & 384 & 235 & 425 & 179 & 246 & 637 & 338 & 338 & 312 \\
\hline Hemicycliophora & & - & - & - & - & - & 7 & - & 18 & - & - \\
\hline Labronema & & - & - & 4 & - & 4 & - & - & - & - & - \\
\hline Leptonchidae & $\because$ & - & - & - & - & - & - & 9 & - & - & - \\
\hline Leptonchus & & - & - & - & - & - & - & - & 6 & - & - \\
\hline Mesodorylaimus & & - & - & 4 & 43 & 25 & 61 & - & 24 & 23 & 34 \\
\hline Monhystera & & - & - & - & - & - & - & - & - & 8 & - \\
\hline Mononchus & & - & - & - & - & - & - & 20 & - & - & - \\
\hline Mylonchulus & & - & 11 & 7 & 11 & - & 7 & - & 9 & 26 & 33 \\
\hline Nygolaimus & & 10 & - & - & - & - & - & - & - & - & - \\
\hline Opisthodorylaimus & & 10 & 5 & 28 & 69 & 7 & - & - & - & - & 9 \\
\hline Panagrolaimus & & 2 & - & - & - & - & - & - & - & - & - \\
\hline Paraphelenchus & & 2 & - & - & - & - & - & - & - & - & - \\
\hline Paratrichodorus & & - & - & - & - & - & - & 9 & 12 & - & - \\
\hline Plectus & & - & 5 & - & - & - & - & - & - & - & - \\
\hline Prismatolaimus & & - & 5 & - & - & - & 30 & - & - & 23 & 9 \\
\hline Qudsianematidae & & - & 29 & - & 9 & - & - & 9 & - & - & 9 \\
\hline Rhabditidae & & 18 & - & 28 & 17 & 25 & 30 & - & 6 & 8 & 17 \\
\hline Rhabditis & & 5 & - & - & - & - & 137 & 18 & 6 & 38 & 95 \\
\hline
\end{tabular}


Tabela 3. Nematóides (gêneros ou famílias) e respectivas abundâncias (números de indivíduos por 200ml de solo) das amostras de solo da área de goiabal, coletada em maio de 1999.

\begin{tabular}{lcccccccccc}
\hline Taxa & \multicolumn{7}{c}{ Amostras } \\
& $\mathbf{1}$ & $\mathbf{2}$ & $\mathbf{3}$ & $\mathbf{4}$ & $\mathbf{5}$ & $\mathbf{6}$ & $\mathbf{7}$ & $\mathbf{8}$ & $\mathbf{9}$ & $\mathbf{1 0}$ \\
\hline Tylenchidae & 16 & 19 & $\mathbf{8}$ & 26 & - & 30 & - & - & 8 & 17 \\
Tylencholaimellus & - & - & - & - & - & - & - & - & 8 & - \\
Wilsonema & 2 & - & - & - & - & - & - & - & - & 9 \\
Xiphinema & - & - & - & 11 & - & 43 & 10 & 9 & 43 & 82 \\
Zeldia & - & - & 8 & - & - & - & - & - & 8 & - \\
\hline
\end{tabular}

Tabela 4. Nematóides (gêneros ou famílias) e respectivas abundâncias (números de indivíduos por $5 \mathrm{~g}$ de raízes) das amostras de raizes da área de goiabal, coletada em maio de 1999.

\begin{tabular}{lcccccccccc}
\hline Taxa & \multicolumn{1}{c}{ Amostras } & & & \\
& $\mathbf{1}$ & $\mathbf{2}$ & $\mathbf{3}$ & $\mathbf{4}$ & $\mathbf{5}$ & $\mathbf{6}$ & $\mathbf{7}$ & $\mathbf{8}$ & $\mathbf{9}$ & $\mathbf{1 0}$ \\
\hline Aphelenchus & $\mathbf{8}$ & $\mathbf{9}$ & - & - & - & - & - & - & - & - \\
Helicotylenchus & 144 & 18 & 16 & 9 & 16 & 46 & 64 & 11 & 36 & 47 \\
Pratylenchus & 24 & 9 & 24 & 17 & 8 & - & 40 & 22 & 12 & 19 \\
Tylenchidae & 24 & - & 16 & - & - & 31 & - & 11 & 24 & - \\
\hline
\end{tabular}

Tabela 5. Nematóides (gêneros ou famílias) e respectivas abundâncias (números de indivíduos por $200 \mathrm{ml}$ de solo) das amostras de solo da área de milharal, coletada em maio de 1999.

\begin{tabular}{lcccccccccc}
\hline Taxa & \multicolumn{1}{c}{ Amostras } & \multicolumn{1}{c}{} & & \\
& $\mathbf{1}$ & $\mathbf{2}$ & $\mathbf{3}$ & $\mathbf{4}$ & $\mathbf{5}$ & $\mathbf{6}$ & $\mathbf{7}$ & $\mathbf{8}$ & $\mathbf{9}$ & $\mathbf{1 0}$ \\
\hline Achromadora & - & - & - & - & - & - & - & - & 23 & - \\
Acrobeles & 39 & 40 & 70 & 30 & 109 & 141 & 244 & 71 & 119 & 51 \\
Amphidorylaimus & - & - & - & - & - & - & 18 & 14 & - & - \\
Aphelenchoides & 13 & - & - & - & - & 22 & - & - & - & - \\
Aphelenchus & 52 & 17 & - & - & 34 & 22 & 18 & - & - & 22 \\
Aporcelaimellus & - & 8 & 31 & 29 & 102 & 131 & 18 & 149 & 182 & 43 \\
Aporcelaimidae & 13 & 34 & - & 29 & - & - & - & - & - & - \\
Axonchium & - & - & - & 29 & - & - & - & - & - & - \\
Carcharolaimus & - & 8 & 15 & - & - & - & - & - & - & 22 \\
Cephalobidae & 13 & - & - & - & - & 22 & 18 & 27 & - & -
\end{tabular}


Tabela 5. Nematóides (gêneros ou familias) e respectivas abundâncias (números de indivíduos por $200 \mathrm{ml}$ de solo) das amostras de solo da área de milharal, coletada em maio de 1999.

\begin{tabular}{|c|c|c|c|c|c|c|c|c|c|c|}
\hline \multirow[t]{2}{*}{ Taxa } & \multicolumn{10}{|c|}{ Amostras } \\
\hline & 1 & 2 & 3 & 4 & 5 & 6 & 7 & 8 & 9 & 10 \\
\hline Chiloplacus & - & - & - & - & - & - & - & - & 23 & - \\
\hline Chitwoodius & - & 51 & 15 & 201 & 34 & 22 & 18 & 14 & - & 22 \\
\hline Criconemella & - & - & - & - & - & - & - & 10 & - & - \\
\hline Diphtherophora & 10 & 51 & 15 & 57 & 34 & 22 & 36 & - & - & - \\
\hline Discolaimium & 53 & 8 & 15 & 144 & - & 44 & 36 & 14 & - & - \\
\hline Discolaimium ou Discolaimoides & 13 & 8 & - & - & - & - & - & - & - & - \\
\hline Discolaimoides & - & 8 & 15 & - & 34 & 22 & - & - & - & 22 \\
\hline Discolaimus & - & - & - & - & - & - & - & 14 & 68 & - \\
\hline Ditylenchus & 39 & - & - & - & - & - & 18 & - & - & - \\
\hline Dorylaimidae & - & - & - & - & - & - & 18 & - & - & - \\
\hline Dorylaimellus & - & - & - & - & - & - & - & - & 23 & - \\
\hline Ecumenicus & - & - & 15 & - & - & - & - & - & - & - \\
\hline Eucephalobus & 31 & 34 & - & 29 & - & 44 & 108 & 41 & - & 22 \\
\hline Eudorylaimus & 25 & 25 & 76 & 144 & 169 & 22 & 162 & 68 & 204 & 195 \\
\hline Helicotylenchus & 1052 & 191 & 789 & 674 & 1067 & 988 & 102 & 183 & 71 & 355 \\
\hline Mesodorylaimus & 37 & 34 & 30 & 172 & 102 & 22 & 126 & 14 & 23 & - \\
\hline Mesorhabditis & - & - & - & - & - & - & - & - & 23 & - \\
\hline Monhystera & - & 13 & - & - & - & - & 18 & - & - & - \\
\hline Mononchus & - & - & - & 10 & - & 20 & - & - & - & - \\
\hline Mylonchulus & 13 & - & 26 & 40 & 9 & - & 30 & 30 & - & 10 \\
\hline Nygolaimellus & - & 8 & 30 & - & 34 & 22 & 18 & 14 & 68 & 239 \\
\hline Opisthodorylaimus & 37 & 34 & 137 & 115 & 203 & 22 & 144 & 68 & 91 & 239 \\
\hline Panagrolaimus & - & 17 & 15 & - & 34 & - & - & - & - & - \\
\hline Paraphelenchus & - & 5 & - & - & 34 & - & - & - & - & - \\
\hline Plectidae & - & - & - & - & - & - & - & 14 & - & - \\
\hline Plectus & 86 & 42 & 15 & 29 & 68 & 22 & 18 & 14 & - & - \\
\hline Pratylenchus & 13 & 91 & 70 & 91 & 173 & 423 & 488 & 529 & 1165 & 670 \\
\hline Prionchulus & - & - & 9 & - & - & - & - & 20 & - & 30 \\
\hline Prismatolaimus & 7 & 8 & - & - & - & - & - & - & - & - \\
\hline Rhabditidae & 39 & 8 & - & - & 34 & - & 18 & - & 23 & - \\
\hline
\end{tabular}


Tabela 5. Nematóides (gêneros ou famílias) e respectivas abundâncias (números de indivíduos por 200ml de solo) das amostras de solo da área de milharal, coletada em maio de 1999.

\begin{tabular}{lcccccccccc}
\hline Taxa & \multicolumn{1}{c}{ Amostras } \\
& $\mathbf{1}$ & $\mathbf{2}$ & $\mathbf{3}$ & $\mathbf{4}$ & $\mathbf{5}$ & $\mathbf{6}$ & $\mathbf{7}$ & $\mathbf{8}$ & $\mathbf{9}$ & $\mathbf{1 0}$ \\
\hline Rhabditis & 12 & 5 & - & - & - & 44 & 18 & - & 23 & - \\
Sporonchulus & - & - & - & 10 & - & - & 20 & - & - & 30 \\
Tylenchidae & 44 & 71 & 79 & 20 & 128 & 60 & - & - & 36 & 142 \\
Tylencholaimus & - & - & - & 29 & - & - & - & - & - & - \\
Xiphinema & 13 & 30 & 35 & 20 & 82 & 30 & - & - & 24 & 20 \\
Zeldia & 13 & $\mathbf{8}$ & - & - & - & 22 & 18 & 54 & 91 & 43 \\
\hline
\end{tabular}

Tabela 6. Nematóides (gêneros ou famílias) e respectivas abundâncias (números de indivíduos por $5 \mathrm{~g}$ de raízes) das amostras de raízes da área de milharal, coletada em maio de 1999.

\begin{tabular}{lcccccccccc}
\hline Taxa & \multicolumn{1}{c}{ Amostras } \\
& $\mathbf{1}$ & $\mathbf{2}$ & $\mathbf{3}$ & $\mathbf{4}$ & $\mathbf{5}$ & $\mathbf{6}$ & $\mathbf{7}$ & $\mathbf{8}$ & $\mathbf{9}$ & $\mathbf{1 0}$ \\
\hline Aphelenchoides & 61 & 21 & 30 & 10 & 41 & 72 & 41 & 52 & 10 & 31 \\
Aphelenchus & - & - & - & 20 & - & - & - & - & - & - \\
Helicotylenchus & 306 & 115 & 60 & 90 & 72 & 83 & 10 & 31 & - & 10 \\
Pratylenchus & 183 & 577 & 403 & 843 & 195 & 1719 & 645 & 2568 & 1524 & 1421 \\
Tylenchidae & 61 & 63 & 50 & 10 & 20 & 21 & 10 & 10 & 20 & 31 \\
\hline
\end{tabular}

Tabela 7. Nematóides (gêneros ou famílias) e respectivas abundâncias (números de indivíduos por $200 \mathrm{ml}$ de solo) das amostras de solo da área de cerrado, coletada em fevereiro de 2000.

\begin{tabular}{lcccccccccc}
\hline Taxa & \multicolumn{1}{c}{ Amostras } & \multicolumn{1}{c}{} \\
& $\mathbf{1}$ & $\mathbf{2}$ & $\mathbf{3}$ & $\mathbf{4}$ & $\mathbf{5}$ & $\mathbf{6}$ & $\mathbf{7}$ & $\mathbf{8}$ & $\mathbf{9}$ & $\mathbf{1 0}$ \\
\hline Acrobeles & 17 & 17 & 43 & 24 & 35 & 23 & 35 & 20 & $\mathbf{8}$ & 61 \\
Acrobeloides & 20 & $\mathbf{7}$ & - & - & - & 2 & - & 2 & - & - \\
Alaimus & 7 & 10 & 7 & 13 & - & 4 & 14 & 4 & 3 & 6 \\
Aporcelaimellus & 13 & 24 & - & 13 & 4 & 4 & 14 & 4 & 17 & 13 \\
Axonchium & 7 & 3 & - & - & 4 & - & - & - & 3 & - \\
Basirotyleptus & 13 & - & - & 4 & 9 & 8 & 4 & - & - & - \\
Cephalobidae & 7 & 3 & - & 4 & - & - & 4 & - & - & - \\
Cephalobus & - & - & - & 9 & - & 2 & - & - & - & -
\end{tabular}


Tabela 7. Nematóides (gêneros ou famílias) e respectivas abundâncias (números de indivíduos por $200 \mathrm{ml}$ de solo) das amostras de solo da área de cerrado, coletada em fevereiro de 2000.

\begin{tabular}{|c|c|c|c|c|c|c|c|c|c|c|}
\hline \multirow[t]{2}{*}{ Taxa } & \multicolumn{10}{|c|}{ Amostras } \\
\hline & 1 & 2 & 3 & 4 & 5 & 6 & 7 & 8 & 9 & 10 \\
\hline Chiloplacus & - & 3 & - & - & - & - & - & - & - & - \\
\hline Chitwoodius & - & - & - & - & 4 & 2 & - & - & - & - \\
\hline Clarkus & - & - & - & - & 14 & - & - & - & - & - \\
\hline Criconemella & - & 17 & - & - & - & - & - & 61 & - & 83 \\
\hline Cruznema & 7 & 7 & 4 & - & - & - & - & 2 & - & - \\
\hline Dactyluraxonchium & - & - & - & - & - & 2 & - & - & - & - \\
\hline Diphtherophora & - & 7 & - & - & - & - & 4 & - & - & - \\
\hline Discocriconemella & 166 & - & 43 & 71 & 142 & 45 & 135 & - & 144 & - \\
\hline Discolaimium & 7 & 17 & 11 & 18 & 36 & - & 14 & - & 23 & 6 \\
\hline Discolaimoides & 13 & 10 & 7 & 9 & 4 & - & 7 & 7 & 3 & 6 \\
\hline Dorylaimellus & 33 & 7 & 4 & 18 & - & 2 & 4 & - & 3 & - \\
\hline Dorylaimoides & - & 17 & 7 & 13 & - & 6 & 4 & 4 & 11 & 32 \\
\hline Ecumenicus & - & - & 7 & - & 23 & 10 & 14 & 7 & - & 19 \\
\hline Enchodelus & - & - & - & 18 & - & - & - & 2 & - & - \\
\hline Eucephalobus & 7 & - & 4 & 18 & - & 2 & - & - & - & - \\
\hline Eudorylaimus & - & 10 & 7 & 22 & 18 & 17 & 40 & 11 & 17 & 52 \\
\hline Helicotylenchus & - & - & 34 & - & - & - & 7 & 34 & - & - \\
\hline Hemicriconemoides & - & - & - & - & - & - & - & - & - & 83 \\
\hline Hoplolaimus & - & - & - & - & - & - & - & - & - & 6 \\
\hline Ironus & - & - & - & 4 & - & - & - & - & - & - \\
\hline Labronema & 20 & 10 & 4 & 53 & 4 & 8 & 22 & 2 & 9 & 58 \\
\hline Leptonchidae & - & 3 & 7 & - & 4 & 2 & - & - & - & 6 \\
\hline Leptonchus & 20 & - & - & - & 4 & 4 & - & - & - & - \\
\hline Mesodorylaimus & 7 & 7 & - & 4 & 104 & 8 & - & 16 & 3 & 13 \\
\hline Meylis & 26 & - & - & - & - & - & - & - & - & - \\
\hline Microdorylaimus & 26 & 14 & - & 4 & - & 4 & - & 2 & 3 & - \\
\hline Mononchidae & - & - & - & - & - & - & - & 7 & - & - \\
\hline Mylodiscus & - & 3 & - & - & - & - & - & - & 3 & - \\
\hline Mylonchulus & - & - & - & 12 & - & - & - & - & - & - \\
\hline Nygolaimellus & - & 7 & - & - & - & - & - & - & - & - \\
\hline
\end{tabular}


Tabela 7. Nematóides (gêneros ou famílias) e respectivas abundâncias (números de indivíduos por $200 \mathrm{ml}$ de solo) das amostras de solo da área de cerrado, coletada em fevereiro de 2000.

\begin{tabular}{|c|c|c|c|c|c|c|c|c|c|c|}
\hline \multirow[t]{2}{*}{ Taxa } & \multicolumn{10}{|c|}{ Amostras } \\
\hline & 1 & 2 & 3 & 4 & 5 & 6 & 7 & 8 & 9 & 10 \\
\hline Nygolaimidae & - & 3 & 7 & - & - & - & - & - & - & - \\
\hline Opisthodorylaimus & 7 & - & - & - & - & - & - & - & - & - \\
\hline Oriverutus & - & - & 4 & 4 & 9 & 2 & - & - & - & - \\
\hline Prionchulus & - & - & - & - & - & - & 7 & 7 & - & - \\
\hline Prismatolaimus & 7 & 3 & 4 & - & - & - & - & - & - & - \\
\hline Rhabditidae & 7 & 7 & 15 & - & - & - & 29 & 13 & - & 19 \\
\hline Rhabditis & - & - & - & - & - & - & - & 2 & - & - \\
\hline Sporonchulus & - & - & - & - & 14 & 11 & - & - & - & - \\
\hline Tylenchidae & - & 3 & - & 4 & - & - & - & - & - & - \\
\hline Tylencholaimellus & - & - & - & - & - & - & - & 4 & - & - \\
\hline Tylencholaimidae & - & - & - & - & 4 & - & - & 2 & - & - \\
\hline Tylencholaimus & 7 & 3 & - & - & 4 & 2 & - & - & - & 6 \\
\hline Tylenchulus & - & - & 11 & 9 & - & 2 & - & - & - & - \\
\hline Tyleptus & - & - & - & - & - & - & 4 & - & - & - \\
\hline Xiphinema & - & 8 & - & - & 7 & 11 & - & 7 & - & 9 \\
\hline
\end{tabular}

Tabela 8. Nematóides (gêneros ou famílias) e respectivas abundâncias (números de indivíduos por $5 \mathrm{~g}$ de raízes) das amostras de raízes da área de cerrado, coletada em fevereiro de 2000.

\begin{tabular}{lcccccccccc}
\hline Taxa & \multicolumn{7}{c}{ Amostras } \\
& $\mathbf{1}$ & $\mathbf{2}$ & $\mathbf{3}$ & $\mathbf{4}$ & $\mathbf{5}$ & $\mathbf{6}$ & $\mathbf{7}$ & $\mathbf{8}$ & $\mathbf{9}$ & $\mathbf{1 0}$ \\
\hline Aphelenchus & - & - & - & 9 & - & - & - & - & 8 & - \\
Discocriconemella & 20 & - & 8 & 17 & - & - & 9 & - & 8 & 21 \\
Helicotylenchus & 8 & 5 & - & - & - & 16 & - & 5 & - & 5 \\
Paratylenchus & - & - & - & - & - & 32 & - & - & - & - \\
Pratylenchus & - & - & 55 & - & 7 & - & - & - & - & - \\
Tylenchidae & 12 & 79 & - & 26 & - & 16 & - & - & 8 & 10 \\
Tylenchulus & 4 & 11 & 8 & - & - & - & 9 & 10 & 8 & 5 \\
Xiphinema & - & - & - & 9 & - & - & - & - & - & - \\
\hline
\end{tabular}


Tabela 9. Nematóides (gêneros ou famílias) e respectivas abundâncias (números de indivíduos por $200 \mathrm{ml}$ de solo) das amostras de solo da área de goiabal, coletada em fevereiro de 2000.

\begin{tabular}{|c|c|c|c|c|c|c|c|c|c|c|}
\hline \multirow[t]{2}{*}{ Taxa } & \multicolumn{10}{|c|}{ Amostras } \\
\hline & 1 & 2 & 3 & 4 & 5 & 6 & 7 & 8 & 9 & 10 \\
\hline Acrobeles & 39 & 30 & 11 & 19 & 27 & 29 & 24 & - & 83 & 42 \\
\hline Acrobeloides & 8 & - & 3 & - & - & 8 & 9 & - & 7 & 21 \\
\hline Alaimus & - & - & - & - & 40 & 3 & - & - & 7 & - \\
\hline Aphelenchus & 8 & - & 5 & - & - & 8 & - & - & 7 & - \\
\hline Aporcelaimellus & - & 9 & - & - & - & 8 & - & - & - & 5 \\
\hline Axonchium & - & - & 3 & - & - & - & - & - & - & - \\
\hline Carchärolaimus & - & - & 3 & 6 & 13 & - & - & - & 14 & - \\
\hline Cephalobus & - & - & - & - & - & 13 & 9 & - & - & - \\
\hline Chiloplacus & - & - & - & - & - & 3 & - & - & - & - \\
\hline Chitwoodius & - & - & 5 & 6 & - & - & - & - & - & - \\
\hline Chronogaster & - & - & - & - & - & 3 & - & - & - & - \\
\hline Criconemella & - & - & 3 & - & - & - & - & - & - & - \\
\hline Diphtherophora & 62 & - & 8 & 12 & - & 29 & 46 & 3 & 20 & 78 \\
\hline Discolaimium & 8 & - & 14 & - & 27 & - & 18 & 7 & 7 & 31 \\
\hline Discolaimium ou Discolaimoides & - & - & - & - & - & - & - & 3 & 7 & 5 \\
\hline Discolaimoides & 8 & - & 11 & 12 & - & - & - & 17 & - & - \\
\hline Discolaimus & - & - & - & - & - & 3 & - & - & 20 & - \\
\hline Ditylenchus & - & - & - & - & - & - & - & - & - & 5 \\
\hline Dorylaimellus & - & 4 & - & - & - & 26 & 28 & - & - & - \\
\hline Dorylaimoides & - & 4 & - & - & - & 26 & 9 & - & 80 & 26 \\
\hline Enchodelus & - & - & - & - & - & - & - & - & - & 5 \\
\hline Eucephalobus & 8 & - & 3 & - & - & - & 18 & - & - & - \\
\hline Eudorylaimus & 8 & - & 3 & - & 13 & 3 & - & 3 & - & 5 \\
\hline Helicotylenchus & 451 & 50 & 155 & 29 & 107 & 29 & 144 & 195 & 260 & 104 \\
\hline Hemicycliophora & - & - & - & - & 27 & - & 180 & - & - & - \\
\hline Labronema & 8 & 4 & 14 & 6 & - & 5 & 18 & 3 & 7 & 10 \\
\hline Leptonchidae & - & - & - & - & - & - & - & - & - & 5 \\
\hline Leptonchus & - & - & 3 & - & - & - & - & - & 7 & - \\
\hline Longidorella & - & - & 8 & - & - & - & - & 3 & - & - \\
\hline Mesodorylaimus & - & - & - & - & - & 5 & 9 & - & 7 & - \\
\hline
\end{tabular}


Tabela 9. Nematóides (gêneros ou famílias) e respectivas abundâncias (números de indivíduos por $200 \mathrm{ml}$ de solo) das amostras de solo da área de goiabal, coletada em fevereiro de 2000.

\begin{tabular}{|c|c|c|c|c|c|c|c|c|c|c|}
\hline \multirow[t]{2}{*}{ Taxa } & \multicolumn{10}{|c|}{ Amostras } \\
\hline & 1 & 2 & 3 & 4 & 5 & 6 & 7 & 8 & 9 & 10 \\
\hline Mononchus & - & - & - & - & - & - & - & - & 10 & - \\
\hline Microdorylaimus & 8 & - & - & - & - & 5 & 9 & - & - & - \\
\hline Mydonomidae & - & - & 3 & - & - & - & - & - & - & - \\
\hline Nordiidae & - & - & - & - & - & - & - & - & - & 5 \\
\hline Nygolaimus & - & - & - & - & - & - & - & - & - & 5 \\
\hline Odontolaimus & - & - & - & - & - & - & - & - & - & 5 \\
\hline Opisthodorylaimus & 15 & - & - & - & - & 3 & - & 17 & 14 & 10 \\
\hline Oriverutus & - & - & - & - & - & - & - & - & - & 26 \\
\hline Panagrolaimus & - & - & - & - & - & - & - & - & - & 5 \\
\hline Paractinolaimus & - & - & - & - & - & - & - & - & - & 10 \\
\hline Paratrichodorus & 77 & 4 & - & - & 13 & 16 & - & 20 & 20 & 5 \\
\hline Plectidae & 8 & - & - & - & - & - & - & - & - & - \\
\hline Plectus & - & - & - & - & - & 3 & - & - & - & - \\
\hline Prismatolaimus & - & - & - & - & - & 3 & 9 & - & - & - \\
\hline Qudsianematidae & - & - & - & - & - & - & 9 & - & 7 & - \\
\hline Rhabditidae & 15 & 14 & 5 & 6 & - & 5 & - & 20 & 40 & 16 \\
\hline Rhabditis & 23 & 4 & 19 & - & 13 & 16 & - & 3 & 20 & 21 \\
\hline Tylenchidae & 23 & 4 & 14 & - & - & - & - & - & 7 & 47 \\
\hline Xiphinema & - & 10 & - & - & 7 & - & 383 & 29 & 21 & 21 \\
\hline
\end{tabular}

Tabela 10. Nematóides (gêneros ou famílias) e respectivas abundâncias (números de indivíduos por $5 \mathrm{~g}$ de raízes) das amostras de raízes da área de goiabal, coletada em fevereiro de 2000.

\begin{tabular}{lcccccccccc}
\hline Taxa & \multicolumn{10}{c}{ Amostras } \\
& $\mathbf{1}$ & $\mathbf{2}$ & $\mathbf{3}$ & $\mathbf{4}$ & $\mathbf{5}$ & $\mathbf{6}$ & $\mathbf{7}$ & $\mathbf{8}$ & $\mathbf{9}$ & $\mathbf{1 0}$ \\
\hline Helicotylenchus & 12 & - & $\mathbf{7 5}$ & $\mathbf{7 0}$ & $\mathbf{1 1}$ & - & - & 21 & 24 & 12 \\
Pratylenchus & 12 & 12 & 25 & 50 & - & 11 & 15 & 42 & 24 & 49 \\
Tylenchidae & - & - & 12 & 20 & 11 & 33 & 15 & 10 & 8 & 24 \\
\hline
\end{tabular}


Tabela 11. Nematóides (gêneros ou famílias) e respectivas abundâncias (números de indivíduos por $200 \mathrm{ml}$ de solo) das amostras de solo da área de milharal, coletada em fevereiro de 2000.

\begin{tabular}{|c|c|c|c|c|c|c|c|c|c|c|}
\hline \multirow[t]{2}{*}{ Taxa } & \multicolumn{10}{|c|}{ Amostras } \\
\hline & 1 & 2 & 3 & 4 & 5 & 6 & 7 & 8 & 9 & 10 \\
\hline Achromadora & - & 2 & - & - & - & - & - & - & - & - \\
\hline Acrobeles & - & - & - & 30 & - & 83 & 19 & 11 & 39 & 21 \\
\hline Acrobeloides & - & - & - & - & - & - & - & - & - & 8 \\
\hline Amphidorylaimus & - & 3 & 2 & - & - & - & - & - & - & - \\
\hline Aphelenchoides & - & 6 & 2 & - & - & 5 & 23 & 4 & - & - \\
\hline Aphelenchus & 23 & 6 & - & - & - & - & - & 18 & 34 & 8 \\
\hline Aporcelaimidae & - & - & - & - & 3 & - & - & - & 5 & - \\
\hline Cephalobidae & - & - & - & - & - & 2 & - & - & - & - \\
\hline Cephalobus & - & - & - & - & - & 17 & 8 & - & 29 & 8 \\
\hline Chiloplacus & - & - & - & - & - & - & 4 & - & - & - \\
\hline Chitwoodius & - & 3 & 11 & - & 6 & 12 & 35 & 36 & 63 & 107 \\
\hline Diphtherophora & 2 & 2 & 2 & - & - & 14 & 15 & 25 & 34 & 38 \\
\hline Discolaimium & - & - & - & - & - & 2 & - & - & - & - \\
\hline Discolaimoides & - & - & - & - & - & 2 & - & - & - & - \\
\hline Discolaimus & - & - & 2 & - & - & - & - & - & - & - \\
\hline Ditylenchus & - & - & - & - & - & - & 4 & 4 & 14 & 69 \\
\hline Dorylaimellus & - & - & - & - & 3 & - & - & - & - & - \\
\hline Dorylaimus & - & - & 2 & - & - & - & - & - & - & - \\
\hline Eucephalobus & 2 & 9 & 11 & - & 6 & 2 & 8 & 25 & 24 & 8 \\
\hline Eudorylaimus & 2 & 3 & 4 & - & - & 5 & 4 & 4 & - & - \\
\hline Helicotylenchus & 80 & 122 & 20 & 41 & 21 & 83 & 127 & 117 & 32 & 346 \\
\hline Ironus & - & - & - & - & - & - & - & 4 & - & - \\
\hline Leptonchidae & - & - & - & - & - & - & 4 & - & - & - \\
\hline Mesodorylaimus & 11 & 18 & 24 & 20 & 28 & - & - & - & - & - \\
\hline Mesorhabditis & - & - & - & - & - & - & - & 4 & - & 8 \\
\hline Mononchidae & - & - & - & - & - & - & 6 & - & - & - \\
\hline Mylonchulus & - & - & - & - & - & - & 6 & - & - & - \\
\hline Nygolaimellus & - & - & - & - & 3 & - & - & - & - & - \\
\hline Opisthodorylaimus & 2 & 25 & 6 & - & - & 7 & 26 & 7 & 5 & 15 \\
\hline Panagrolaimus & - & 3 & - & - & 3 & 5 & 8 & - & - & - \\
\hline
\end{tabular}


Tabela 11. Nematóides (gêneros ou familias) e respectivas abundâncias (números de indivíduos por $200 \mathrm{ml}$ de solo) das amostras de solo da área de milharal, coletada em fevereiro de 2000.

\begin{tabular}{lcccccccccc}
\hline Taxa & \multicolumn{7}{c}{ Amostras } & & & \\
& $\mathbf{1}$ & $\mathbf{2}$ & $\mathbf{3}$ & $\mathbf{4}$ & $\mathbf{5}$ & $\mathbf{6}$ & $\mathbf{7}$ & $\mathbf{8}$ & $\mathbf{9}$ & 10 \\
\hline Paractinolaimus & - & - & 4 & - & - & - & - & - & - & - \\
Paraphelenchus & - & - & - & - & - & - & - & 4 & - & - \\
Paratrichodorus & 15 & 40 & 20 & - & 10 & 15 & 19 & 32 & 19 & 42 \\
Plectidae & - & 3 & - & - & - & - & - & - & - & - \\
Plectus & - & - & 4 & - & 3 & - & - & - & 10 & 8 \\
Prionchulus & - & - & - & - & - & 15 & - & - & 6 & - \\
Prismatolaimus & - & - & - & - & - & 2 & 4 & 11 & 29 & 8 \\
Rhabditidae & - & 12 & 6 & - & 6 & - & - & 4 & 10 & - \\
Rhabditis & - & 4 & 2 & - & - & 2 & 4 & 4 & - & 38 \\
Sporonchulus & - & - & - & - & - & 7 & - & 11 & - & - \\
Tylenchidae & 2 & 18 & - & 20 & 8 & 12 & 23 & 25 & 34 & 76 \\
Zeldia & - & 9 & 4 & - & - & 7 & 4 & 14 & 24 & 39 \\
\hline
\end{tabular}

Tabela 12. Nematóides (gêneros ou famílias) e respectivas abundâncias (números de indivíduos por $5 \mathrm{~g}$ de raízes) das amostras de raízes da área de milharal, coletada em fevereiro de 2000.

\begin{tabular}{lcccccccccc}
\hline Taxa & \multicolumn{1}{c}{ Amostras } \\
& $\mathbf{1}$ & $\mathbf{2}$ & $\mathbf{3}$ & $\mathbf{4}$ & $\mathbf{5}$ & $\mathbf{6}$ & $\mathbf{7}$ & $\mathbf{8}$ & $\mathbf{9}$ & $\mathbf{1 0}$ \\
\hline Aphelenchoides & 10 & - & 7 & 83 & 10 & - & - & 42 & 21 & 22 \\
Helicotylenchus & 31 & 91 & 22 & 94 & 83 & 82 & 51 & 21 & 10 & 22 \\
Pratylenchus & 10 & 13 & - & 10 & 31 & 123 & 153 & 42 & 21 & 44 \\
Tylenchidae & 21 & - & - & - & - & 31 & 20 & - & 10 & 11 \\
\hline
\end{tabular}

